\title{
Watershed - A Transdisciplinary Social Design Process Applied to an Environmental Issue
}

\author{
Forrest Thomas Conroy \\ West Virginia University
}

Follow this and additional works at: https://researchrepository.wvu.edu/etd

\section{Recommended Citation}

Conroy, Forrest Thomas, "Watershed - A Transdisciplinary Social Design Process Applied to an Environmental Issue" (2014). Graduate Theses, Dissertations, and Problem Reports. 297.

https://researchrepository.wvu.edu/etd/297

This Thesis is protected by copyright and/or related rights. It has been brought to you by the The Research Repository @ WVU with permission from the rights-holder(s). You are free to use this Thesis in any way that is permitted by the copyright and related rights legislation that applies to your use. For other uses you must obtain permission from the rights-holder(s) directly, unless additional rights are indicated by a Creative Commons license in the record and/ or on the work itself. This Thesis has been accepted for inclusion in WVU Graduate Theses, Dissertations, and Problem Reports collection by an authorized administrator of The Research Repository @ WVU. For more information, please contact researchrepository@mail.wvu.edu. 


\title{
Watershed - A Transdisciplinary Social Design Process Applied to an Environmental Issue
}

\section{Forrest Thomas Conroy}

\author{
Thesis submitted to the \\ College of Creative Arts \\ West Virginia University \\ in partial fulfillment of the \\ requirements for \\ the degree of \\ Master of Fine Arts \\ in \\ Art \& Design \\ Eve Faulkes, M.F.A., Chair
Joseph Galbreath, M.F.A. \\ Gerald Habarth, M.F.A. \\ Kofi Opoku, M.F.A.
}

Department of Graphic Design

Morgantown, West Virginia 2014

Key Words: transdisciplinary, design, Deckers Creek, human-centered design, design for social impact, environmental impact, immersive experience, watershed pollution, CreekDog 


\section{ABSTRACT}

\section{Watershed - A Transdisciplinary Social Design Process Applied to an Environmental Issue \\ Forrest Thomas Conroy}

Wicked problems are often vast, complex, and difficult to navigate. Often used in dealing with social design issues, the term "wicked" is intended to connote a problem that is difficult to define and solve rather than its moral implications. ${ }^{1}$ These problems, like watershed maintenance and pollution mitigation, involve an entwined community of diverse players, intricate systems, and everchanging terrain. Because of their pluralistic nature, these problems can seem impossible to solve and even impossible to understand. This requires a collective approach and new ways of thinking to create better understanding and solutions. Important changes occur when citizens are knowledgeable, see their connection to the whole, and feel empowered to take action.

As the problems facing society grow more complex, designers have evolved to find applications for the design process across a variety of disciplines. A transdisciplinary approach allows for a communitybased model that creates solutions to complex problems based on strategic outcomes rather than product development. This approach uses a system of solutions working together to address problems that are multi-dimensional. Historically, graphic designers are often tasked with creating a call to action. The failure in this approach is that it leaves the responsibility of that action with the audience. As designers, we should not only ask for action but facilitate action in ways that empower our audience. It is critical that we provide a context to educate our audience so they better understand the issue and develop a better attitude to take effective action.
My thesis focuses on the complex pollution issues that threaten the health of the Deckers Creek Watershed. Deckers Creek is a tributary of the Monongahela River. It flows west towards Morgantown from Arthurdale, West Virginia. Deckers Creek is a scenic waterway that has suffered a long history of abuse and environmental degradation. It presents a complex set of problems that requires the collaborative approach involving a community of diverse professional disciplines, public agencies, and concerned citizens. By drawing on multiple influences and past experiences, I created a transdisciplinary and a communitycentered design approach that was relevant to the issues surrounding watershed pollution.

This project used design methods and products to ask visitors to understand how their personal attitudes and actions are connected to the health of their environment. The goal was to create an educational exhibition surrounding the challenges to improve the watershed, stimulate a call to action, and raise peoples' interest in community intervention and action. The cornerstone of the project is "CreekDog", an interactive responsive web site that allows citizens to report and track pollution issues throughout the watershed. CreekDog was created to educate and empower citizens to take an active role in improving their communities by protecting their environment. In addition, the exhibition also included environmental interpretive signage, a portable interactive kiosk, and educational information graphics. Designed in collaboration with local non-profit, Friends of Deckers Creek (FODC), these pieces became tools that continued to educate the public through public outreach efforts after the exhibition.

1 "Understanding Wicked Problems," ac4d: Austin Center for Design, http://www.ac4d.com/home/philosophy/ understanding-wicked-problems, (accessed May 13, 2004). 


\section{ACKNOWLEDGEMENTS}

I take this opportunity to express my profound gratitude and deep regards to present and former members of my committee for their exemplary guidance and constant encouragement throughout the course of this thesis: Eve Faulkes, Chris Barr, Joseph Galbreath, Gerald Habarth, and Kofi Opoku. Special thanks to professors Jack Moffett, Erika Osborne, Shoji Satake, Joseph Lupo, Patrick Jones, Alison Helm, and Mark Brazaitis. I offer my sincere appreciation for the learning opportunities they provided throughout my studies.

I would also like to extend my thanks to these organizations for their contribution to this project; Friends of Deckers Creek, Morgantown Utility Board, and West Virginia Department of Environmental Protection. Their guidance, support, and expertise helped to ensure the success of this project. A special thanks to the Appalachian Stewardship Foundation for providing a grant to help make CreekDog a reality for the citizens of the Deckers Creek Watershed.

I wish to thank the following people for their contributions to this project; Sarah Veselka, Elizabeth Wiles, Suzanne Moore, Timothy Denicola, Martin Christ, Jen Osha-Buysse, Hannah Spencer, Doug Gilbert, Joseph McGrath, Rich Dennis, Brian Carlson, Karl Diefenbach, Patty Diefenbach, Todd Ensign, Ben Gilmer, George Merovich, Vicky Shears, Kenneth Hacker, and Christopher Dale for the valuable information provided by them in their respective fields and their continual collaboration on this project.

I would like to express my deep gratitude to the University Relations - Design team; Angela Caudill, Graham Curry, Susan Crist, Kathy Deweese, Lindsey Estep, Rebecca Herod, Adam Johnson, Laura Spitznogle, and Sheree Wentz, for their valuable and constructive suggestions during the planning and development of this research work.

A sincere thanks to Steven Spriggs for his hard work, innovation, and collaboration on developing CreekDog 2.0.

The completion of this project could not have been accomplished without the unwaivering support of my family: Denny and Dawn Pierce; Shaun, Beth, Grace, and Luke Curtiss; Dan Pierce; Jennifer and Greg McWilliams; John and Karen Conroy; Caitlin Conroy; Patrick and Susan Shirey; and Fran and Ron Shirey.

To my wonderful wife, Kristy and my daughters Violet and Saige; thank you for your love and patience during this journey. Without your care and support this project would not have been possible.

Finally, I wish to thank Chris Schwer and Ashley Yeager. Ashley, thank you for your kind words of encouragement throughout my thesis work. Chris, I dedicate this work to you. May the full life you lived and your insatiable love for the outdoors be an inspiration to us all. 


\section{TABLE OF CONTENTS}

List of Figures $\quad 1$

Introduction $\quad 2$

Chapter One: A Transdisciplinary Approach 3

Chapter Two: Friends of Deckers Creek and the Deckers Creek Watershed 6

$\begin{array}{ll}\text { Chapter Three: Research by Immersive Experience } & 7\end{array}$

Perspectives
My Immersive Process

Chapter Four: Defining a Need 12

$\begin{array}{ll}\text { Defining a Need } & 14 \\ \text { CreekDog Web Application } & 14\end{array}$

Pollution

Construction Stormwater Pollution

Stream Dredge and Fill $\quad 15$

Suspicious Oil and Gas Drilling Activity

Untreated Sewage

Mechanics: How does CreekDog work?

$\begin{array}{ll}\text { CreekDog and Youth Make an Impact } & 17 \\ \text { CreekDog } & 19\end{array}$

CreekDog 2.0 and Partnership with Appalachian Stewardship Foundation 23

Youth Advisory Board

Further Web Development $\quad 24$

Improving Reporting and Expanding Communication

Responsive Redesign

Geolocation Recognition

CAPTCHA: Telling Humans and Computers Apart Automatically

Creating Dialogue: Social Media Integration, Sharing, and Commenting 25

Chapter Five: Building context and educating the audience 29

The Goal of the Exhibition
Waterfall Photographs

Photograph Series $\quad 32$

Poster $\quad 35$

Participatory Marble Survey $\quad 37$

Rail Trail Signage $\quad 40$

CreekDog Display $\quad 42$

Information Graphics and Data Visualization 48

Untreated Sewage in Our Waterways 49

Acid Mine Drainage, the Richard Mine, and FODC Remediation Projects 51

Trash and Litter $\quad 55$

Data Visualization Map $\quad 57$

$\begin{array}{ll}\text { Conclusion } & 61\end{array}$

Bibliography $\quad 62$ 


\section{LIST OF FIGURES}

Figure $\quad$ Page

$1.1 \quad$ Forrest Conroy's Interpretation of Nicolescu's Definitions of Transdisciplinary 5

2.1 Deckers Creek Entering the Monongahela River in Morgantown, WV 6

4.1 CreekDog Logo 14

4.2 CreekDog Web and Mobile Application 15

4.3 CreekDog Service Diagram of Touchpoints and Audience 18

4.4 CreekDog Issue Report 82 19

4.5 Email, Morgantown Utility Board for CreekDog Issue Report 20

4.6 Incident Report from West Virginia Department of Environmental Protection 21

4.7 Photograph Documentation from West Virginia Department of Environmental Protection 22

4.8 CreekDog Home Page 26

4.9 Responsive/Adaptive Design of the New CreekDog Site 26

$\begin{array}{ll}4.10 & \text { CreekDog Create an Account }\end{array}$

4.11 CreekDog Current Issues Page $\quad 27$

4.12 CreekDog Report an Issue Page $\quad 28$

4.13 Individual Report Page 28

5.1 MFA Thesis Exhibition Postcard 29

5.2 Exhibition Title Graphics and Watershed Definition 30

5.3 Photograph of Deckers Creek Waterfall 31

5.4 Photography Series: Fish Sampling and the FODC Clean Creek Program 33

5.5 Photography Series: FODC Outdoor Learning Park 33

5.6 Photography Series: Deckers Dash 10K Race and Water Festival 34

5.7 Photography Series: Kanes Creek Remediation Project 34

5. 8 "A Stream Runs Through It," Poster 36

5.9 Do you know how to report a serious pollution issue? Participatory Marble Survey 37

5.10 Would you take action to report a serious pollution issue? Participatory Marble Survey 38

5.11 NASA Apollo 17 Crew Photograph of Earth, $1972 \quad 39$

5.12 CreekDog Rail Trail Sign $\quad 40$

5.13 CreekDog Display Plan Drawing $\quad 42$

5.14 CreekDog Display Water Festival and Holiday Social 43

5.15 CreekDog Display at the MFA Thesis Exhibition 44

5.16 CreekDog Display, MFA Thesis Exhibition, Detail 45

5.17 CreekDog Display, MFA Thesis Exhibition, Detail - Injection Well Comment 46

5.18 Untreated Sewage in Our Waterways Infographic 49

5. 19 Untreated Sewage in Our Waterways Infographic detail 50

5.20 Acid Mine Drainage Infographic 51

5.21 Acid Mine Drainage Infographic Detail 52

5.22 Trash and Litter Infographic 56

5. 23 Floor Map Data Visualization: Pollution in the Deckers Creek Watershed 58

5. 24 Floor Map Data Visualization at the MFA Thesis Exhibition 60 


\section{INTRODUCTION}

Seven years ago, I left my home in Pittsburgh, Pennsylvania and traveled across the MasonDixon line to begin my new life in Morgantown, West Virginia. I took a job working as an inhouse designer for West Virginia University. I was hired for my experience in creating and implementing brands and for my collaborative approach to design. Prior to West Virginia University, I ran my own brand design company and was employed at an engineering and planning firm, where I worked with a variety of professionals. I was immersed in an environment where I had the opportunity to work with engineers, urban planners, environmental scientists, archaeologists, writers, public involvement specialists, and public officials. Much of the research and planning in these fields requires a collaborative approach where the public and profession engage in a two-way dialogue to facilitate a strategic approach. My role as a designer was to find ways to present to the public all of the complex research and processes that these professions entail. In order to be able to interpret these complex issues for a diverse public audience, I first had to understand them myself. This understanding not only included the objectives of these current projects but also carried forth the strategic goals of the company and the public agencies involved. As my academic and professional careers have evolved, my role as a designer has changed from being an interpreter across disciplines to building strategies that employ diverse and relevant disciplines.
When I arrived in Morgantown I discovered a prominent stream named Deckers Creek. I marveled at the beauty of the stream and envisioned teaching my children, as I was taught, to fish. As an avid angler and outdoor lover, I was dismayed to find out that the stream had suffered years of pollution and neglect. I made a value-based decision to involve myself with Deckers Creek and to make a socially conscious effort to improve my adopted community. Improving the watershed benefits the community by increasing public health, economic health, and recreation. ${ }^{2}$

The origin of CreekDog begins with the question, "How do we prevent pollution in Deckers Creek?" This question is simple, but for Deckers Creek the problem of pollution is vast and complex. Addressing this question required immersive experience. These experiences gave me an opportunity to collaborate with a multitude of experts across various disciplines and gave me a well-rounded knowledge base of challenges facing the Deckers Creek Watershed.

This experience also provided me with an opportunity to expand my process and develop a more robust skill set within the field of design. Beyond design methods, I applied my skills to the watershed as a citizen researcher, volunteer, and most recently, as a board member to local non-profit organization and watershed advocacy group, Friends of Deckers Creek.

\footnotetext{
${ }^{2}$ Alyse Schrecongost and Evan Hansen, "Local Economic Benefits of Restoring Deckers Creek: A Preliminary Analysis," Friends of Deckers Creek, August 2005, Publications, http://www.deckerscreek.org/images/stories/pdf/ DeckersEconomicAnalysis.pdf, (accessed May 15, 2014).
} 


\section{CHAPTER ONE: A Transdisciplinary Approach}

In order to explain transdisciplinary methodology approaches to complex social issues, it is beneficial to explore its definition and meaning. In the Transdisciplinary Evolution of Learning, Basarab Nicolescu, a theoretical physicist, explains the difference between disciplinarity, multidisciplinarity, interdisciplinarity, and transdisciplinarity. ${ }^{3}$

Multidisciplinarity approaches a research topic from several disciplines at the same time. The study of art history is one such example where a combination of the studies of religion, history, geometry, and philosophy could be applied. While multiple disciplines are borrowed from and applied, they ultimately serve a single purpose and discipline exclusively.

Interdisciplinarity differs in its approach and is the transfer of one field of study to another or the combination of two or more fields to create a new discipline. An example of this would be combining math and physics to create the field of mathematical physics.

Transdisciplinarity infers, by its prefix, that it is at once between, across, and beyond disciplines. It transcends disciplinary study to create a new reality and a holistic understanding of our place in the world. Transdisciplinary study is complimentary to disciplinary. While it may use knowledge from multiple disciplines it creates a new holistic understanding of the problems at hand. The result of this unified knowledge is a creative research approach that often results in unexpected and innovative outcomes.
Perhaps the reason the design field continues to evolve is because it exists in collaboration with many other professions and disciplines. From my personal perspective I see the experience of an in-house designer as uniquely positioned for a transdisciplinary approach because they are immersed in collaborative environments. In-house designers work in collaboration with many disciplines. Because they are immersed within the organization they have the opportunity to gain a global mindset of the internal systems of the company and its mission. This can only happen if leadership within the company places value on the participation of these diverse teams. Companies hire such firms as IDEO, Frog Design, and Adaptive Path to help them employ these collaborative models within their own organizations. ${ }^{4}$

To do his work, an in-house designer must collaborate with various professionals across many disciplines. Designers' success is directly related to the success of their company and their co-workers. The essence of design is to create effective and relevant solutions. To do so, a designer must have a deep knowledge of the company and the other professionals around them. They must be able to create strategy to support their company and position it for success.

\footnotetext{
${ }^{3}$ Basarab Nicolescu. "The Transdisciplinary Evolution of Learning." (Talk at the American Educational Research Association (AERA), Annual Meeting, Montréal, Canada, April 1999, Round-Table) Basarab Nicolescu. http://basarabnicolescu.fr/Docs_articles/AERA_April_1999.pdf (accessed April 26, 2014).

4 "Understanding Wicked Problems," ac4d: Austin Center for Design, http://www.ac4d.com/home/philosophy/ understanding-wicked-problems, (accessed May 13, 2004).
} 
Tim Brown, CEO and president of IDEO, describes the ideal collaborative professional as being "T-Shaped." He states, "these are people with deep analytical skills (the vertical stroke of the T) but also broad empathy toward those other skills and disciplines encountered in business (the horizontal stroke of the T). These highly adaptable, rapid learners turned out to be ideal management consultants." ${ }^{5}$

He goes on to talk about the benefit to designers. He says, "nothing beats working with interdisciplinary teams when it comes to strengthening the empathy gene. It reduces the mystery of other crafts and it helps build a common language."

This common language helps to create a mutual understanding between professionals and helps to spread a universal knowledge about the mission of the organization. Based on Nicolescu's definitions, I would modify Browns statement by changing "transdisciplinary" for "interdisciplinary" because I feel that he is speaking about situations that transcend disciplines. The common language created by a transdisciplinary effort also becomes a means to communicate this mission to a wide audience.

Dispelling the mysteries of these disciplines can be very difficult and we do not always have the benefit of working with other professionals that are, as Brown describes, "T-shaped" people. Concepts dealing with science, engineering, economics, and technology are often presented in intradisciplinary terms. ${ }^{6}$ This becomes a problem when these complex concepts need to reach a public audience. For instance, a non-profit, community-based organization relies on public support to achieve its goals. These organizations have missions that deal with finding solutions to complex societal issues that face a culmination of political, economical, and cultural challenges, among others. Their data, research, and the benefits of their overall mission must be understandable to a wide audience of laypersons. This includes the people for whom they administer, their supporters, and to the general public.

Intensive study within a particular discipline is beneficial because knowledge and skills can be acquired quickly and with a deep understanding. Traditionally, most universities and educational institutions operate in this manner. When graduates enter the workforce, the walls of these disciplinary silos begin to break down as we become exposed to more collaborative environments. Many of the soft skills that we attain as we develop professionally are a result of adapting to these collaborative environments. These collaborations result in a greater unified knowledge. Often when it comes time to speak to a wider audience, we end up communicating in the voice of our field of study. We may be extremely well versed at educating the public about the intricacies of our discipline as it relates to a certain social

\footnotetext{
${ }^{5}$ Tim Brown, "On Being T-Shaped," Hack 2 Work, Essential Tips for the Design Professional, September 2009 , (accessed April 26, 2014), http://www.core77.com/ hack2work/2009/09/on_being_tshaped.asp.

6 Tim Brown, interview by Morten T. Hansen, January 21, 2010, "IDEO CEO Tim Brown: T-Shaped Stars: The Backbone of IDEO's Collaborative Culture," Chief Executive. net, (accessed April 26, 2014), http://chiefexecutive.net/ ideo-ceo-tim-brown-t-shaped-stars-the-backbone-ofideoae\%E2\%84\%A2s-collaborative-culture.
} 


\section{A Visual Understanding of Nicolesu's Definition of Transdisciplinary}

cause. However, relying on a single discipline, or even several disciplines, becomes problematic because the information being presented is fragmented. This fragmented approach can provide the details of a complex system as it pertains to particular disciplines but it fails to create a comprehensive narrative. ${ }^{7}$

This fragmentation creates gaps in knowledge for the people we intend to serve and can create conflict and differences between collaborators. Liz Sanders says that this gap is created by the, "differences in: skill sets between disciplines or areas of expertise, specialized languages, boundaries, edges and domains of the unique disciplines, and mindsets and egos of the people involved."

The main differences between these have to do with "education and mindset." To remedy this gap, Sanders calls for a shift in mindset where the "real experts," the people we are designing for, are included on the front end of the design process. This changes the method of the strategic team from designing for to designing with. She says that this is the key to breaking down disciplinary and/or cultural boundaries.

The role of the designer can be invaluable when working towards social change. As designers, we are communicators, narrative builders, and facilitators capable of bridging connections across disciplines in ways that resonate with the audience.

To create change, it becomes imperative that the designer be highly adaptable to gain a deep understanding of these topics so they can help create a "common language" for their audience. This language combines disciplinary knowledge and speaks to the

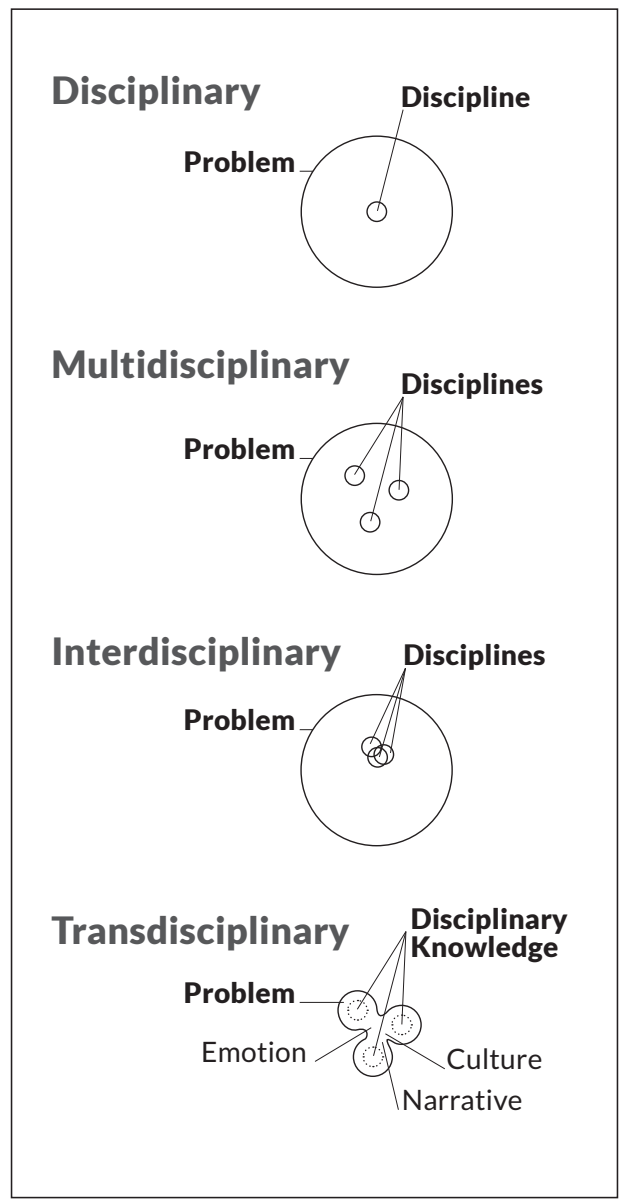

Figure 1.1: This figure uses Nicolescu's definitions to visually explain the differences between multidisciplinary, interdisciplinary, and transdisciplinary approachs. Here the definition of the problem and the resulting approach is tailored to a deeper understanding of the audience.

emotions and motivations of the audience. It creates a language that comes from a holistic perspective, one that culminates both the knowledge of multiple disciplines and a deep understanding of the audience (empathy) and results in a new reality.(fig.1.1)

7 "CIRET, CENTRE INTERNATIONAL DE RECHERCHES ET ÉTUDES TRANSDISCIPLINAIRES," Le Projet Moral 1987, Last modified on : Saturday, October 202012 12:11:49, http://ciret-transdisciplinarity.org/moral_project.php, (accessed April 26, 2014).

8 Elizabeth Sanders, "Stepping Stones Across The Gap, Explorations in the Generative Design Space," essay, Reprinted from Halse, J., Brandt, E., Clark, B. and Binder, T. (Eds.) Rehearsing the Future, The Danish Design School Press, 2010, http://www.maketools.com/articles-press/rtf. pdf, (accessed April 26, 2014). 


\section{CHAPTER TWO: Friends of Deckers Creek and the Deckers Creek Watershed}

In order to discuss Deckers Creek and the organization that is involved in improving and protecting its watershed we should provide further explanation of Friends of Deckers Creek (FODC) and the history of the watershed. The following information is provided on their website:

Friends of Deckers Creek was established in 1995, began receiving funds for projects in 1997 and received 501(c) 3 status in 2000. FODC established its Education Program in 2006 and Youth Advisory Board in 2007. Since then FODC has reached over 750 regional youth through a variety of programs, providing them the tools needed to be the next generation of environmental stewards. ${ }^{9}$

Deckers Creek is a scenic tributary to the Monongahela River (fig.2.1) in north central West Virginia. From its headwaters outside the historic town of Arthurdale, Deckers Creek meanders through Preston County into Monongalia County where it descends through a steep scenic gorge. This beautiful section of Deckers Creek is filled with waterfalls, boulders, and rockslides, contains world class kayaking, and is frequented by kayakers, rock climbers, bikers, and swimmers. From here, Deckers Creek passes through several communities and into Morgantown, where it empties into the Monongahela River. Over the years, numerous pollutants have degraded Deckers Creek. These pollutants include, but are not limited to, acid mine drainage (AMD), bacteria from combined sewage overflows, heavy metals, sediment, trash, and abandonment, which negatively impact the 64-square mile watershed. The biggest threat to the watershed is AMD. AMD

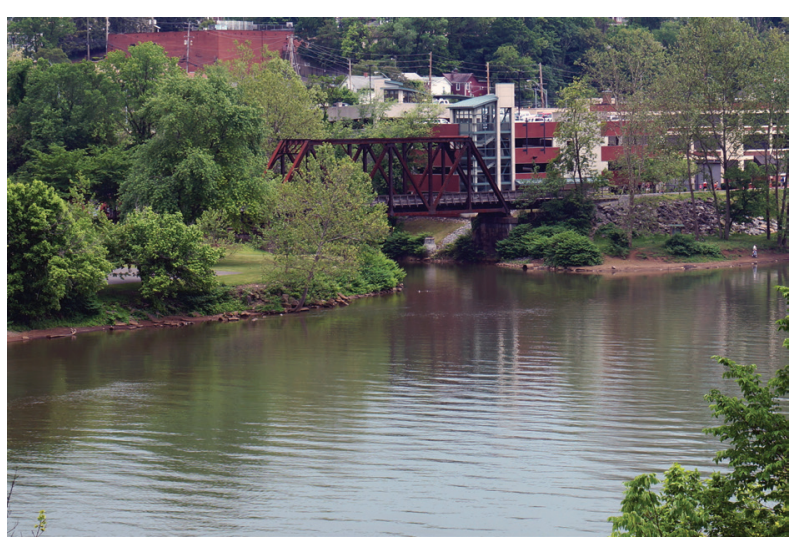

Figure 2.1: Deckers Creek enters the Monongahela River in Morgantown, West Virginia.

impacts stream ecosystems through acidity, ferric iron $\left(\mathrm{FE}^{3+}\right)$ precipitation, oxygen depletion, and releases of heavy metals associated with coal and metal mining, such as aluminum $\left(\mathrm{Ai}^{i^{3+}}\right)$ zinc $\left(\mathrm{Zn}^{3+}\right)$, and manganese $\left(\mathrm{Mn}^{1+}\right)$. This product, of abandoned coal mines, destroys the environmental quality of Deckers Creek and its tributaries, turns the waters red-orange, and creates acid conditions in which fish and macroinvertebrates cannot live.

Friends of Deckers Creek is working to clean-up the decades of environmental degradation that have been inflicted on the watershed. Through remediation projects, trash clean-ups, community outreach, and environmental education, it was FODC's goal for the entire length of Deckers Creek to be fishable by 2010 and swimmable by 2015 ; turning the creek from a liability into a community asset. However, delays in getting a treatment facility at the devastating Richard mine discharge have pushed back this deadline to $2020 .{ }^{10}$

\footnotetext{
9 "History," Friends of Deckers Creek, History. http://www. deckerscreek.org/about/history (accessed April 27, 2014)

10 "About Friends of Deckers Creek," Friends of Deckers Creek, http://www.deckerscreek.org/about/history (accessed April 27, 2014).
} 


\section{CHAPTER THREE: Research by Immersive Experience}

"Transdisciplinarity is globally open.

Transdisciplinarity entails both a new vision and a lived experience. It is a way of selftransformation oriented towards knowledge of the self, the unity of knowledge, and the creation of a new art of living in the society." Basarab Nicolescu ${ }^{11}$

\section{Perspectives:}

Transdisciplinarity creates a new reality where the cultural rift between art and science no longer exists. Design is uniquely positioned for this approach because its methodologies are a combination of these cultures. As I tackled the issues of watershed pollution, I often found inspiration and relevance in the poetry and philosophy of Gary Snyder. In the preface to his book, No Nature, he begins to define nature. We see humans and human activity as being separate from nature. Snyder says, "Human societies each have their own nutty fads, mass delusions, and enabling mythologies. Daily life still gets done. Wild nature is probably equally goofy, with a stunning variety of creatures somehow getting by in all these landscapes. Nature also means the physical universe, including the urban, industrial, and toxic. But we do not easily know nature, or even know ourselves. Whatever it actually is, it will not fulfill our conceptions and theoretical models. There is no single or set "nature" either as "the natural world" or "the nature of things." The greatest respect we can pay to nature is not to trap it, but to acknowledge that it eludes us and that our own nature is also fluid, open, and conditional. Hakuin Zenji describes it as "selfnature that is no nature/ ... far beyond mere doctrine." An open space to move in, with the whole body, the whole mind." ${ }^{12}$

I find it interesting that he includes "urban, industrial, and toxic" to his definition. We often see these things as separate from nature and separate from ourselves. In this definition he also talks about 'self-nature' and its connection to a greater holistic meaning of the word nature. Many of the problems afflicting the Deckers Creek Watershed are varied and complex and face the same challenges of other urban watersheds across our nation.

Deckers, like many of our urban waters, are both highly visible and ignored or neglected because collectively:

\section{Citizens fail to see their connection to these waters;}

2. Citizens do not feel empowered to take action and create change;

\section{Citizens do not understand the complexity and the severity of the problems at hand.}

\footnotetext{
${ }^{11}$ Basarab Nicolescu, "The Transdisciplinary Evolution of Learning." (Talk at the American Educational Research Association (AERA), Annual Meeting, Montréal, Canada, April 1999, Round-Table) Basarab Nicolescu. http://basarabnicolescu.fr/Docs_articles/AERA_April_1999.pdf (accessed April 26, 2014).

12 Gary Snyder, "Preface," in No Nature: New and Selected Poems. (New York and San Francisco, Pantheon Books, 1992).
} 
Individual disciplines can work to tackle

pollution issues, but it takes new and innovative

thinking to create an approach that will educate, empower, and create the awareness needed to mobilize collective action towards attitude change and action.

Through a national effort to bolster innovation and economy, a large push has been made towards advancing the STEM (science, technology, engineering, and math) sciences. Many who see the connection between science and art have argued for STEAM, the inclusion of art to be included in these efforts. ${ }^{13}$ This has created much debate throughout educational institutions, especially those of higher education. By allowing art, culture, visual communication, storytelling, emotion, to be part of the equation, we are able to bring the audience in as partners in creating solutions rather than authoring solutions for them.

As Nicolescu points out, "instilling complex and transdisciplinary thought into the structures and programs of the university will permit its evolution towards its somewhat forgotten mission today - the study of the universal." He calls for an educational experience that creates the "reunification between scientific culture and artistic culture."14

Friends of Deckers Creek relies on the expertise of a wide range of professionals. A few of the disciplines they enlist are geologists, acid mine drainage specialists, wildlife and fishery scientists, wetland specialists, financial and accounting experts, educators, parks and recreation personale, community organizers, lawyers, and public artists.
At this date, the term 'immersive experience' has become a buzzword synonymous with web designs, video games, and virtual reality. My intent on using this term is not of a virtual reality, but of an actual one.

The field of design has evolved from a product, result-based profession where the designer was the author and creator to one that is more focused on the human experience. ${ }^{15}$ This is often referred to as a human-centered design process - one where experiential research comes into play. Human-centered design focuses primarily on establishing empathy. IDEO is an innovation and design firm that uses a human-centered, design-based approach to help organizations in business, government, healthcare, education, etc,. Tom and David Kelly, founders of IDEO, explain empathy as this:

For us, it's the ability to see an experience through another person's eyes, to recognize why people do what they do. It's when you go into the field and watch people interact with products and services in real time - what we sometimes refer to as "design research." Gaining empathy can take some time and resourcefulness. But there is nothing like observing the person you're creating something for to spark new insights. ${ }^{16}$

13 Malia Spencer, "Full STEAM ahead: As STEM discussions heat up, there is a growing desire to add an 'A' for art," Pittsburgh Business Times, Updated: August 16, 2012, (accessed April 27, 2014), http://www.bizjournals.com/ pittsburgh/print-edition/2012/08/17/full-steam-ahead-asstem-discussions.html?page=all.

${ }^{14}$ Basarab Nicolescu, "The Transdisciplinary Evolution of Learning." April 1999

15 Jon Kolko, Wicked Problems: Problems Worth Solving, ac4d: Austin Center for Design, Jon Kolko, 2012.

16 Tom and David Kelley, "Why Designers Need Empathy," The Eye: Slate's Design Blog, Slate, November 8, 2013, 11:02 a.m., http://www.slate.com/blogs/the_eye/2013/11/08/ empathize_with_your_end_user_creative_confidence_by_ tom_and_david_kelley.html, (accessed April 27, 2014).. 
The most effective and powerful way we can empathize with our audience is by creating immersive experiences. Immersion is an anthropological approach that takes the designer into the field where they engage with individuals to get a sense of their habits, behaviors, motivations, perspectives, cultures, emotions, and experiences. It helps to dispel stereotypes and assumptions about the audience and stakeholders. It also helps to curtail presumptive solutions. The immersive experience creates a deeper knowledge of environment and its influences on individuals and their attitudes. It can highlight challenges and obstacles that would otherwise be overlooked and remain undiscovered.

This method is a very effective for gaining a transdisciplinary perspective while presenting several challenges for the designer. The biggest challenge is establishing trust with the communities with whom you are trying to empathize. Doing so, takes a significant amount of time. Depending on what the project will allow, this could take weeks, months, or even years. Time spent can build affinity with the people you intend to serve.

The way that I created these immersive experiences for myself was by attending events and public meetings, or volunteering for events hosted by Friends of Deckers Creek. Eventually this active involvement led to becoming a member of their board of directors. By creating an active role for myself in service to the organization, I was able to gain a better insight into the inner workings of the organization. This created a more in-depth knowledge of the history of the watershed and the organization, structure of the organization, group dynamics, public outreach and education efforts, scientific research, remediation projects, grant writing, budgetary concerns, and youth involvement. As a newcomer to the area, It also helped me gain a more comprehensive understanding of the physical space - the landscape of the watershed and the complex pollution issues that affect it.

While this collaborative involvement helped me to gain a broad understanding of the organization, it also helped them by providing 'outsider' perceptions. Friends of Deckers Creek lead many efforts and has a variety of projects and events that involve the communities throughout the watershed.

The other way we can build trust and gain new insights is to involve the users in the process at a very early stage. Involving the public throughout the process also helps to strengthen the brand image of the product or service you are designing. In this way the public becomes part of the brand. It becomes a way of establishing brand affinity or expert users before the final product launches.

\section{My Immersive Process:}

Looking back on my experience and the projects that were created, I realized that I had created a process for myself that provided me a unique opportunity and perspective on the problems at hand. 
Throughout these experiences, I often saw myself as both an "outsider" and an "insider" to the Deckers Creek organization and the disciplines involved. As designers, we are frequently met with this duality of existence. While this situation may have its challenges, it helps us to bridge the divide where there are gaps in knowledge. In a company model, it helps us to create better connections between our clients and their audience. In a community-based situation, like this one, it helps us to understand the connections between organizations, disciplines, agencies, and citizens.

\section{My process loosely followed this sequence; immerse, explore, empathize, assess, create,}

reassess. It is important to note that, while I refer to this as "my process," that these steps happened collaboratively. The experiences I created for myself gave me greater insight into disciplinary knowledge and it allowed me to empathize as both an "insider" and an "outsider." Having this dual perspective allowed me to identify gaps in knowledge. These gaps included facts and expertise, but it also gave me the opportunity to identify opportunities for narrative. These narratives are important for gathering community support because they bring emotion and culture into the process. Only when we identify these gaps in knowledge, can we begin to build solutions to help bridge these voids.

Many of my experiences took the form of volunteer work. Volunteer opportunities like these benefit the organization as well as the designer. Organizations rely on the work of volunteers to carry out their mission - for designers this becomes a way to gain first-hand insights into how the association's mission is tied to its process and its stakeholders. For a designer, this "outsider" knowledge can help identify obstacles and challenges to their mission.

For instance, while helping with FODC's Clean Creek Program, I was able to explore portions of the stream that I had not visited before. By participating in the fish sampling, I was able to see first-hand how pollution effected aquatic life in the stream. I was able to combine the knowledge I acquired through my own research about acid mine drainage, sedimentation, and high fecal coliform levels that affect portions of the upper portion of the watershed, and make qualitative comparisons between pollution impacts and fish diversity. Going back to our challenge of educating and empowering citizens to make a change in their watershed, I went back to our original question, "how do we prevent pollution in Deckers Creek?" This led me to other, more specific questions, "would the average citizen be able to identify illegal construction practices, stream fills, or be able to identify a straight pipe that is depositing untreated sewage into a stream?" This gave me the opportunity to pose these questions to experts and it gave me the insight to better develop tools, such as CreekDog, and educational materials, like information graphics for the exhibition. I was able to 
assess challenges and questions that experts, citizens, and public agencies face with regard to resolving pollution issues in the watershed. It gave me an opportunity to see these pollution problems from a variety of viewpoints. As I was uncovering the complex nature of these issues, I was able to find ways of untangling these narratives for a greater audience. One example of this is fecal coliform bacteria from untreated sewage in our waterways. This problem has a variety of sources that are not always easily identified. One result of exploring this issue can be seen in the Untreated Sewage in Our Waterways Infographic (fig.5.17). The result took the form of an information graphic that relied on expert disciplinary knowledge and emotional narrative. It gave me a chance to talk about a subject that is not an inviting one - fecal matter. This graphic helped make the topic more inviting for the audience and allowed me to show their personal connection and responsibility to this form of pollution. 


\section{CHAPTER FOUR: Defining a Need}

\section{Defining a need:}

As a member of Friends of Deckers Creek, I receive a seasonal newsletter that provides updates on the state of the stream. On their website and within their newsletter they provide a call-to-action, asking you to become a "Watershed Watchdog". They provide a "list of watershed pollutants such as illegal dumps, untreated sewage, suspicious drilling activity, stream or wetland dredge and fill, etc. and who to contact in Monongalia and Preston Counties, West Virginia". ${ }^{17}$

To be able to take effective action, a "watchdog" would have to know what they were looking for and who to contact. To do so they would likely go to the site, find the Watershed Watchdog page, locate the list of pollutants and figure out where to report the information.

This requires a lot of effort, knowledge, and time for the person making the report. For me, this

\section{raised several questions:}

1. Would the person making the report be able to provide enough information to the responsible agency so that they could take effective and immediate action?

2. If they did, would the report reach them in a timely manner?

3. Would the agency be able to find the correct location?

4. Would the person know enough to have the ability to identify a pollution problem to report the incident?

\section{Would they feel empowered to make a report} and what type of obstacles would prevent them from taking action?

We looked to create faster and easier ways for someone to make the correct contact in a timely manner.
To find a solution, I looked towards existing technology. The ease and immediacy of a mobile or smartphone application seemed like good answer to this problem. Smart phones are becoming more popular, accessible, and affordable. I think there is a great future for mobile applications that allow responsible, environmentally minded citizens to take action. So what eco apps already exist? The U.S. Environmental Protection Agency (EPA) lists 2,110 watersheds for the continental United States and another 150 in Alaska and Hawaii. ${ }^{18}$ Surely someone out there has created something aimed at protecting our precious watersheds? Unfortunately, at the time, I found that there were very few existing eco applications. It appears most of the ones that exist focus on minimizing our carbon footprint, recycling, eating local, or buying products responsibility. It was not likely that I would find many that dealt with water resources, watersheds, or stream health. One that I did find was the Creek Watch iPhone application developed by IBM. ${ }^{19}$ Creek Watch allows the average citizen to report on the health of their streams in four steps. Citizens monitoring a stream can snap a photo; select the water level, the water flow, and the amount of trash nearby. This information is uploaded to a public repository, where local watershed groups,

\footnotetext{
17 "Be a Watershed Watchdog," www.deckerscreek.org, (accessed April 11, 2011).

18 "What is a Watershed?" United States Environmental Protection Agency, http://water.epa.gov/type/watersheds/ whatis.cfm, updated March 6, 2012, (accessed April 26, 2014).

19 "Creek Watch: Explore Your Watershed," IBM Creek Watch Application, http://creekwatch.researchlabs.ibm.com, (accessed April 27, 2014).
} 
agencies, and scientists can use it to identify and locate problem areas, and develop an action plan.

I expanded my research into web applications and environmental groups that provide citizens with the means to take action. Two websites that I found particularly useful were Sierra Club and SeeClickFix.

SeeClickFix allows you raise awareness about issues in your neighborhood. Using SeeClickFix you can view, report, and track issues in your area. This alerts government, media, and community groups to non-emergency issues and encourages them to take action. SeeClickFix makes use of Google Maps, allowing users to pinpoint exact location on the map. You can even upload a photo. ${ }^{20}$

On Sierra Club's website they have a "Take Action" page. ${ }^{21}$ This page allows you to view actions, join campaigns, and sign petitions. When you choose an action, Sierra Club provides a simple form where you can fill out your personal information and it also provides a form email directed specifically to its intended audience. They provide you with a well-written letter that you can personalize. When you send your letter it goes directly to the proper government official.

Since this initial research, more watershed applications have arrived such as the EPA's My WATERS Mapper. ${ }^{22}$

However, this application, as many of them do, only presents data that they have collected in a map-based format. It does nothing to allow citizens the ability to report pollution issues.
What is the success of these applications? In the Case of IBM Creek Watch and SeeClickFix, by enabling citizens to capture and share photographic evidence agencies are provided with the ability to identify pollution and create a plan before they arrive at the scene. By creating a reporting system that is mobile and mapbased, citizens can mark the location on-site. It provides agencies with an accurate location. What is valuable about these applications is their method of empowering citizens to take action. They create a connection between citizen and public agency. The limit to these applications is in how communication exists between the two. It takes on a one-directional form either with citizen providing information to agency, or agency providing information to citizen. It lacks dialogue and a method for each, both citizen and agency, to arrive at solutions together. Dialogue begins to establish trust between the two. In my experience, the vast separation between agencies and citizens builds distrust from both sides. An effective solution should bring the two together. This analysis led us to build CreekDog (fig.4.1), a web application that empowers the citizen, and provides detailed reports to public agencies.

\footnotetext{
20 "How it Works," SeeClickFix, http://en.seeclickfix.com/ how-it-works, (accessed April 27, 2014).

21 "Take Action," Sierra Club, http://action.sierraclub. org/site/PageServer?pagename=TakeAction\&s_ src $=610 Z$ SCAC01, (accessed April 27, 2014).

22 "Waters: My WATERS Mapper," United States Environmental Protection Agency, http://watersgeo.epa. gov/mwm/. (accessed April 27, 2014).
} 


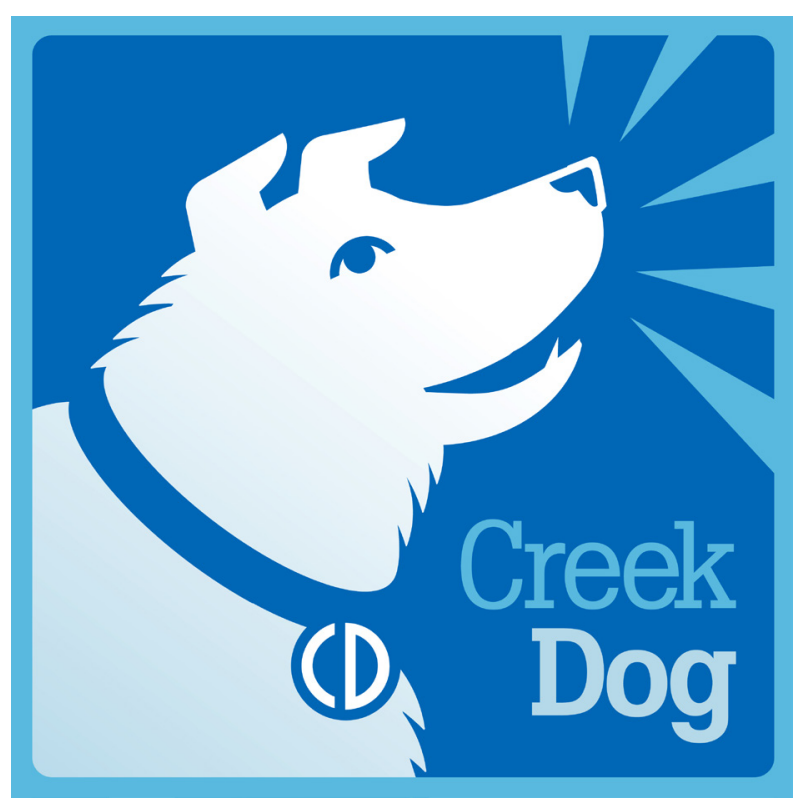

Figure 4.1: CreekDog Logo

\section{CreekDog Web Application:}

Our mission in creating this project is to engage and empower citizens to take action, and to report on potential pollution violations throughout the Deckers Creek Watershed. CreekDog's goal is to create an effective, replicable mobile web tool that allows citizens to make reports to public agencies, and assist the agencies to take efficient action to resolve pollution violations. CreekDog facilitates effective communication between public agency and citizen by increasing the ease of reporting a violation to the correct agency as well as allowing citizens to make the report on scene through their mobile device.

CreekDog.org is a web-based system that allows citizens to report and track pollution issues throughout the Deckers Creek Watershed, a tributary of the Monongahela River. This web site was developed in partnership with a community non-profit watershed association,
Friends of Deckers Creek (FODC), and was based on their Watershed Watchdog Program. FODC's Watershed Watchdog Program calls citizens to take action. CreekDog takes this one step further by providing a tool that facilitates action.

\section{Pollution:}

There are several pollution issues that are known or potential threats to the Deckers Creek Watershed. These threats include construction stormwater, stream or wetland dredge and fill, suspicious or illegal activity related to oil and gas drilling, chemical leaks or spills, illegal trash dump sites, and untreated sewage. The following pollution type descriptions are used on the pollution guide on the CreekDog website. They were created in collaboration with former FODC executive director, Sarah Veselka. ${ }^{23}$

\section{Construction Stormwater Pollution}

The EPA's stormwater program requires construction sites engaged in clearing, grading, and excavating that disturbs one acre or more to obtain a permit. All of these sites must prepare a Stormwater Pollution Prevention Plan (SPPP) which includes measures to minimize the disturbed areas, protect natural features, and control stormwater flowing onto and through the watershed, stabilize soils, protect slopes, establish sediment barriers, and retain sediment on-site. Indicators of this type of pollution include sediment being washed onto roads or into streams, failing erosion control measures such as silt fences, and/or construction sites larger than one acre with no erosion control measures such as silt fences.

\footnotetext{
${ }^{23}$ Sarah Veselka, FODC Executive Director, e-mail correspondences to author, February, 2012.
} 

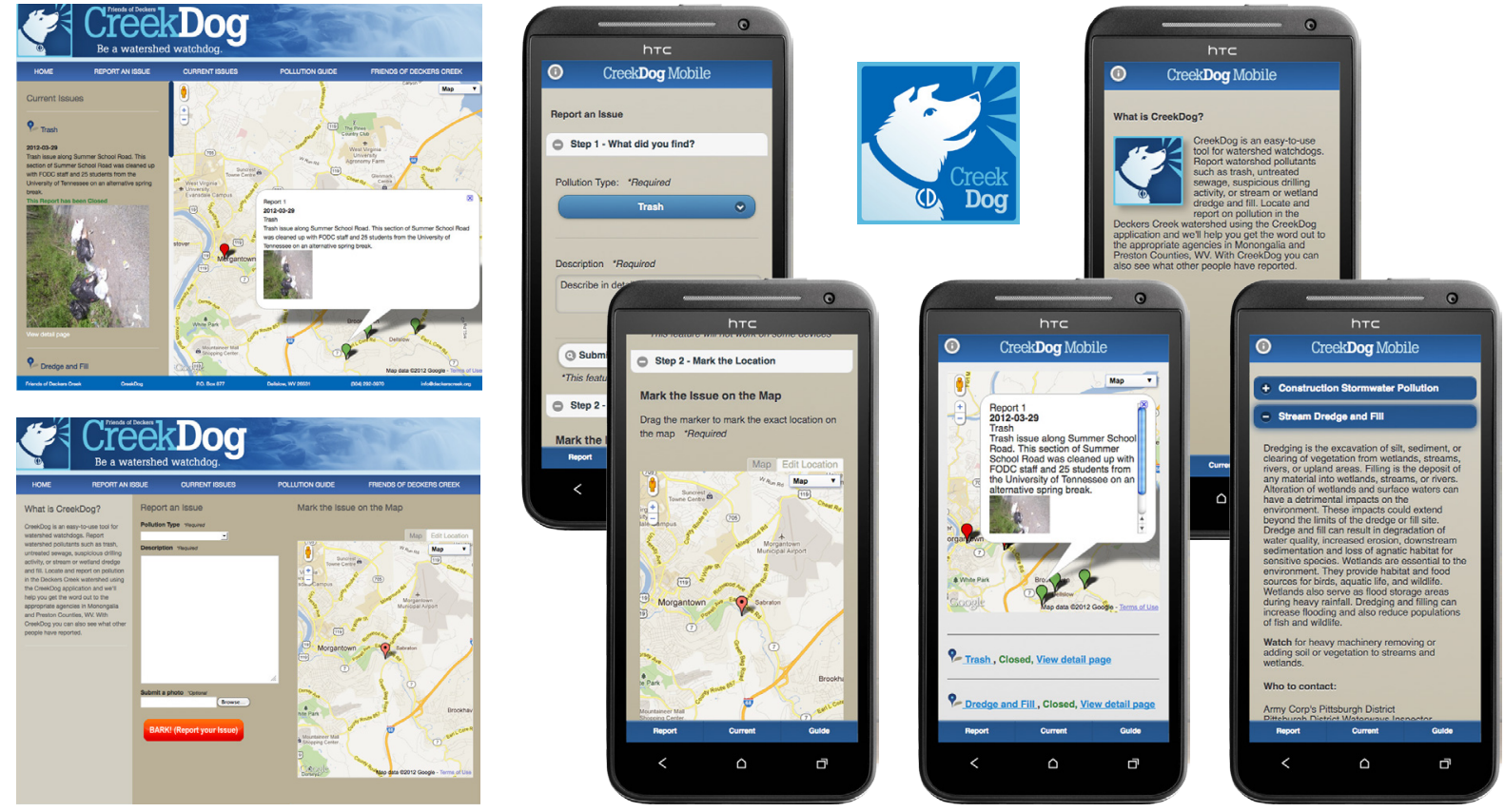

Figure 4.2: First iteration of the CreekDog web application showing designs for both the desktop and mobile versions

\section{Stream Dredge and Fill}

Dredging is the excavation of silt, sediment, or clearing of vegetation from wetlands, streams, rivers, or upland areas. Filling is the deposit of any material into wetlands, streams, or rivers.

Alteration of wetlands and surface waters can have a detrimental impact on the environment. These impacts could extend beyond the limits of the dredge or fill site. Dredge and fill can result in degradation of water quality, increased erosion, downstream sedimentation and loss of agnatic habitat for sensitive species. Wetlands are essential to the environment. They provide habitat and food sources for birds, aquatic life, and wildlife. Wetlands also serve as flood storage areas during heavy rainfall and act as a groundwater recharge. Dredging and filling can increase flooding and also reduce populations of fish and wildlife.

\section{Suspicious Oil and Gas Drilling Activity}

Well pads for Marcellus shale drilling operations require roughly four to five acres of level land. During this clearing and grading process, drilling companies are required to have storm water permits and must prevent sediment from being washed off the ground into streams. They are also required by law to protect streams and wetlands from dredge and fill. If gas companies plan to impact a stream or wetland for access roads, pipelines and/or drill pads, they must obtain a federal permit and mitigate for those environmental losses. Each drill site requires millions of gallons of water to extract the natural gas through hydraulic fracking. Effective August 29, 2011, West Virginia Code of State Rules 35-8 mandates that all horizontal well permit 
applications submitted to the WV Department of Environmental Protection (DEP) include a Water Management Plan (WMP) if more than 210,000 gallons of water will be used in conjunction with drilling, fracturing, or stimulating a well. ${ }^{24}$ If withdrawn from local streams, this could pose a problem for aquatic life, drinking water sources, and livestock water supplies downstream. Modern advancement and technology results in 70-80 percent of the water be reused and recycled. Further, 10-40 percent of the total water used returns to the surface with the extracted gas. ${ }^{25}$ This is called "flowback". Flowback contains salts and fracking chemicals and must be hauled off-site for treatment and/or disposal or diluted, treated, and used again. Because drilling companies do not have permits to discharge pollutants to waterways, they are not allowed to discharge ANY water into streams. Therefore, the only way that flowback can enter streams is through spills or illegal discharges. Any spill greater than a five (5) gallon bucket must be reported. Indicators of this type of pollution include sediment being washed onto roads and into streams from well pad construction, water being discharged into streams, water withdrawals that cause streams to flow extremely low, and truck spills. Current design standards include rock construction entrances to pad roads and sediment traps to inhibit sediment from leaving drill sites and access roads.

\section{Illegal Trash and Litter}

Litter is not only unsightly, but it can also

have negative impacts on aquatic life. Large appliances, cleaning products, and electronics can leach chemicals that are harmful to fish and aquatic macroinvertebrates. Small littered items can also have a significant impact. Cigarette butts, snack wrappers and take-out food and beverage containers are the most commonly littered items. Did you know that cigarette butts are not biodegradable, are concentrated with chemicals and toxins such as benzene, formaldehyde, ammonia, acetone, nicotine, arsenic, and tar, and are the most littered item in America? Studies have shown that a single cigarette butt in about two gallons of water is lethal to water fleas, a tiny crustacean found in fresh and salt water. ${ }^{26}$

\section{Untreated Sewage}

Untreated human sewage can pose serious health risks in our local waterways. It can enter streams from straight pipes, an illegal practice still common in West Virginia. Home septic tanks can also become overloaded during the rainy season or simply grow old and fail and allow untreated waste to flow into drainage ditches and nearby waters. During heavy rains, sanitary sewers can become overloaded and over flow, bypassing treatment. Agricultural practices such as allowing animal waste to wash

24 "Water Management Plans," West Virginia Department of Environmental Protection, Office of Oil and Gas, State of West Virginia 2014, accessed May 15, 2014, http://www.dep. wv.gov/oil-and-gas/Water\%20Management/Pages/default. aspx, (Posted December 7, 2011)

${ }^{25}$ West Virginia Water Research Institute, Final Report: Water Quality Literature Review and Field Monitoring of Active Shale Gas Wells, Phase I, Assessing Environmental Impacts of Horizontal Gas Well Drilling Operations, Prepared for West Virginia Department of Environmental Protection, Division of Air Quality, (West Virginia University, February 15,

2013), accessed May 15, 2014, http://www.dep.wv.gov/oiland-gas/Horizontal-Permits/legislativestudies/Documents/ Water\%20Report\%20Phase\%201\%20submitted\%20 Feb\%2020,\%202013.pdf

${ }^{26}$ Kathleen M. Register, "Cigarette Butts as Litter - Toxic as Well as Ugly," Clean Virginia Waterways, Longwood University, Farmville, Virginia, accessed May 15, 2014, Originally Published in Underwater Naturalist, Bulletin of the American Littoral Society, Volume 25, Number 2, August 2000, http:// www.longwood.edu/cleanva/ciglitterarticle.htm 
into nearby streams during the rainy season, spreading manure and fertilizer on fields during rainy periods, and allowing livestock watering in streams can also contribute to fecal coliform contamination. All three of these untreated sewage transportation methods are known to effect water quality within the Deckers Creek watershed.

\section{Mechanics: How does CreekDog work?}

With Creekdog.org, users can submit a report by choosing a pollution type, providing a detailed description, and uploading a photograph of the issue. Users choose the type of watershed pollutant such as trash, untreated sewage, suspicious drilling activity, or stream/wetland dredge and fill. The photographs help FODC and agencies to properly assess the extent of the issue. By placing a marker on the map or entering the nearest address, the report is posted to the map and Friends of Deckers is notified. Citizens can monitor cleanup progress via the Current Issues page where problem areas are marked red for open issues and green for resolved.

Each submitted report generates a page that can be emailed to the appropriate agencies. This report includes a link for directions to the exact GPS location.

CreekDog also provides a guide to educate and inform citizens so they can accurately identify the types of pollution issues found in the watershed and the corresponding agencies responsible for addressing those violations. The mobile application includes phone links so that those agencies can be contacted and follow ups made immediately.

\section{Audience and Scope}

The project area covers a gradient of community types from rural farms and forests to urban industrial and residential areas. The scope of this proposal includes the Deckers Creek watershed and greater Morgantown-area community. This area is primarily comprised of the Morgan District of Monongalia County, Valley District of Preston County, and the city of Morgantown. There are approximately 40,000 people living in the Deckers Creek watershed and an additional 30,000 West Virginia University (WVU) students and Morgantown residents in the project area. FODC also specifically supports area youth through the Youth Advisory Board. The FODC Youth Advisory Board (YAB) is a group of dedicated youth, ages 18 and younger, interested in clean water and helping the community. Their mission is to increase youth participation in helping clean up the Deckers Creek watershed for conservation, preservation, and recreation through youthled projects and research. YAB members do hands-on activities benefiting local streams, watersheds, and community members. Examples of these activities include stream monitoring for water quality and invertebrate and fish communities, litter clean-ups, raising funds to buy and install recycling containers at local schools, environmental education and outreach for younger children, making rain barrels, and hosting annual fundraising and outreach events. YAB members are involved in these projects from the initial idea, through the grant-writing process, to the end product. CreekDog improves the quality of life for those citizens living in the Deckers Creek Watershed in Monongalia and Preston Counties by improving the health of the natural environment around them, as well 
as improving their ability to stand up and make a difference. CreekDog is has been developed as a model that can easily be expanded to watersheds all across the country.

The target audience combines the following demographic groups in an effort to maximize the positive impact on the watershed:

\section{Advocates, such as watershed association} members, eco-org members, youth members, student orgs, and citizen scientists;

2. Recreationists, such as trail users, kayakers, rock climbers, anglers, geocachers;

3. Stakeholders, such as homeowners, business owners, property owners, public officials, and agencies.
This very generalized list grew out of much more detailed analysis of the audience and the touchpoints (fig.4.3). We created a service diagram to talk about how someone might enter the CreekDog project. It takes the idea of "interaction" from physical and digital spaces. It identifies possible audience members and corresponding deliverable items for all of these possible areas.

Figure 4.3: CreekDog service diagram used to create campaign strategy by defining touchpoints and potential target audience

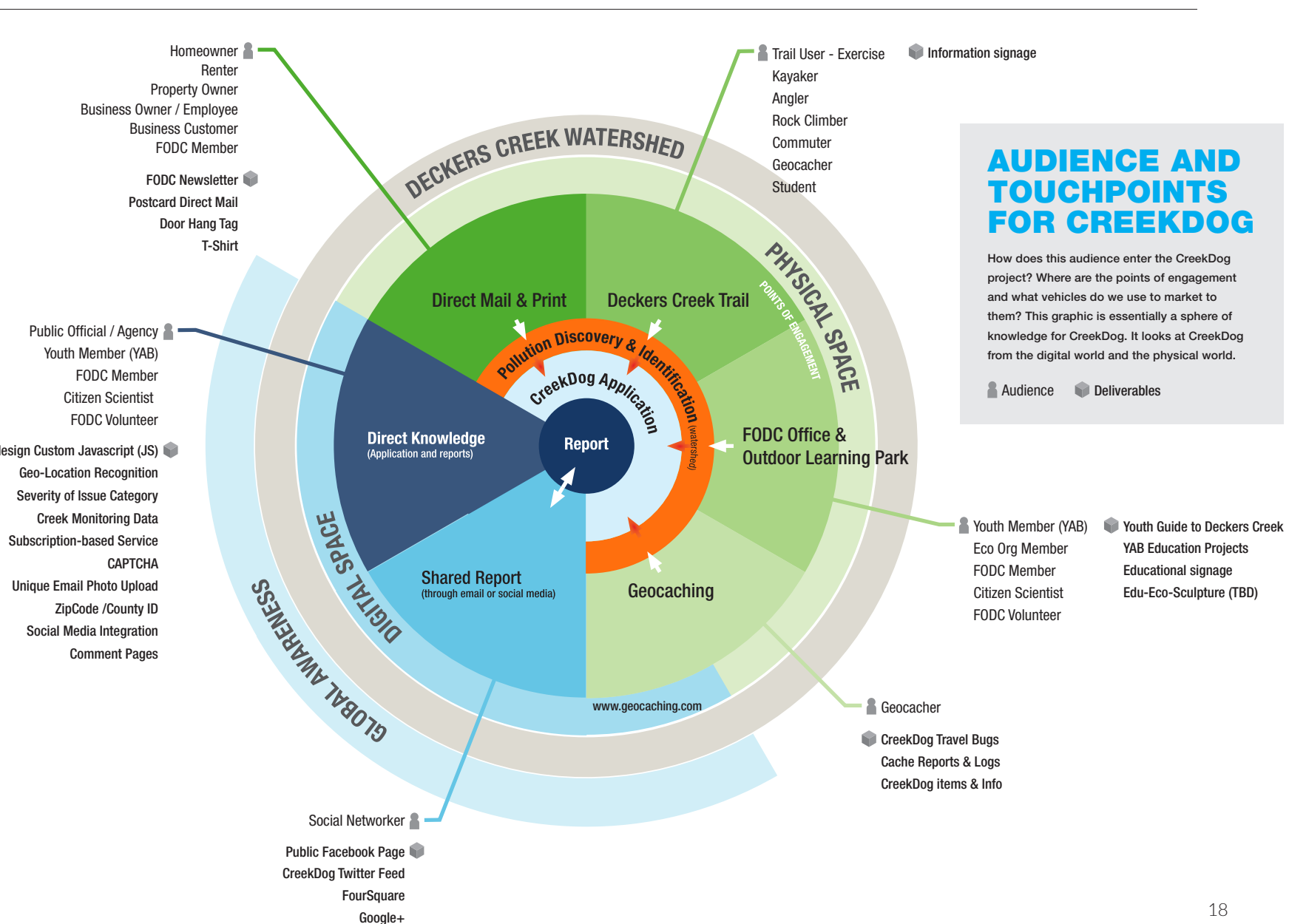




\section{CreekDog and Youth Make an Impact}

On April 20, 2013, a Friends of Deckers

Creek Youth Advisory Board Member issued a

Construction Stormwater pollution issue near

her high school (fig.4.4). Issue Report 82 was

the first report to be sent to a public agency.

The report was sent to the West Virginia

Department of Environmental Protection

(WVDEP) and the Morgantown Utility Board

(MUB). The report was made late on a Sunday

and by the next morning both agencies had

responded to the report and resolved the

issue. In addition to the issue being resolved in an effective manner, this report created the opportunity for these agencies to experience the benefits of CreekDog firsthand.

A sixteen-year-old was able to make an impact to help her community and CreekDog helped to bridge a connection with the appropriate agency. This event validated CreekDog's mission to engage and empower citizens to take action to report on serious pollution issue throughout the watershed. The following pages show the reporting of Issue 82 and responses from both the West Virginia (fig.4.6-7) DEP and Morgantown Utility Board (fig.4.5).

\section{s. CreēkDog \\ Be a watershed watchdog.}

HOME

REPORT AN ISSUE

CURRENT ISSUES
POLLUTION GUIDE

FRIENDS OF DECKERS CREEK

Current Issues

Construction Stormwater

\section{3-04-20}

There is a manhole cover visible from the South High Street Bridge near the Monongalia County Board of Education Office that has visibly overflowed what seems to be chemicals and paint which have then presumably washed into Deckers Creek. This could be due to a combination of heavy rain recently as well as from construction runoff from the projects at Morgantown High School. It seems as though the construction site may have been rinsing equipment and brushes off directly into storm drains which is against ordinances as it would affect water sources in the area. This Report has been Closed

View detail page

Trash

2012-09-25

Major, very large, very deep Trash Dump Site. Found during FODC trash pick-up on September 23,1012 . Found in ravine near double culvert alono stream bank. Bv the. lonks of it is several Friends of Deckers Creek CreekDog

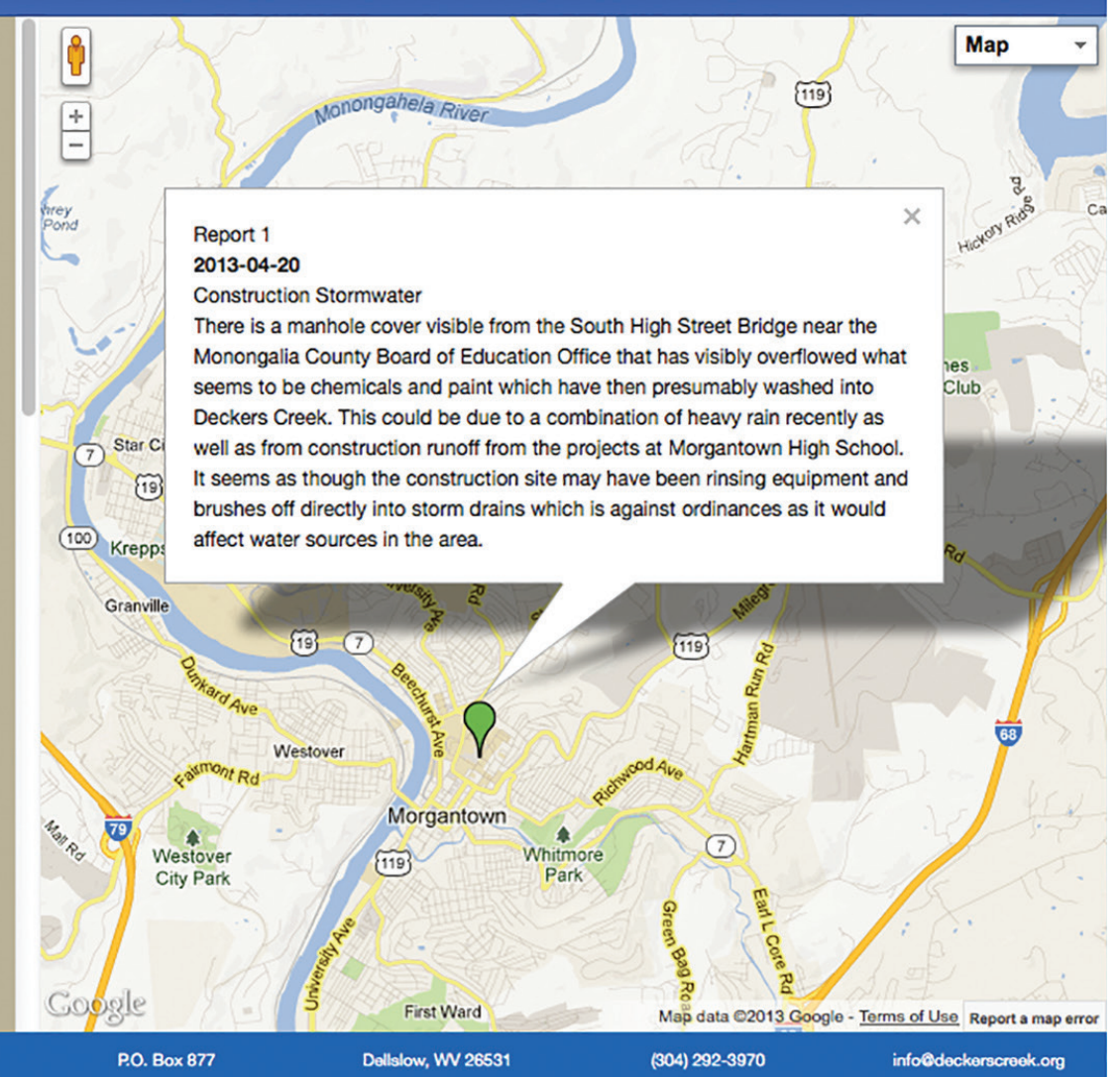

Figure 4.4: Screen shot of CreekDog Issue Report 82 


\section{Construction Stormwater Pollution Issue}

5 messages

F. T. Conroy <forrest.conroy@gmail.com>

To: cdale@mub.org

Sun, Apr 21, 2013 at 5:25 PM

The following issue was reported on CreekDog.org. Could you look into this issue?

https://maps.google.com/maps?q=39.6339371,+-79.9525196

http://www.creekdog.org/report/82/

\section{Issue Report 82}

Created: $2013-04-20$

Type of pollution found: Construction Stormwater

Description: There is a manhole cover visible from the South High Street Bridge near the Monongalia County Board of Education Office that has visibly overflowed what seems to be chemicals and paint which have then presumably washed into Deckers Creek. This could be due to a combination of heavy rain recently as well as from construction runoff from the projects at Morgantown High School. It seems as though the construction site may have been rinsing equipment and brushes off directly into storm drains which is against ordinances as it would affect water sources in the area.

Longitude: -79.9525196

Latitude: 39.6339371

Chris Dale <cdale@mub.org>

Fri, Apr 26, 2013 at 9:14 AM

To: "F. T. Conroy"<forrest.conroy@gmail.com>

Mr. Conroy,

I apologize for taking so long to get back to you and appreciate your patience. MUB investigated the matter you brought to our attention and corrected a sewer blockage (due to an accumulation of grease) at the location on April $18^{\text {th }}$. MUB staff will closely monitor activities in the area for the possibilities of improper construction practices.

Thank you for bringing this to our attention. Should you have further questions or note future issues please do not hesitate to let me know directly. The involvement of community members is integral to protecting our water resources and I sincerely thank you. 
State of West Virginia

Department of Environmental Protection

Environmental Enforcement

Incident/Investigation Report
REF\#

County Monongalia

Basin_Monongahela

WRC $\square$ sWC $\square$ Spill $\square$ Fish Kill $\square$ By-Pass $\square$ Other $\square$

Received by Chuck Joseph Date 4-22-13 Time 0736hrs

Caller F.T.Conroy Representing Creek Dog/Friends of Deckers Creek

Phone Number N/A Address forrest.conroy@gmail.com

Description of Incident There is a manhole cover visible from the South High Street Bridge near

the Monongalia County Board of Education Office that has visibly overflowed what seems to be chemicals and paint which have then presumably washed into Deckers Creek. This could be due to a combination of heavy rain recently as well as from construction runoff from the projects at Morgantown High School. It seems as though the construction site may have been rinsing equipment and brushes off directly into storm drains which is against ordinances as it would affect water sources in the area.

Specific Location Monongalia BOE Building South High St, over bank below bridge

Responsible Party MUB

Date/Time of Incident 4-18-13 Stream Deckers Creek

Material/Quantity Spilled sewage/unknown quantity

Spill status: $\bigotimes$ Stopped $\square$ Clean up in progress $\bigotimes$ Other (list) CleanUp complete

$\square$ Dead fish noted $\square$ Wildlife notified $\square$ Law Enforcement notified

Investigation findings: Received spill report \# 34-233817 (A) Notification of Emergency Spill from WV DEP Inspector Supervisor Kevin Lilly on 4-19-13. It had been forwarded to the wrong DEP Region with the wrong county code. MUB reported the spill again on the $19^{\text {th }}$. According to MUB's Joe Teets, the first day, they hosed the line and unclogged it. They also found the manhole cover in the creek and replaced it. The next day, they sent someone to double check and it was discharging (clogged) again. They unclogged the line and sent a worker into the manhole for inspection. He found a 6 -foot log had been placed into the sewer line. They attributed it to vandalism.

The internet-based reporting system for Creek Dog, a Friends of Deckers Creek program, forwarded a complaint to our Haz Waste section who forwarded it to me on 4-22-13. Since the Creek Dog complaint was more recent, a follow up visit was conducted. No evidence of subsequent discharge was found. The manhole appeared to have discharged and it appeared as though MUB had placed lime around the affected area for disinfection. 


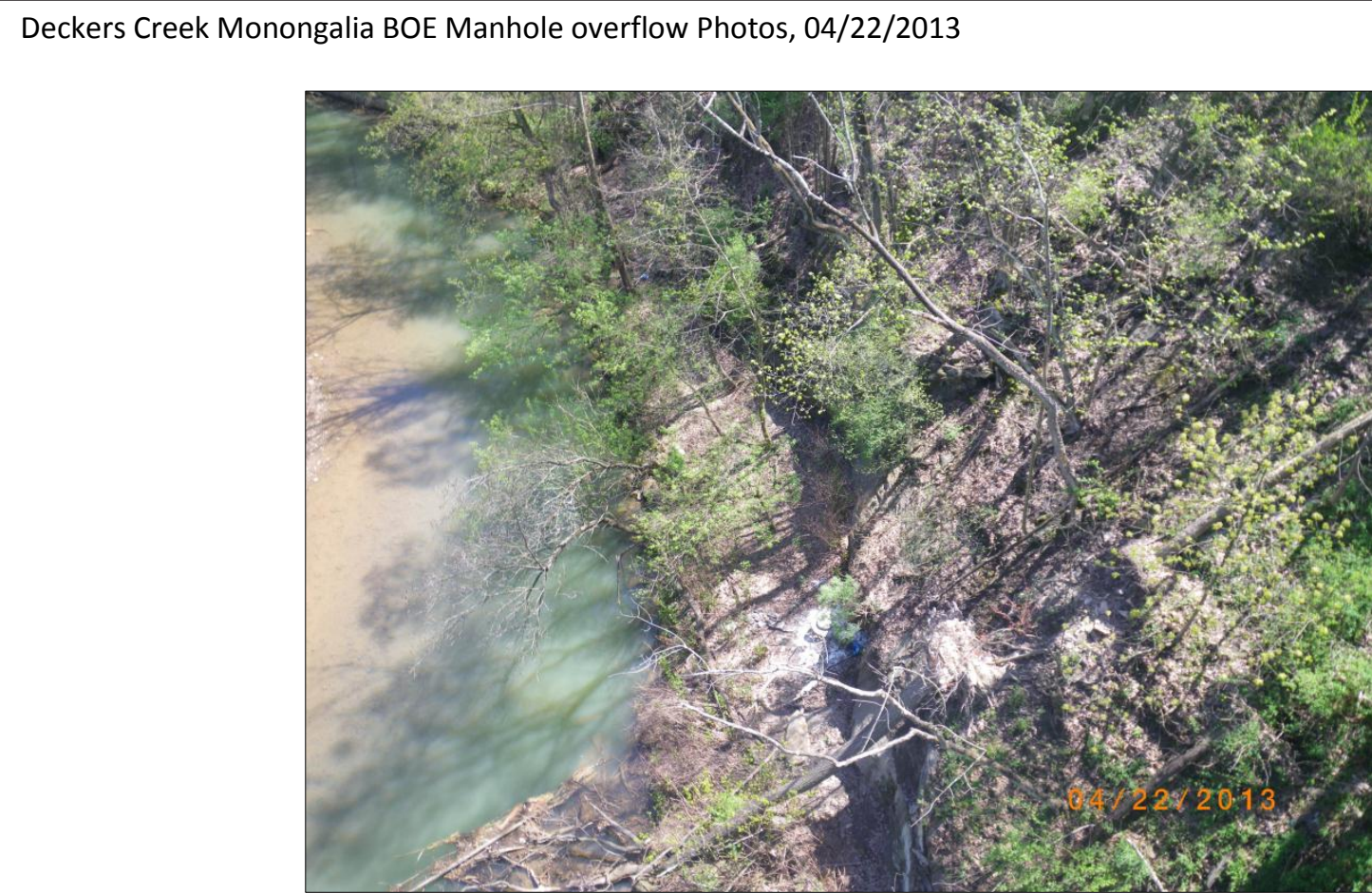

IMGP3305, susbject manhole from South High Street Bridge

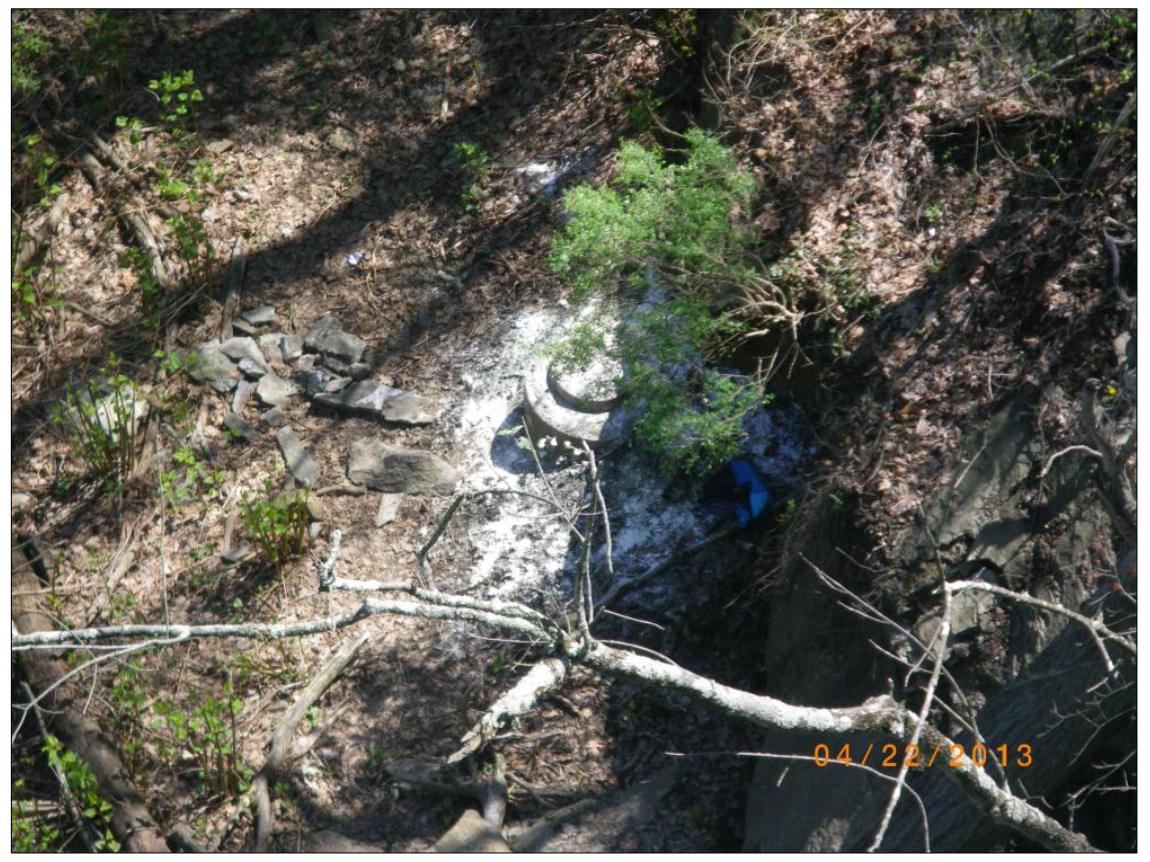

IMGP3306, closeup of subject manhole from South High Street Bridge

Figure 4.7: Incident Report photograph documentation from West Virginia Department of Environmental Protection for CreekDog Issue Report 82 


\section{CreekDog 2.0 and partnership with Appalachian Stewardship Foundation}

The new version of CreekDog (2.0) would improve and build off of the successes of the original. As we continued to use CreekDog to report on pollution violations throughout the watershed, we encountered many challenges. Having discussed the application with users and stakeholders, web developers, and public agencies, we highlighted several opportunities to improve how CreekDog functions and communicates with its audience. This need resulted in applying for and receiving funds through a grant from the Appalachian Stewardship Foundation (ASF). ${ }^{27}$

We sought out funds for further web development, research, custom programming, and redesign of the CreekDog application. A web developer would be contracted with these funds to tackle the complex functionality required of the site.

While the majority of funds would go toward developing technology for the CreekDog application, the additional funds would go towards agency coordination, educational outreach, marketing and promotional materials. This funding would help to ensure that the CreekDog project would be a crossmedia campaign that utilized print, web/ mobile, social, and environmental signage. These materials would be used to educate, inform, and promote the online/mobile tool.

\section{Youth Advisory Board}

The Friends of Deckers Creek Youth Advisory Board (YAB) is an important stakeholder in the mission of FODC and CreekDog. They are currently working towards a youth watershed guide for Deckers Creek called Youth Watershed Connections. The Youth Guide to Deckers Creek, will consist of a website featuring an interactive map of our watershed. The guide will have a general outline of the watershed and include layers with pertinence to topography, hydrology, forestry, recreational activities, and sources of environmental contamination. The creation of this guide will result in our YAB group becoming familiar with the watershed boundaries, hydrology, and forest cover of Deckers Creek. Using the momentum and matching funds of the ASF grant, FODC YAB recieved a grant from West Virginia Geological and Economic Survey (WVGES) to help fund the Watershed Connections project. CreekDog will be the main component of reporting pollution issues in the watershed for this project. In addition to CreekDog they are also partnering with Full Steam Labs and National Geographic Education. ${ }^{28}$ A major focus in this educational component are leadership skills and peer mentorship. YAB members will be working to mentor other youth groups to help build their own guides to their home watersheds.

\footnotetext{
27 "Appalachian Stewardship Foundation," http:// appalachianstewards.org/.(accessed April 27, 2014).

${ }^{28}$ Friends of Deckers Creek, post to Friends of Deckers Creek Facebook page, February 6, 2014 (5:17 p.m.), accessed April 27, 2014, https://www.facebook.com/ friendsofdeckers/posts/675388689166633
} 


\section{Further Web Development}

The newest version of CreekDog (fig.4.8) improves and builds off of the successes of the original. As we continue to use CreekDog to report on pollution violations throughout the watershed we have encountered many challenges along the way. Having discussed the application with current users and stakeholders, web developers, and public agencies, we have highlighted several opportunities for improving how it functions and communicates with its audience. While discussions with these groups continue, we will highlight some of the application's most important needs.

\section{Improving Reporting and Expanding Communication}

- General improvements to functionality and information provided to the 'watchdog.'

- Expanded improvements in communication by sending, sharing, and responding to pollution issues.

\section{Responsive Redesign}

By reconstructing CreekDog as a responsive site (fig.4.9) we eliminate the need for two different versions, both web and mobile sites (fig.4.2). Crafting an adaptable and responsive site will provide an optimal viewing experience across all devices will make it easier to read and navigate. The first version contains multiple scripts for both the web and mobile sites. By combining both into one holistic site we are able to manage conflicts between versions. The responsive site allows us to customize, combine, create, and manage code, which leads to increased functionality for all devices. One important example is the creation of geolocation recognition.

\section{Geolocation Recognition}

Geolocation is the identification of the realworld geographic location of an object, such as mobile phone or an Internet-connected computer. Having the site be able to assess the actual location allows us to mark the users' precise location on the map itself (fig.4.12), adding an essential element of functionality to creating the report page. By marking geolocation, a more effective report is created because the user doesn't have to search the map for their current location. It also helps to orient users to the map and creates fewer location errors when reporting and increases the public agencies' ability to take effective action by using reports from a precise user location.

\section{CAPTCHA: Telling Humans and Computers Apart Automatically ${ }^{29}$}

The first issue of CreekDog relied on a moderator to accept and post issues once they've been reported. Myself and Friends of Deckers Creek are the current moderators for reports. In the last iteration, this filter was essential to preventing the application from being gamed and spammed. Without it, computers (bots) and not humans, were able to create reports and apply posts to the map. What was needed is a layer of security to ensure the integrity of the application. Security becomes critical to the mission and goals of the CreekDog.

A CAPTCHA is a program that protects websites against bots by generating and

29 "CAPTCHA: Telling Humans and Computers Apart Automatically," http://www.captcha.net/.(accessed April 27, 2014). 
grading tests that humans can pass but current computer programs cannot. For example, humans can read distorted text as the one shown below, but current computer programs cannot. The addition of CAPTCHA (fig.4.10) may alleviate the need to have a moderator for the reports. Moderators are still needed to ensure that people are reporting in a responsible manner. However, this will allow reports to appear on the Current Issues Map immediately and subscribers, such as agencies, will get the report without delay.

\section{Creating Dialogue: Social Media Integration, Sharing, and Commenting}

By improving the overall reporting experience and building a more direct communication line with both public agencies and the citizen watchdogs, CreekDog is able to be an effective and essential tool to combat pollution in the Deckers Creek Watershed. In addition to communicating with these current stakeholders it is important to raise a more global consciousness of the CreekDog application and the Deckers Creek Watershed. We want CreekDog to have a stronger connection to social media (fig.4.13). A public Facebook page was created and we have created the opportunity to share reports via Facebook and Twitter from the CreekDog site, as well as other forms of media. This gives us the opportunity to spread the word throughout the community about pollution issues and provides citizens with the opportunity to show how they've made a positive impact in their communities. Creating an discussion and dialogue around these issues helps to build community affinity with the CreekDog brand and the FODC organization. Another way we have increased dialogue around issues is by adding a comments section to each report that is created (fig.4.13). Reporters provide additional details about a particular issue. The comments section also creates a public forum for the agencies and citizens to answer and ask question regarding issues. These agencies will now be able to provide the public with information about how issues are dealt with, the steps it took to fix the reported problem, and what that means for future issues. This platform provides the opportunity to create educational experiences through continued dialogue. 


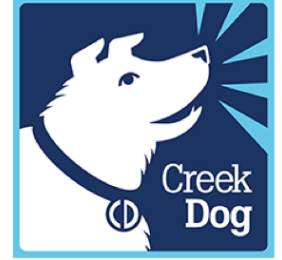

Be a Watershed Watchdog!

Help protect and preserve

the Deckers Creek Watershed by

reporting on serious pollution

issues.

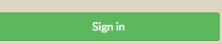

Signin

\section{What is CreekDog?}

CreekDog is an easy-to-use tool for watershed watchdogs. Report watershed pollutants such as trash, untreated sewage, suspicious drilling activity, or stream or wetland dredge and fill. Locate and report on pollution in the Deckers Creek watershed using CreekDog and we'll help you get the word out to the appropriate agencies in the Monongalia and Preston Counties, WV. With CreekDog you can also see what other people have reported.

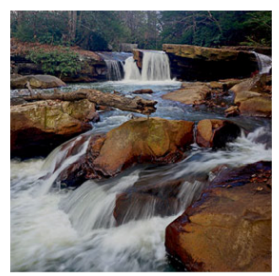

Special Thanks

CreekDog was created

in partnership with

Creek and in part of a grant from the

Appalachian Stewardship

Foundation.

\section{CreekDog}

Triends of Deckers Creek

ב info@deckerscreek.org

(304) 292-3970

P 1451 Earl Core Rd., Suite\#4 Morgantown, WV 26505

@ 2014 CreekDogorg

Figure 4.8: CreekDog Home Page

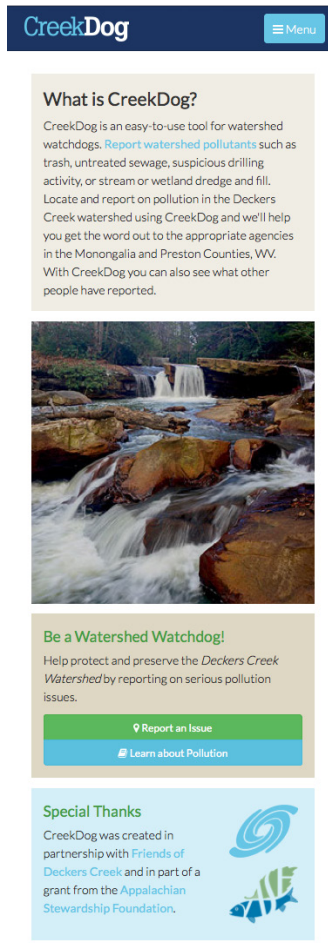

CreekDog

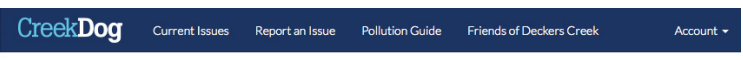

\section{What is CreekDog?}

CreekDog is an easy-to-use tool for watershed watchdogs. Report watershed poll utants such as trash, untreated sewage, suspicious dril ling activity, or stream or wetland dredge and fill. Locate and report on pollution in the Deckers Creek watershed using CreekDog and we'll help you get the word out to the appropriate agencies in the Monongalia and Preston Counties, WW. With CreekDog you can also see what other people have reported.
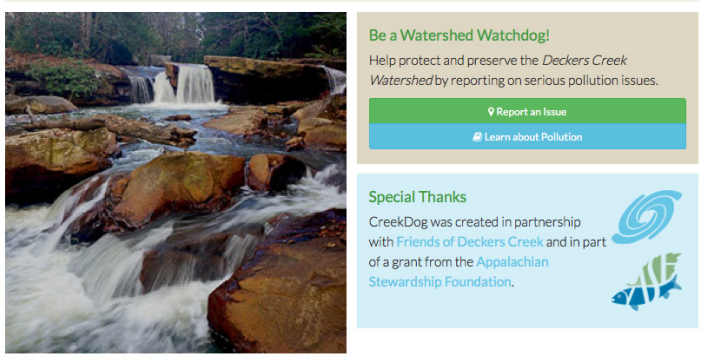

\section{CreekDog}

Friends of Deckers Creek

info@deckerscreek.org

( 1304$)$ 292-3970

P 1451 Earl Core Rd,. Suite \#4 Morgantown, WV 26505

Q 2014 CreekDogorg 


\section{CreekDog Current Issues Report an Issue Pollution Guide Friends of Deckers Creek}

\section{Create an Account}

Your information will remain anonymous for reportingissues. Sign up to keep track of your

Your information will remain anon
reports and receive notifications.

Emall
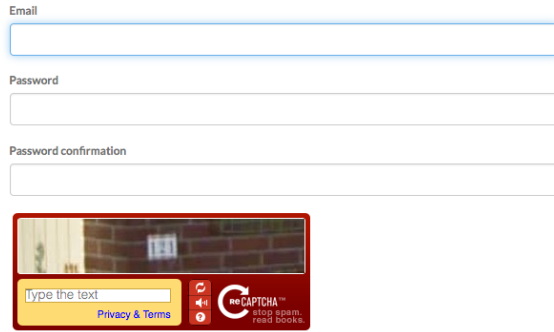

Create Account

info@deckerscreek.org

(304) 292-3970

P 1451 Earl Core Rd, Suite \#4 Morgantown, WV 26505

๑ 2014 CreekDog.org

Figure 4.10: CreekDog Create an Account page is automatically loaded when the user attempts to report an issue but is not logged in. This also highlights the added security of requiring email, password, and CAPTCHA. This ensures that reports are made by humans and not computers.

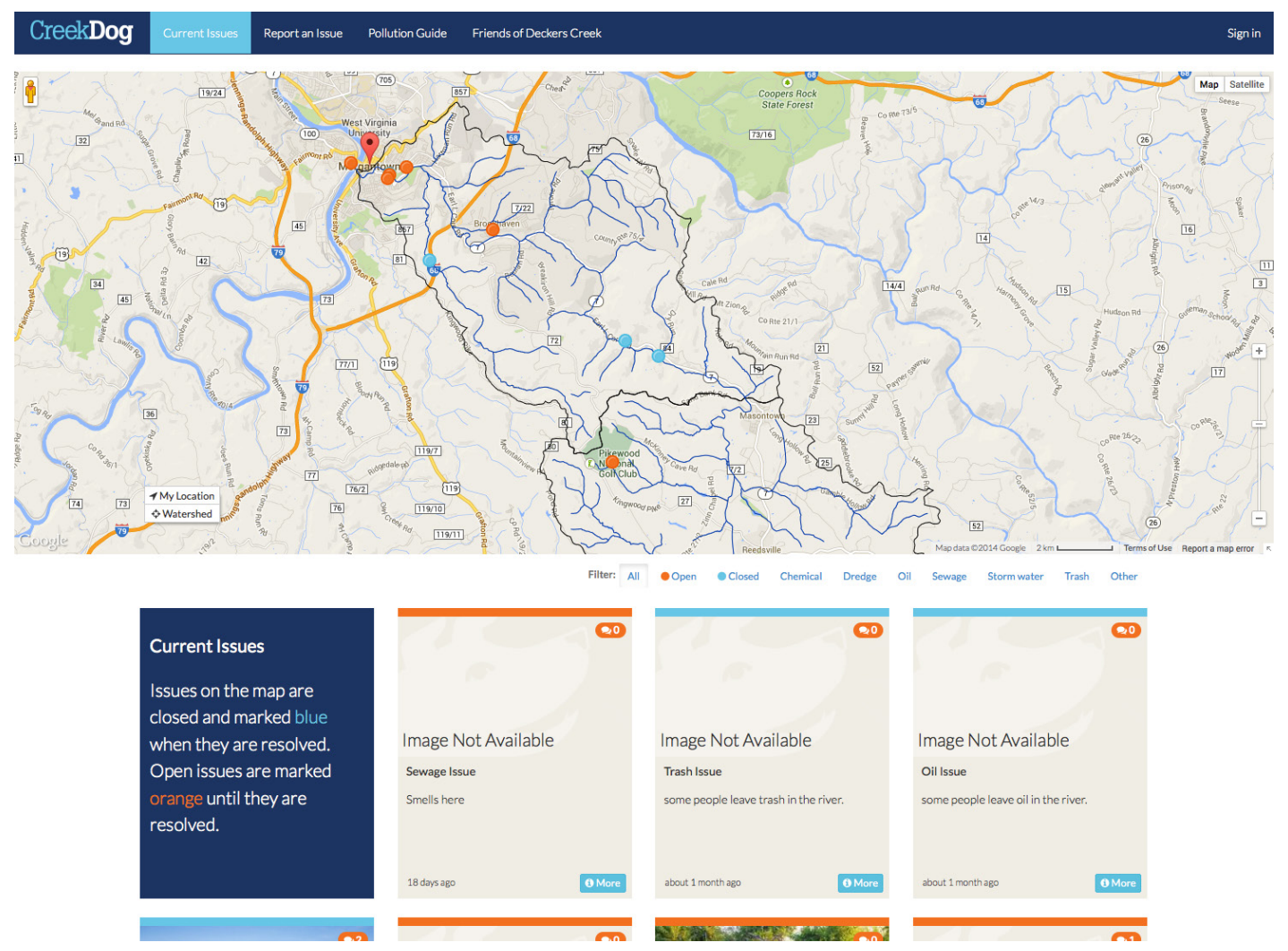

Figure 4.11: This is the Current Issues page. The watershed boundary is highlighted on the map. Open/live issues are coded by orange and closed/resolved issues are coded blue. Filters were incorporated on the map to display issues by category or open and closed issues. 


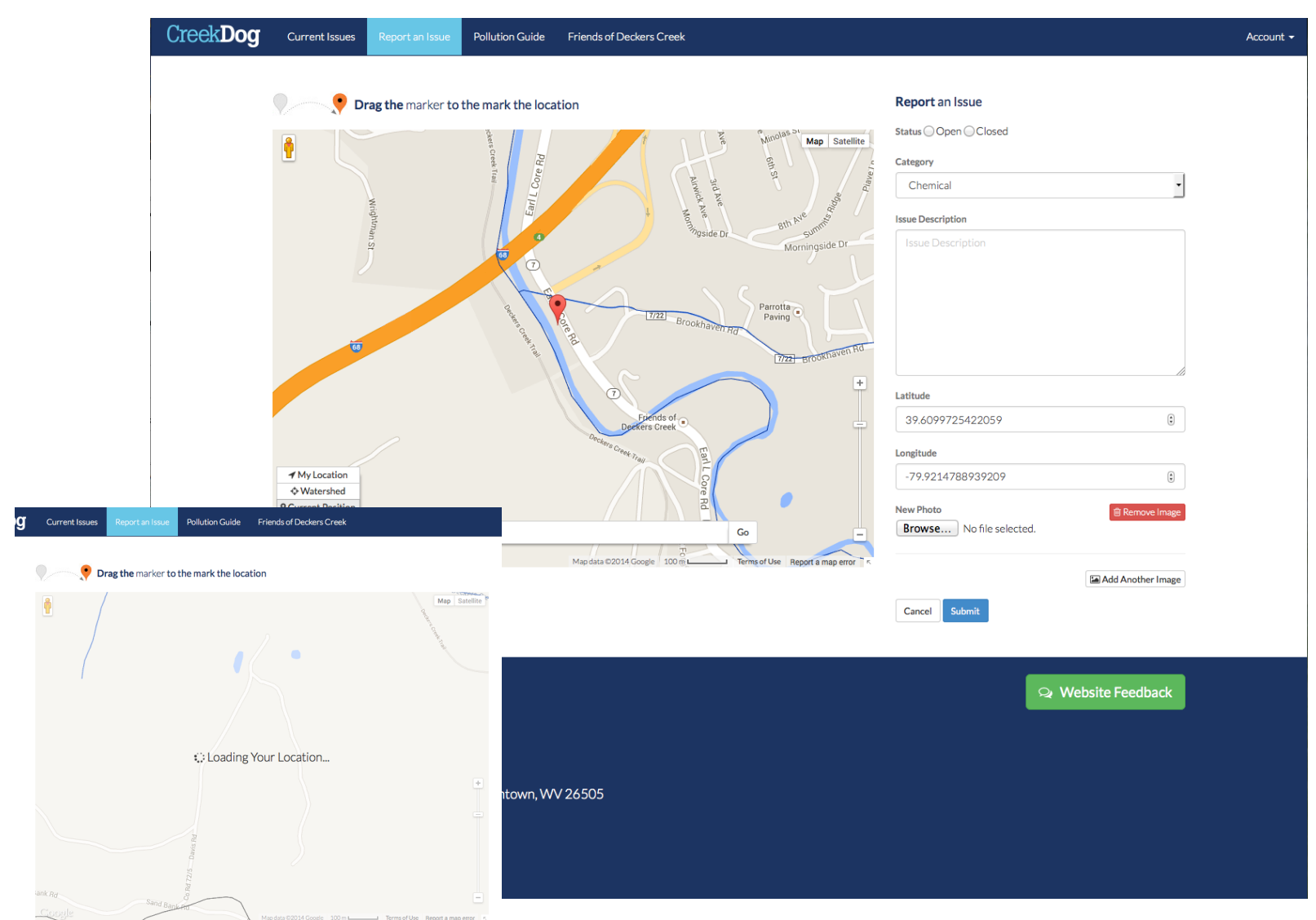

Figure 4.12: CreekDog Report an Issue Page equipped with geo-location recognition providing more accurate location reporting by moving the marker based on current location. This new version allows for multiple photo uploads and allows the user to return to edit the report up to 24 hours after the report is originated.

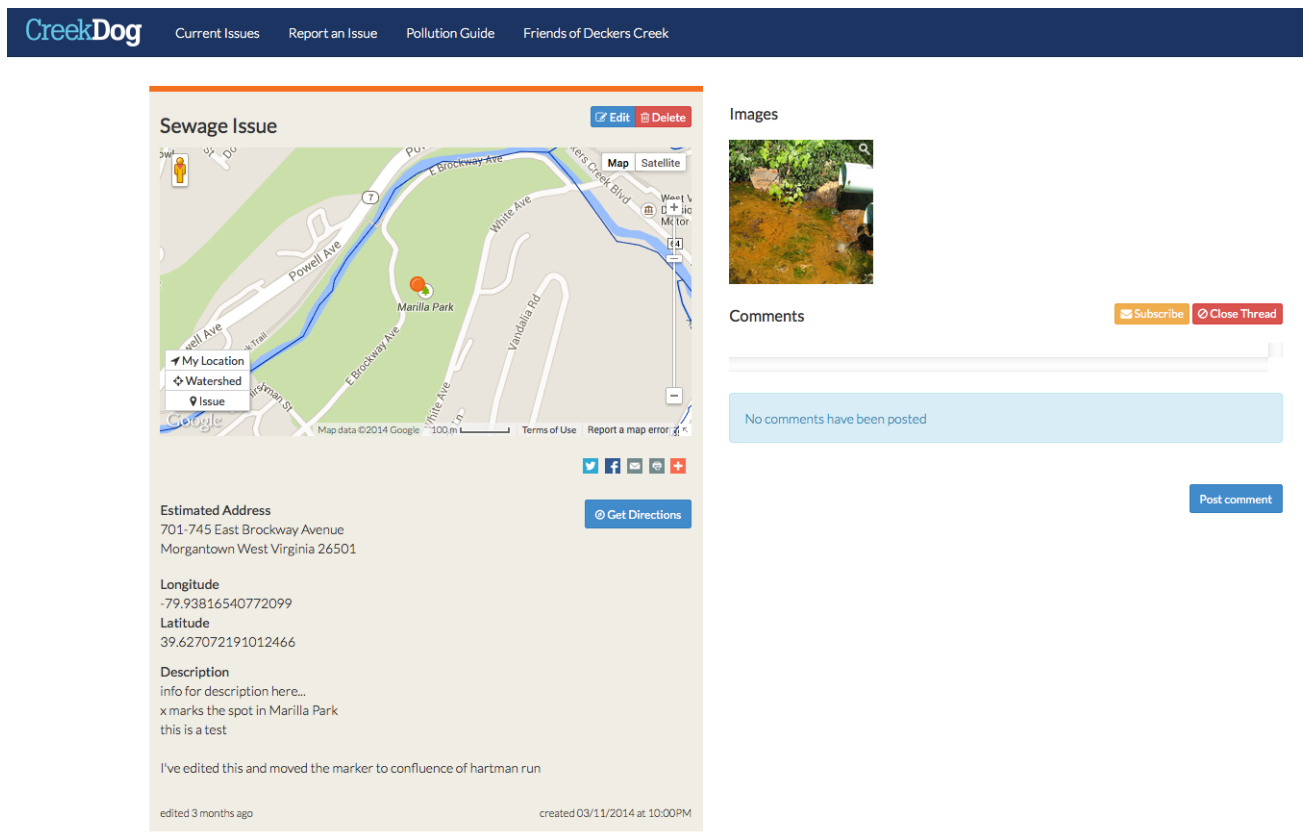




\section{CHAPTER FIVE: Building context and educating the audience}

Educating the audience is an essential component to impacting attitudinal change and fostering opportunities to tackle complex problems. For this project it was imperative we provide citizens an opportunity to navigate the complexity of the problem, see their role in addressing these problems, and feel empowered to take action. One of the best ways to do this was to provide a venue where a context could be built around these issues. For this project, I created an exhibition in the Laura Mesaros Gallery space at West Virginia University's Creative Arts Center.

The goal of the exhibition was to educate and challenge visitors to recognize and understand how personal attitudes and actions are connected to the health of their environment. My goal was to create an educational experience that fostered an understanding of the challenges facing us, to improve the Deckers Creek resource, stimulate a call to action (fig.5.2), and raise peoples' desire to make a difference.

The newest iteration of the CreekDog web site was displayed along with several educational pieces that illustrated the complex issues such as acid mine drainage, sewer overflows, and trash that negatively impact the water quality on a daily basis. The goal was not to simplify these issues, but to make the information comparative and understandable for a wide audience. I also used this wonderful opportunity to share my experience and discovery of the more beautiful aspects of Decker's Creek through photography (fig.5.1). These photographs serve to illustrate the story of the Friends of Deckers Creek organization and their mission to help protect and improve this special place for everyone. The work contained in this gallery was a testament to a collaborative transdisciplinary approach and could not have been created without the guidance of many individuals throughout the community.

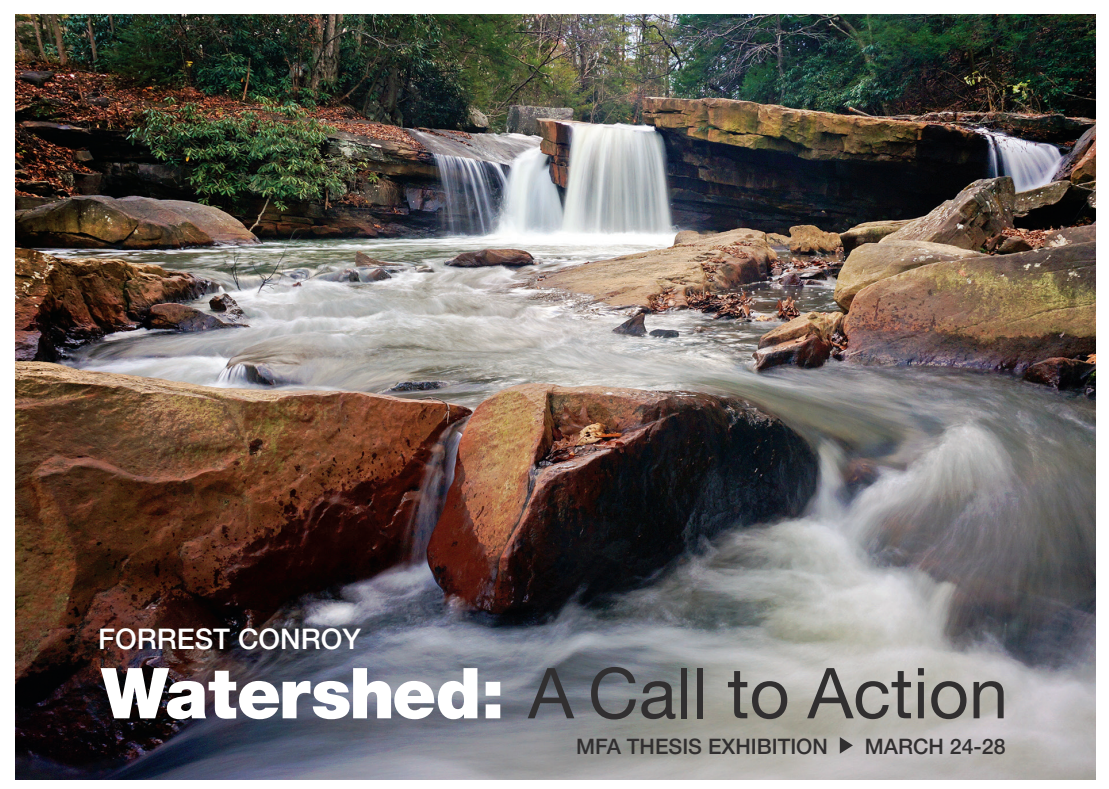

Figure 5.1: Postcard cover announcing MFA thesis exhibition. 


\section{FORREST CONROY}

\section{Watershed: A Call to Action}

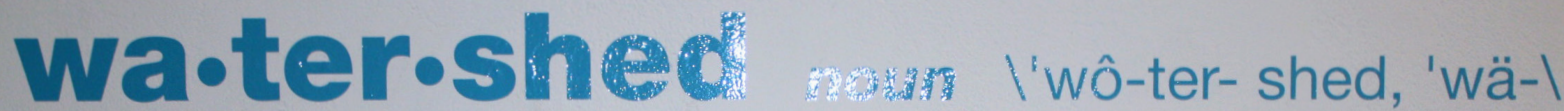

: a time when an important change happens

: a line of hills or mountains from which rivers drain : a ridge between two rivers

: the area of land that includes a particular river or lake and all the rivers, streams, etc., that flow into it 


\section{Waterfall Photographs}

Perhaps the strongest narrative that surrounds the Deckers Creek Watershed is one of both immense beauty and tragic environmental degradation. Many of the most scenic parts of Deckers Creek lie outside of Morgantown and away from the most populated areas. This part of Deckers Creek is not as visible or well known to our audience. Many people only see the most polluted and least scenic portion of the watershed. It was important to highlight the scenic beauty of Deckers Creek to build an emotional connection to the stream. It helps to build a 'sense of place' for our audience and convey the message that this place is worthy of protection and improvement. Waterfalls known as the "Cascades" lie downstream of Masontown, West Virginia. A favorite of whitewater kayakers, these majestic waterfalls are easily accessible from the Deckers Creek rail trail ${ }^{31}$ (fig.5.3). Countless professional photographers have captured these waterfalls. This became a challenge for me because I wanted to not only capture the beauty of the stream, but I wanted to do so in a way that had not been captured before. As a novice photographer, I relied on the advice of professionals to capture these falls with a slow shutter speed and uv filters. I also studied

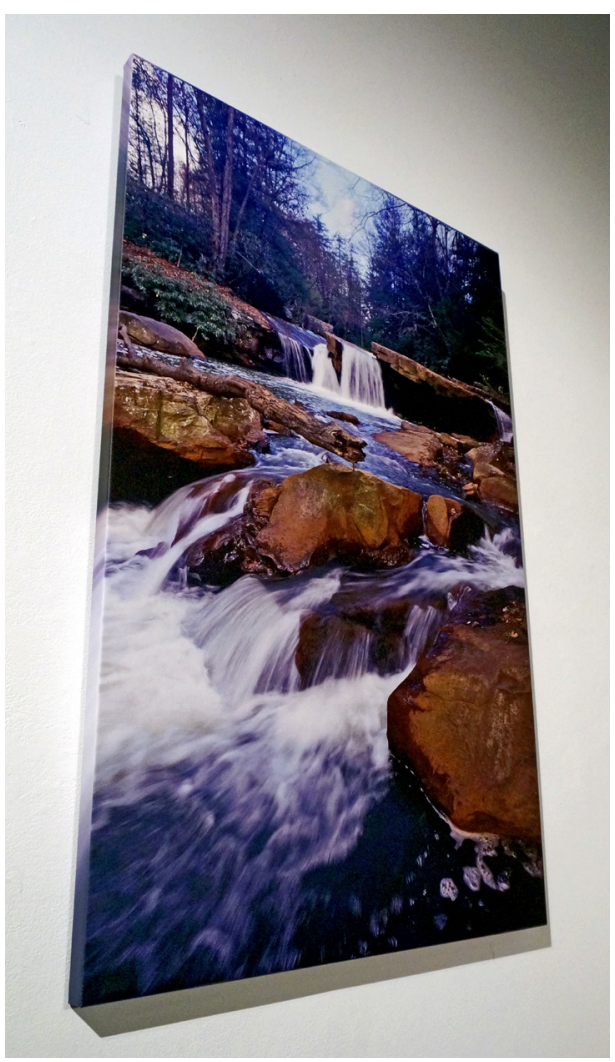

Figure 5.3: This photograph of a Deckers Creek Waterfall photograph introduces gallery visitors to the natural scenic beauty of the watershed. This canvas print was later auctioned off at the Friends of Deckers Creek Spring Meltdown fund-raiser which raised funds to help support staff positions and projects for the year. the angles, perspectives, and times of day, as had many of the professionals photographing the stream. After setting up several test shots, I used a low angle in the middle of the stream to capture the scenes so that the viewer felt immersed in the environment. It places the falls in the center upperthird of the frame and the water zigzags across the frame as it flows over rocks and rushes past the viewer. By making a conscious effort to create a point-of-view that was engaged with the stream, I hoped to bring a sense of immersion to the gallery space. These waterfall photographs were used on postcards and social media to promote the event. They also appeared in the gallery space, on the artist statement, and a large 30 by 48 inch canvas print greeted viewers as they entered the gallery. In terms of hierarchy, this helped set the gallery space up to present the more emotional aspects of the exhibition first.

\footnotetext{
31 "American Whitewater." www.americanwhitewater. org, Deckers Creek, West Virginia, US: Preston Co. line (Upper-Cascades), (accessed May 8, 2014). https://www. americanwhitewater.org/content/River/detail/id/2894/
} 


\section{Photograph Series}

For the gallery space, I felt the need to tell the story of Deckers Creek in ways that I had discovered it myself through my immersive experiences. In many ways this helps to tell the story of some of the transdisciplinary research and methods for the project.

For instance, one of the photo series deals with acid mine drainage in the upper part of the watershed (fig.5.7). Specifically, it deals with remediation efforts that affect Kanes Creek, a tributary of Deckers. This series of photos were taken on a tour of all of the FODC remediation projects in the watershed. Being that I was new to the FODC Board and unfamiliar with all of the projects, I requested a tour. Quickly this generated a lot of interest and soon developed into a tour for the entire board, staff, youth members, and others. We were fortunate to have several experts and students in fields of study such as fishery science, geology, as well as other disciplines. This provided an opportunity to discuss problems and solutions from multiple viewpoints.

This particular photo series was presented adjacent to a larger, information graphic dealing with the Richard Mine (fig.5.19-20). It was intentionally presented this way to contrast the tragedy of an untreated mine like Richard, with one that has been extremely successful. Again, this is an effort to present the efforts that often remain hidden to the greater community. These remediation projects often entail, not just the collaboration of FODC and public entities, but cooperative landowners. As can be seen in the images, these efforts consume a large portion of privately owned land. This photo series provides the science and functionality of a passive remediation system in ways that are not overly technical. At a glance, it tells that the water coming into the system is some of the most acidic and damaged in the watershed. The water is so damaged that it is toxic to most aquatic life. When it leaves the system, it contains an acceptable pH that meets the National Pollutant Discharge Elimination System (NPDES) ${ }^{32}$ permitting standards. ${ }^{33}$

The series tells the story of how partnerships can make a significant impact on a community and helps to build the case for the funding for future projects such as Richard Mine remediation.

Another photo series focused on the FODC Deckers Dash 10K Run fundraiser, and Morgantown's first West Virginia Water Festival (fig.5.6). They both occurred on the same day. On the surface, these were presented to show FODC's connection to the community. It shows the great events that FODC creates for the community. It also highlights the Deckers Creek Trail, their newly renovated Outdoor Learning Park (fig.5.5), and the wonderful recreational activities that contribute to life in this college town. While this serves to promote FODC and future events, it also reveals our personal connection to the watershed. I used these photos to talk about how the health of our watersheds is tied to the health of our communities. A display for CreekDog was created for the waterfestival. As you will read later, this display for the venue provided an open forum to talk about these opportunities and share how they use Deckers.

Fish sampling for FODC's Clean Creek Program also became an excellent opportunity to explore the watershed and engage with multiple disciplines (fig.5.4).

32 "Overview." United States Environmental Protection Agency, Deckers Creek, National Pollutant Discharge Elimination System (NPDES), Last Updated March 12, 2009 , (accessed May 15, 2014). http://cfpub.epa.gov/npdes/

33 Timothy Denicola, FODC Project Manager, e-mail message to author, March 18, 2014. 


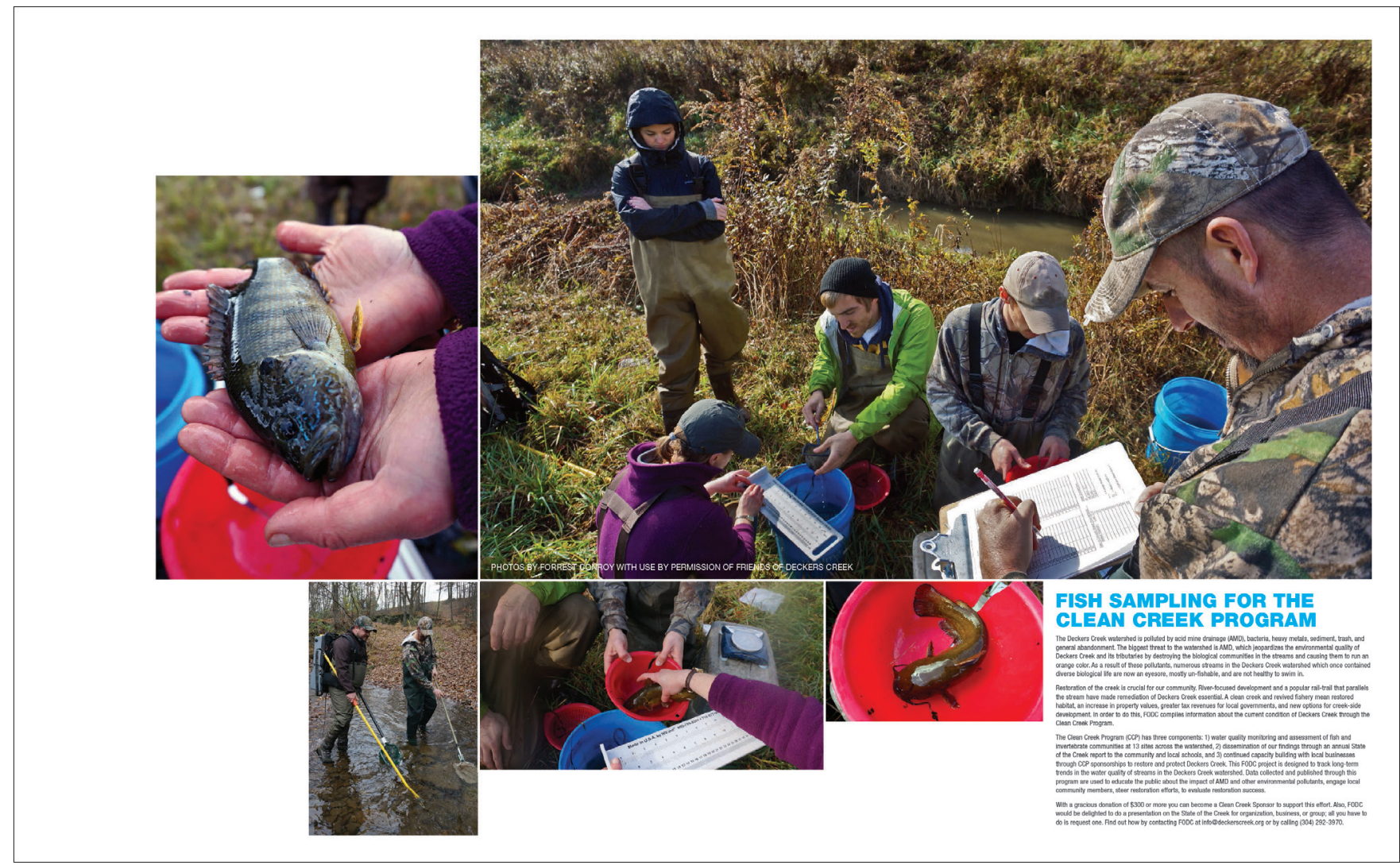

Figure 5.4: Photography series highlighting fish sampling and the FODC Clean Creek Program

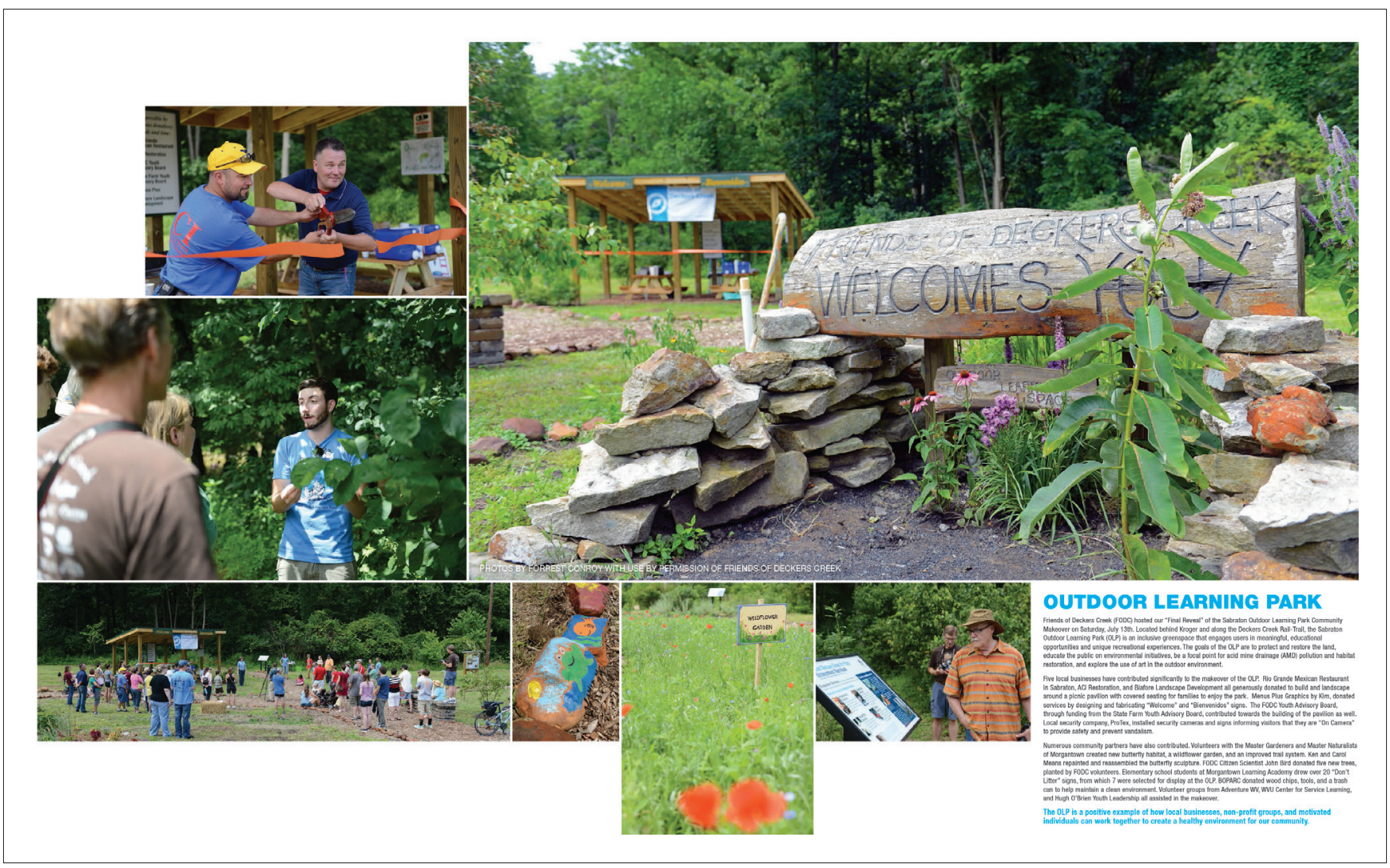

Figure 5.5: Photography series highlighting the FODC Outdoor Learning Park 


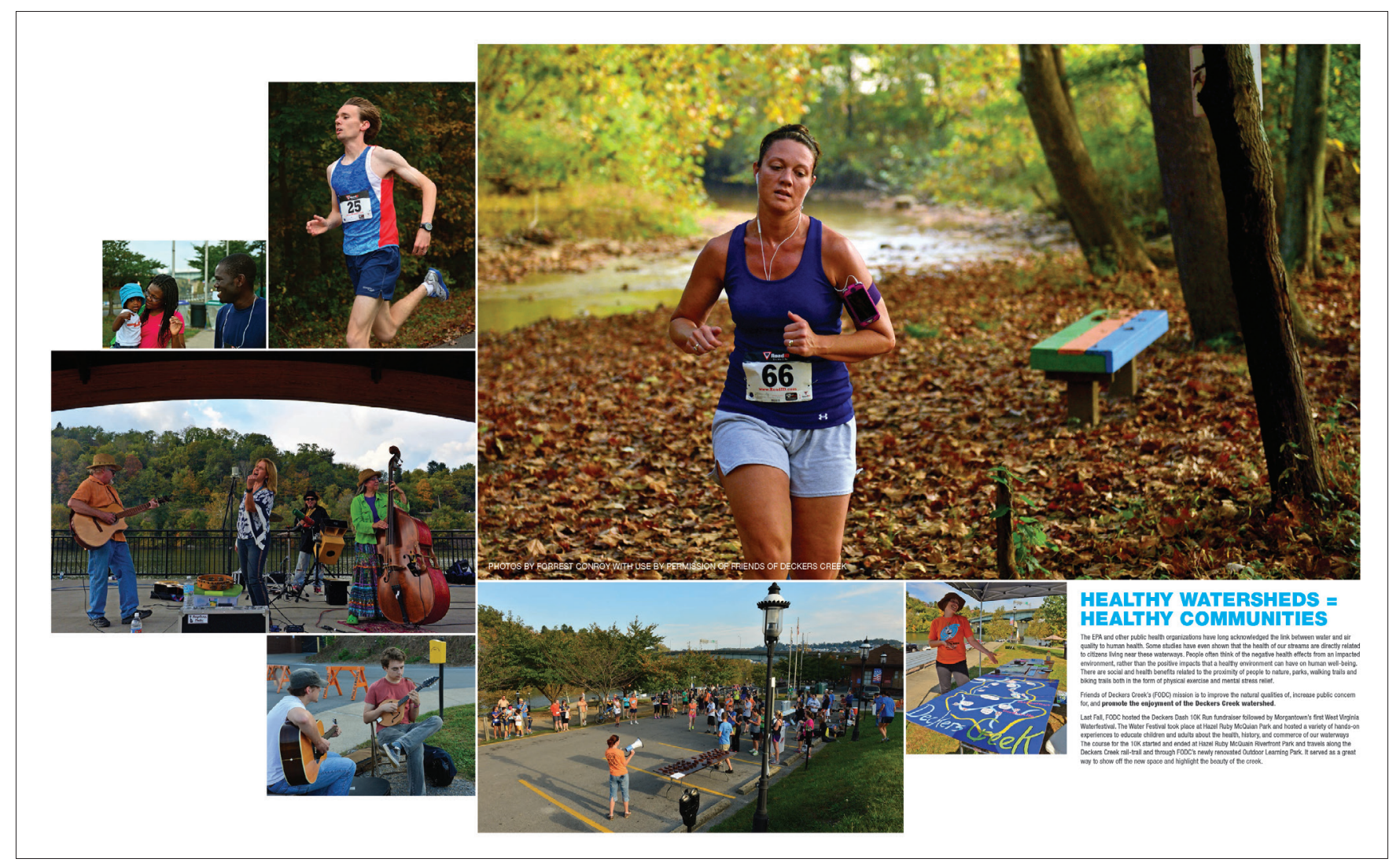

Figure 5.6: Photography series highlighting the FODC Deckers Dash 10K race and Morgantown West Virginia Water Festival

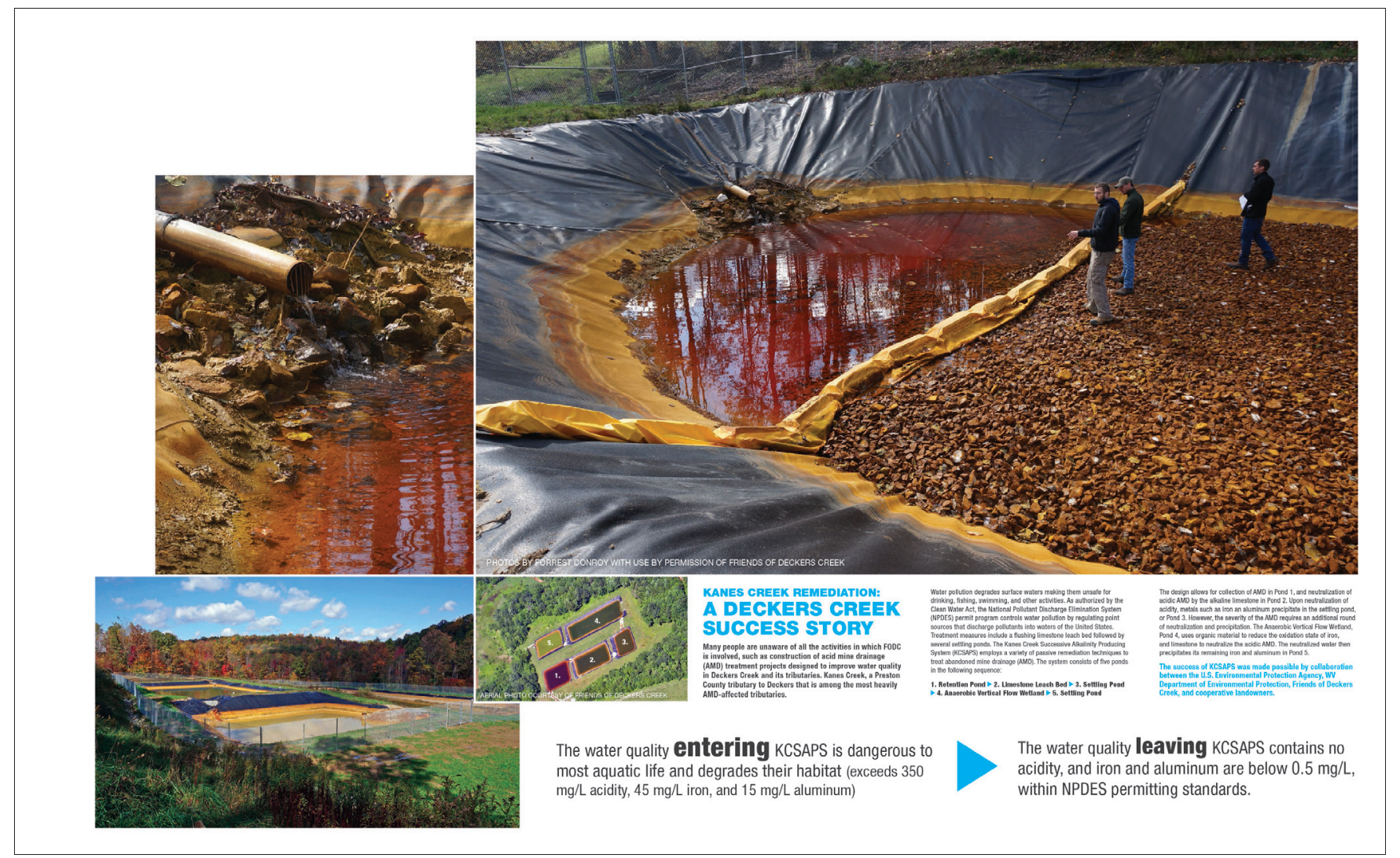

Figure 5.7: Photography series highlighting Kanes Creek, a Deckers Creek tributary, as a successful FODC AMD remediation project. 


\section{Poster}

After showing visitors the beauty that exists along Deckers Creek, it was important to show, on an emotional level, the implications of pollution. I created a poster that used a photograph of the stream taken at Marilla Park (fig.5.8). Marilla Park is part of BOPARC's (Board of Park and Recreation Commissioners) park system that serves the greater Morgantown area. Marilla Park is a 45-acre park situated along Route 7 outside of Morgantown. Deckers Creek runs along the park and the rail trail is accessible from there. ${ }^{34}$ Its location falls downstream from where the Richard Mine discharges acid mine drainage (AMD) into Deckers Creek. This AMD is so severe that it turns the stream bright orange, it decimates the aquatic habitat and makes it difficult for most aquatic life to survive here. ${ }^{35}$ Additionally, pollution from untreated sewage often affects the stream in this section, especially during periods of rain and high stream flows. This pollution is due to several combined sewage overflow systems in the area along with other potential causes. So not only is this area dead to most aquatic life, but it is also unsafe for recreational use. Marilla Park is a prime example of a portion of the stream that is highly visible and accessible but is severely damaged. The purpose of this poster is to show the potential that this stream holds by highlighting the lack of opportunity to be able to fish here. It focuses on the missed opportunity and the void created by severe pollution issues. Silhouettes of two children fishing are cut out of the photograph of the stream, labeled "Marilla Park, Morgantown, WV." Accompanying this image is a personal quote stating, "There is a park in my town and a stream runs through it.
I would love to teach my kids how to fish there, but the stream is dead and unsafe to even play in." Below it has the call-to-action to, "make Deckers Creek 'Swimmable and Fishable" 36 and it provides the FODC website, deckerscreek. org. While it is subtle, this quote borrows from an excerpt (and title) from the Norman Maclean novel, A River Runs Through It. The title of the novel comes from this excerpt:

Eventually, all things merge into one, and a river runs through it. The river was cut by the world's great flood and runs over rocks from the basement of time. On some of the rocks are timeless raindrops. Under the rocks are the words, and some of the words are theirs. I am haunted by waters. ${ }^{37}$

Maclean's novel centers on the narrator's relationship with his brother and their combined love of fishing. While I did not intend for every viewer to understand this subtext, I felt that it was an interesting layer to fold into the meaning of the piece. Part of the meaning of the piece is a personal one - I am both a father of two, and I have a love of fishing. However, I wanted to highlight the true meaning and emotion behind these experiences. For anglers, these experiences are an opportunity to connect with nature, or as Gary Snyder would define it, the wild. But for many, these experiences

\footnotetext{
34 "Marilla Park Information." BOPARC: Board of Park and Recreation Commission, Parks \& Trails, http://www.boparc. org/marilla-park.html, (accessed April 26, 2014).

35 "Friends of Deckers Creek," Richard Mine, http://www. deckerscreek.org/richard-mine/richard-mine-discharge, (accessed June 30, 2014).

36 "Friends of Deckers Creek" www.deckerscreek.org, (accessed April 11, 2011).

37 Norman Maclean, A River Runs Through It and Other Stories. (Chicago, Illinois, Chicago University Press, Ltd., 1976).
} 


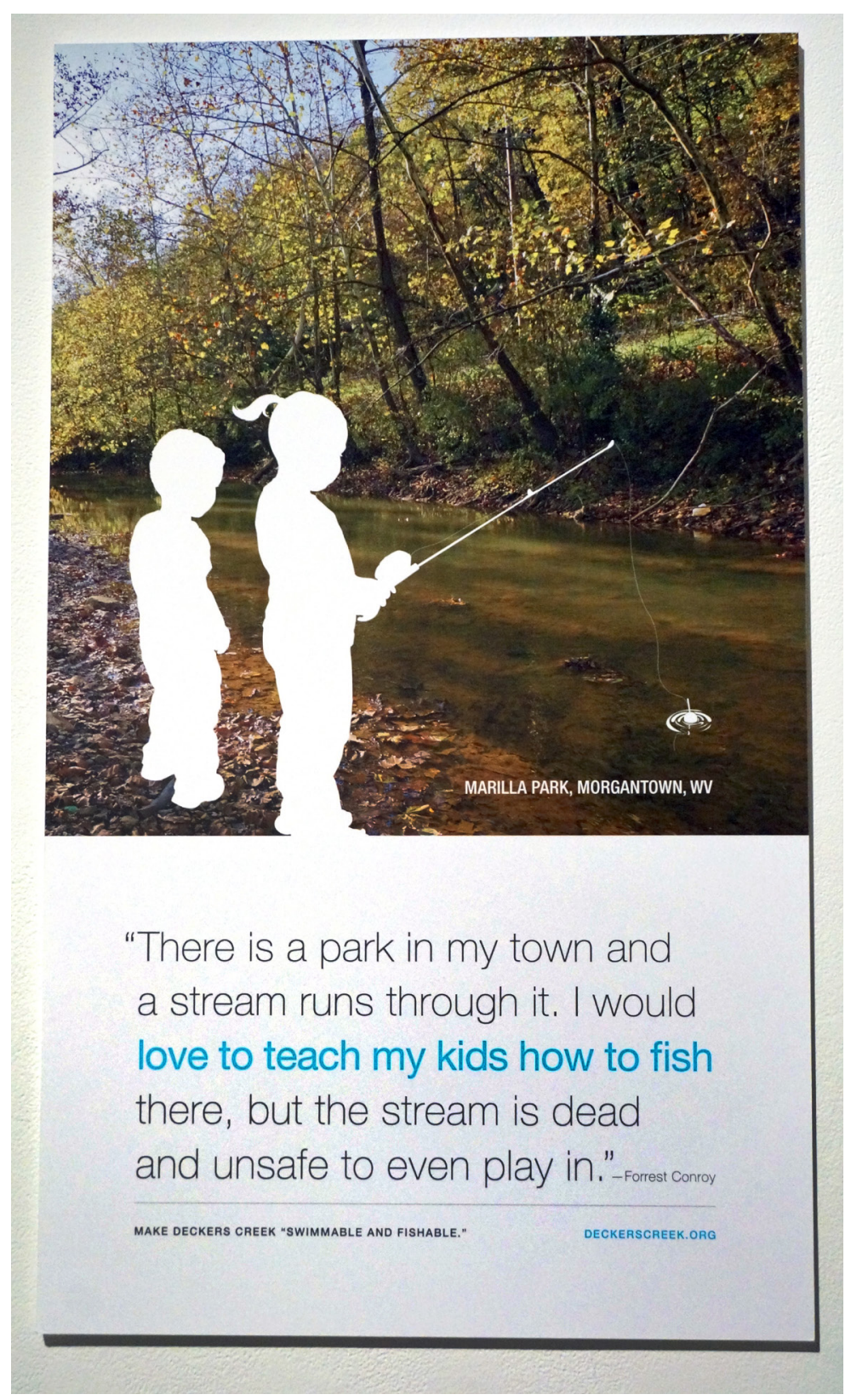

Figure 5.8: Poster appealing to the emotion of gallery visitors, highlighting both the opportunity and impairment of Deckers Creek. also entail a deeper connection our relationships to each other.

Through outdoor recreational activities such as fishing we create bonds and memories with family and friends. By doing so, this place begins to take on a greater meaning. The intent of this poster is to connect with viewers on an emotional level and help build meaning for this place.

This poster could have easily relied on presenting the scientific data surrounding this location along Deckers Creek and the effects of pollution. Disciplinary approaches could have relied on chemistry, biology, or geology but may not be able to make these aspects personal to the viewer. For me, this poster takes all of the research and existing knowledge for this location and turns its current state into a consequence for the viewer - an unrealized opportunity for the viewer. 


\section{Participatory Marble Survey}

Space sculptural pieces were placed throughout the gallery that employed two glass cylinders filled with equal amounts of water and a white box that houses these cylinders filled with blue marbles. The cylinders are bottom-lit with LED lights that illuminate the meniscus. Labeled on the outside of the box is a question, with one cylinder labeled, 'YES' and the other labeled, 'No.' Visitors answer the question by placing a blue marble in one of the two cylinders. These pieces become symbolic of how choice becomes a collection of efforts towards a greater goal. Each choice becomes an action and each action creates a change. By displacement, each marble offered creates an immediate change in the water level, resulting in a visual bar graph.

The first question that visitors come to in the gallery space asks, "Do you know how to report a serious pollution issue?" (fig.5.9) By preceding the other pieces in the gallery space this question helps to set up the informational pieces and the CreekDog website. This question intends to resonate with visitors as they proceed through the gallery space. Information graphics that follow provide answers to this question and provide action items to combat pollution.

The second question sits at the end of the gallery space and asks, "Would you take action to report a serious pollution issue?"(fig.5.10) This question follows the other pieces in the space and serves to resonate with the visitors after they leave the gallery, armed with a greater knowledge about pollution and the ways they can take action on these issues. They also leave with CreekDog, a tool that helps to facilitate this action.

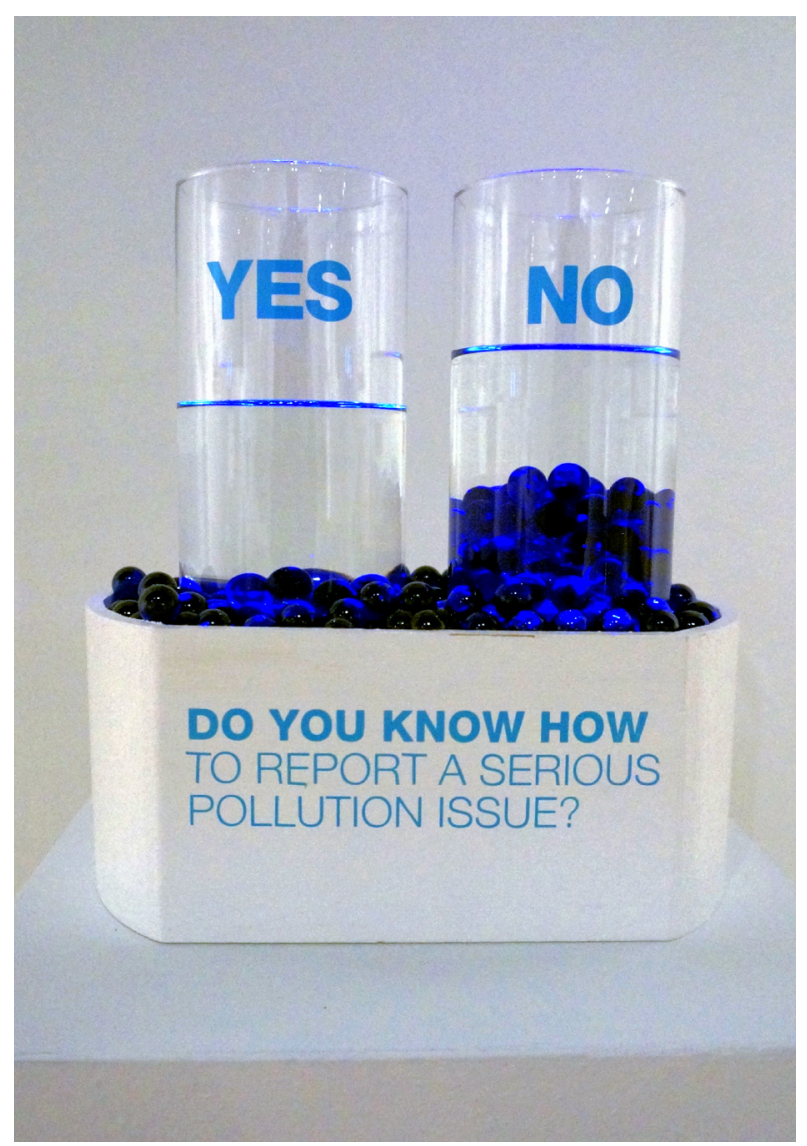

Figure 5.9: Do you know how to report a serious pollution issue? Participatory Marble Survey. This interactive piece displays a physical bar graph of knowledge of visitors to the gallery space.

While these pieces act as a survey to measure the visitors' knowledge, attitude, or intention, they also serve to affect an action in the visitor. This challenges the traditional proclivities of gallery goers to not interact with the installation and provides the audience with a newfound sense of freedom. By making these pieces interactive, visitors become an active part of the exhibit helping create a sense of community within the gallery space. 


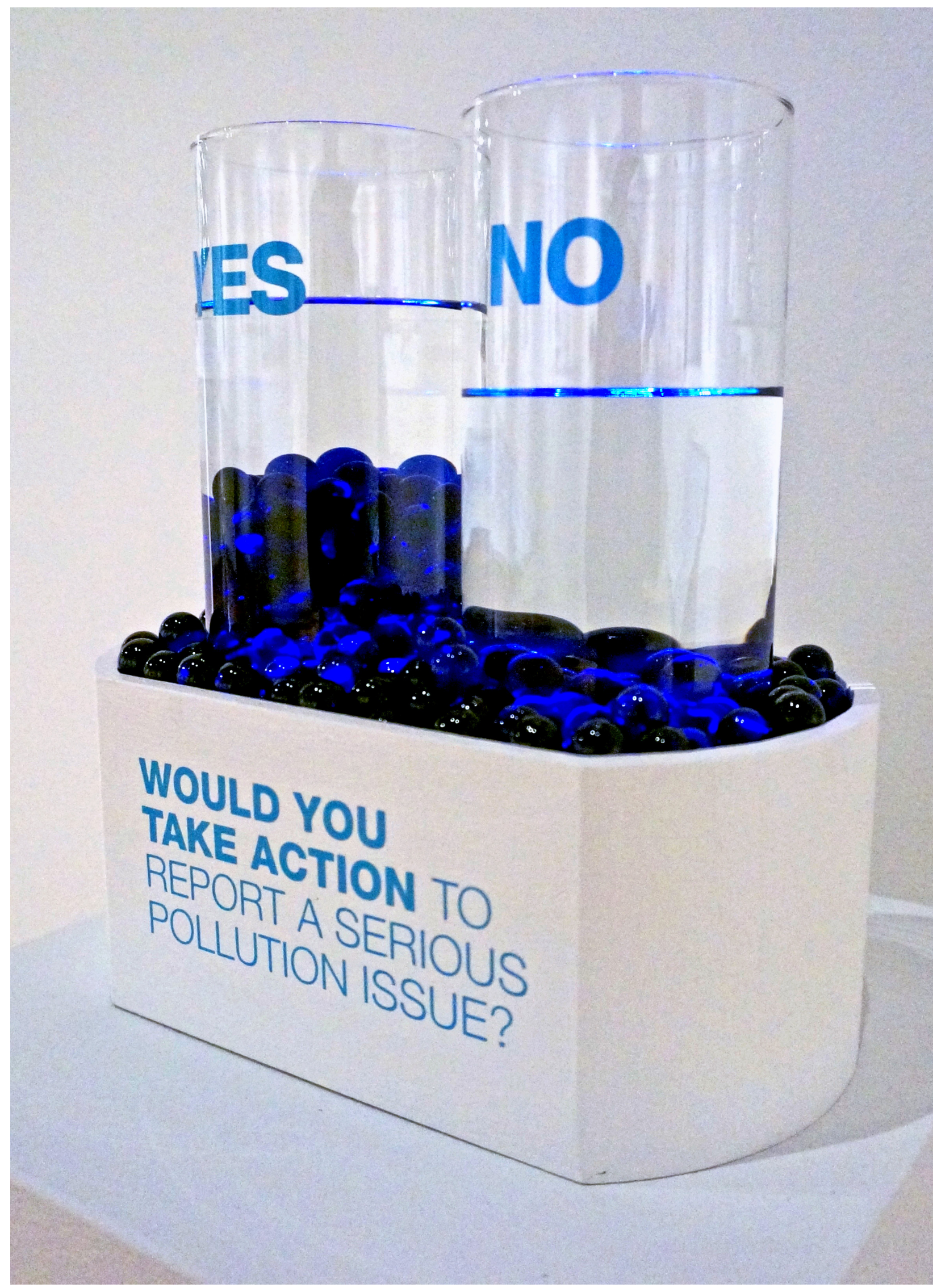

Figure 5.10: Would you take action to report a serious pollution issue? Participatory Marble Survey. 
By creating a conscious effort towards personal action, these pieces become self-reflective. This causes us to contemplate our personal connection and our responsibility to protect the watershed. Collectively it also helps to symbolize how these personal efforts combine to create a larger community effort. The blue marbles also hold symbolic meaning. The blue marble is also synonymous with a famous NASA photograph (fig.5.11) taken by the Apollo 17 crew as they approached the moon. ${ }^{38}$ Thus, marbles are representative of the earth and a holistic perspective.

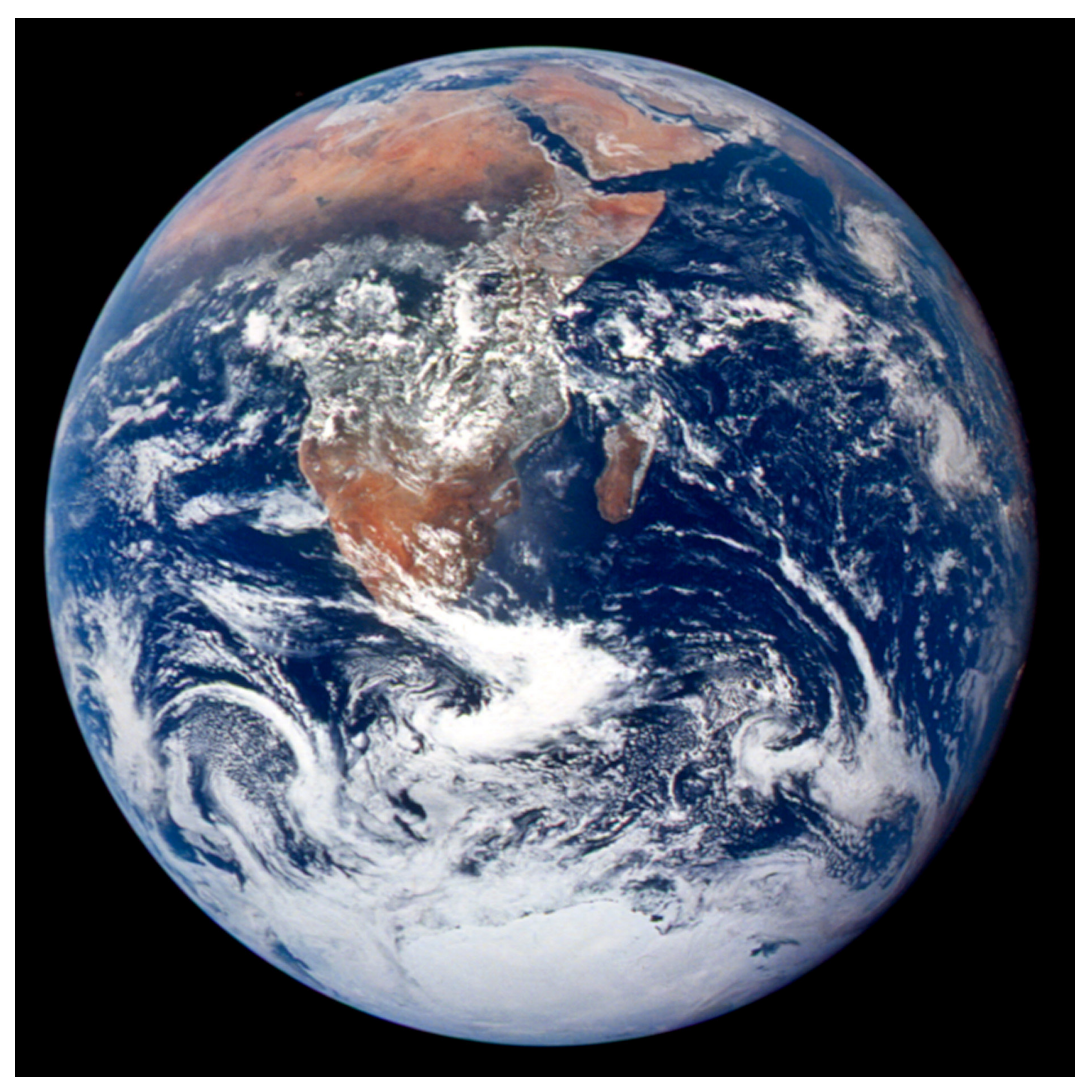

Figure 5.11: NASA Apollo 17 Crew Photograph of Earth, 1972

The "ripple effect" created when the marble is dropped into the water also becomes a symbolic gesture. This symbol represents how good deeds and charitable actions create a broader influence across a community.

\section{Tally of votes for entire exhibition (one week):}

Do you know how to report a serious pollution issue?

Total votes: 216

Yes: 62

\section{No: 154}

Would you take action to report a serious pollution issue?

Total votes: 241

\section{Yes: 187}

No:54

38 Astronaut photograph AS17-148-22727, African Continent, Blue Marble, Apollo 17 Crew, acquired December 7, 1972, Apollo - 70mm Camera, NASA Earth Observatory, http://earthobservatory.nasa.gov/IOTD/view. php?id=1133, accessed May 15, 2014. 


\section{Rail Trail Signage}

A popular rail trail, The Deckers Creek Trail, begins at Hazel Ruby McQuain Riverfront Park in Morgantown; the trail parallels

Deckers Creek and scenic byway Route 7 East across 19 miles to Reedsville, WV, in Preston County. ${ }^{39}$ The rail trail provides easy access to the stream for a variety of recreational and commuting opportunities. Kayakers, anglers, rock climbers, cyclists, runners, joggers, pet walkers, hikers, geocachers, and crosscountry skiers all enjoy the benefits of this trail. Points along the trail provide an excellent opportunity to educate trail users.

These members of our audience are high-end users of the watershed, and because they frequent the trail, are most likely to note changes and witness pollutions that directly impact the stream. To engage this audience we use the traditional form of an interpretive sign (fig.5.12) in an unexpected manner. The goals of this sign are to create brand awareness for CreekDog, provide a call-to-action to report pollution, and educate viewers on the pollution threats in their watershed.

Running down the center of the sign in bold letters, we ask the question, "What will you do to be a CreekDog? By calling out to the viewer directly, this question is meant to be confrontational and conversational. The sign uses the brand and defines CreekDog as a "Watershed Watchdog." It calls attention to the variety of activities that bring the viewer to this location; it points out that they have a unique perspective, and calls them to take action. By creating this recognition, we are showing viewers their connection to their watershed and charging them with the responsibility to protect it.

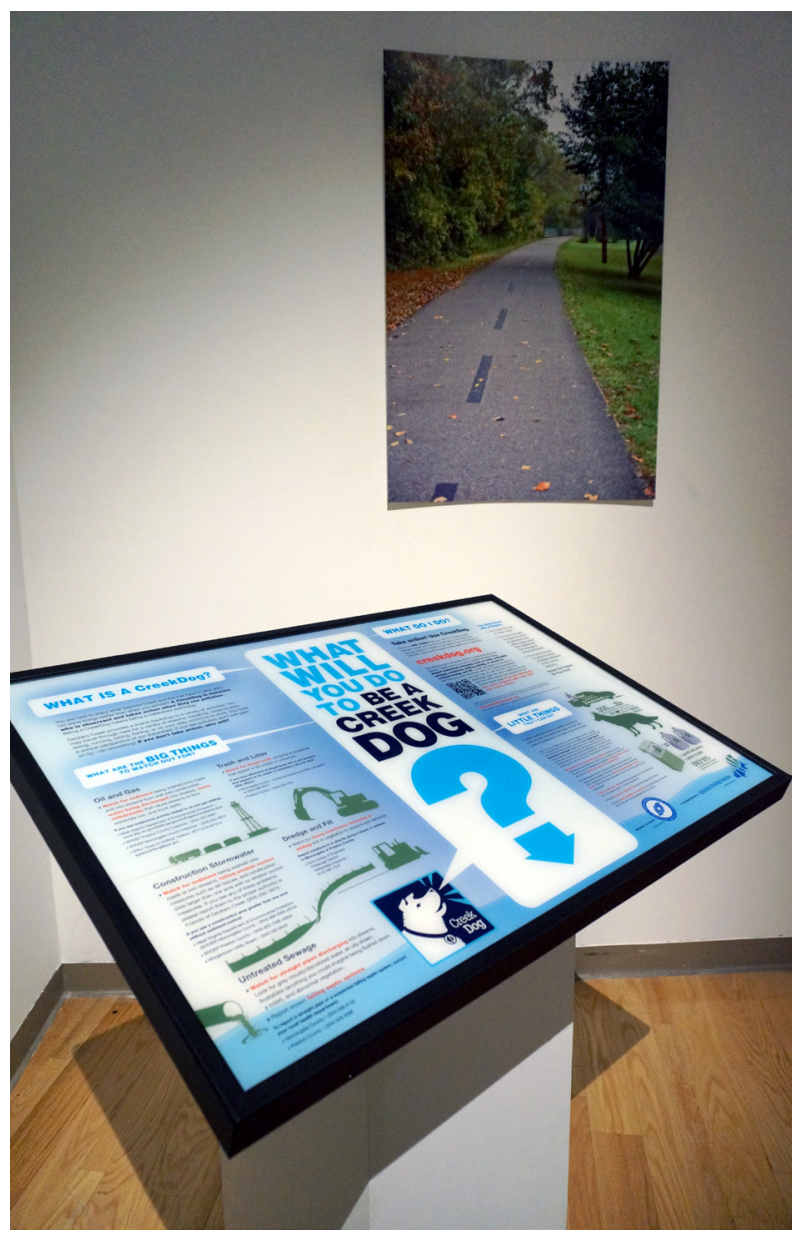

Figure 5.12: Informational Rail Trail Sign promoting CreekDog

Mary Miss's project, FLOW Can you see the river, provided inspiration for this signage. FLOW attempts to make water systems visible to visitors along the White River in Indianapolis, Indiana. ${ }^{40}$

Sited along a 6-mile stretch that extends from the IMA property to the downtown White River State Park, approximately 100 markers situate viewers in the landscape, which includes untamed woodlands, wetlands and a 35-

\footnotetext{
39 " Maps: Deckers Creek Trail," Mon River Trails Conservancy, http://www.montrails.org/maps.shtml, accessed May 15, 2014.

40 " FLOW Can You See the River?," City As Living Laboratory, Framework for a 21st Century City, Sustainablitiy Made Tangible Through The Arts, http:// flowcanyouseetheriver.org, accesed May 15, 2014.
} 
acre lake, and provide information about the significance of each site to the overall ecology of the river. About half these markers take the form of oversized map pins, constructed of steel and painted red, with numbers that allow for dial-up access to brief audio pieces. The other half are circular, stainless steel mirrors atop eyelevel posts onto which are etched informational texts and a red dot. ${ }^{41}$

She says of the project that the river was "bucolic, lovely, a wonderful place to be but people didn't notice it. People weren't paying attention to it very much. It was almost like a hidden asset and that hidden asset turned out to be very polluted." 42 She hoped to engage the audience in the history, ecology, and infrastructure in ways that, "people could come to understand the river more clearly so that they would relate to it in a different way." ${ }^{43}$ Miss's FLOW project served as a great inspiration for these trail signs because it deals with the same problems regarding urban watersheds - Citizens fail to see their connection to these waters; they do not feel empowered to create change, and most of all they do not understand the complexity or severity of pollution.

The CreekDog rail trail sign also educates viewers about their watershed rights, pollution threats, public agencies responsible for addressing these issues, and highlights the things that they can do to help preserve and protect the watershed. These highlights include both large-scale action items and small-scale action items so that everyone leaves the sign with a greater consciousness and sense of responsibility. The sign also contains a quick response code (QR) that they can scan with their mobile device. This provides them with a direct link to the website. Viewers are encouraged to bookmark the link as a quick reference for future use.

\footnotetext{
${ }^{41}$ Susan Snodgrass, "Mary Miss Goes With the Flow," Art in America, News, (September 23, 2011), http://www. artinamericamagazine.com/news-features/news/mary-missfairbanks-art-and-nature-park, accessed May 15, 2014.

42 Stacey Anderson, "Mary Miss:Flow," September 21, 2012, YouTube, http://youtu.be/rCkTZmXR2Nk, accessed May 15, 2014.

43 "FLOW: Can you See the River?," Indianapolis Museum of Art, YouTube, Uploaded October 4, 2011, http://youtu. be/7mJoYbxsCIY, accessed May 15, 2014.
} 


\section{CreekDog Display}

While the goals of the display are to promote the CreekDog brand and inform citizens of their watershed rights, its purpose is also to bridge an emotional connection between citizens and the watershed. Three cube-like talk bubbles, alternate and extend from a pyramidal base. Each side of the cubes asks the question, "What do you see in Deckers?" (fig.5.17) The public is asked to write in permanent marker what they've observed and to share their memories, concerns, and aspirations for the Deckers Creek Watershed. This gives the audience a voice and a platform to publicly share their thoughts.

Building on the design method of brainstorming, I was looking for

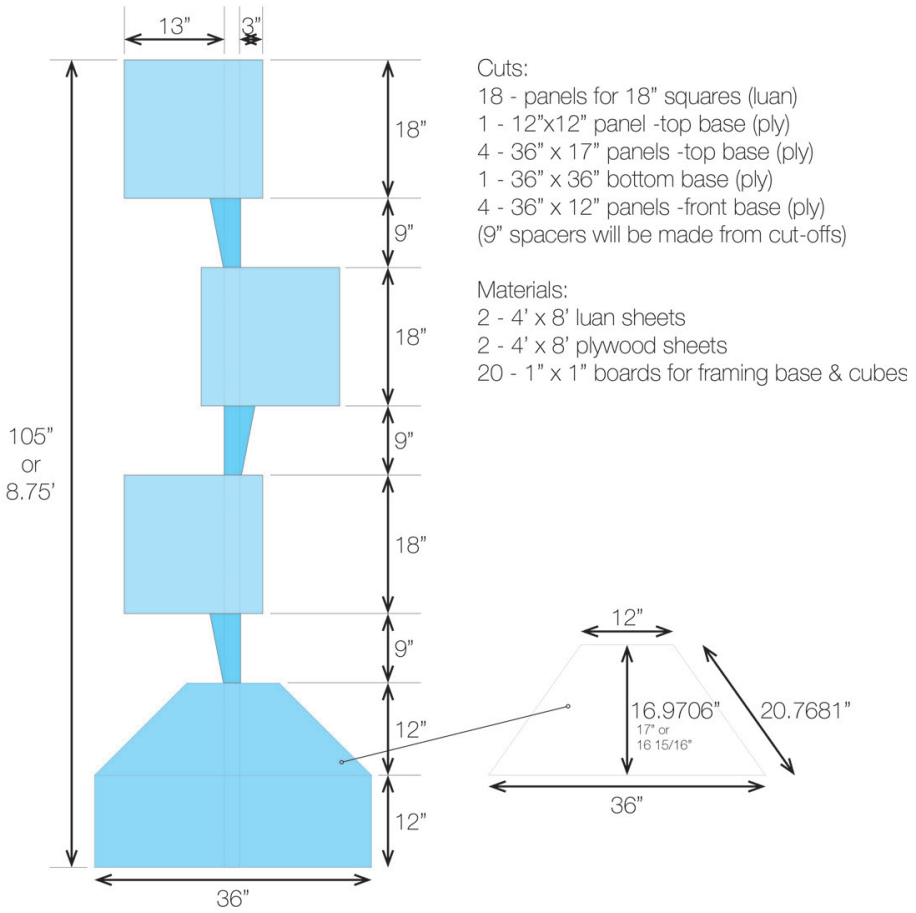

Figure 5.13: Plan drawing CreekDog display construction ways that the community could publicly collaborate and share their ideas. I also like the idea of physical, "interaction," parallel to the idea of interaction used in creating the CreekDog web application. This interaction facilitates action that is analogous for the collaborative approach to CreekDog. It becomes many voices calling out for one cause.

As I was developing the concept for this collaborative display (fig.5.13) I came across artist, Candy Chang. Her work proved to be an inspiration for this piece.

Candy Chang has created works such as "Before I die..." that evokes community members to collaborate and share their thoughts in public spaces. ${ }^{44}$ In her New Orleans neighborhood she covered the side of an abandoned building with

chalkboard paint and stenciled the sentence, "Before I die I want to ." Within a matter of days community members colorfully shared their personal dreams and aspirations in their public space.

According to her TED biography, "Candy Chang is an artist, designer, and urban planner who explores making cities more comfortable and contemplative places. She believes in the potential of introspection and collective wisdom in public space to improve our communities and help us lead better lives." ${ }^{45}$

\footnotetext{
${ }^{44}$ Candy Chang, Before I Die, 2011, New Orleans, http:// candychang.com/before-i-die-in-nola, accessed May 15, 2014.

${ }^{45}$ Candy Chang, TED Speaker, TED: Ideas worth spreading, http://www.ted.com/speakers/candy_chang, accessed May $15,2014$.
} 

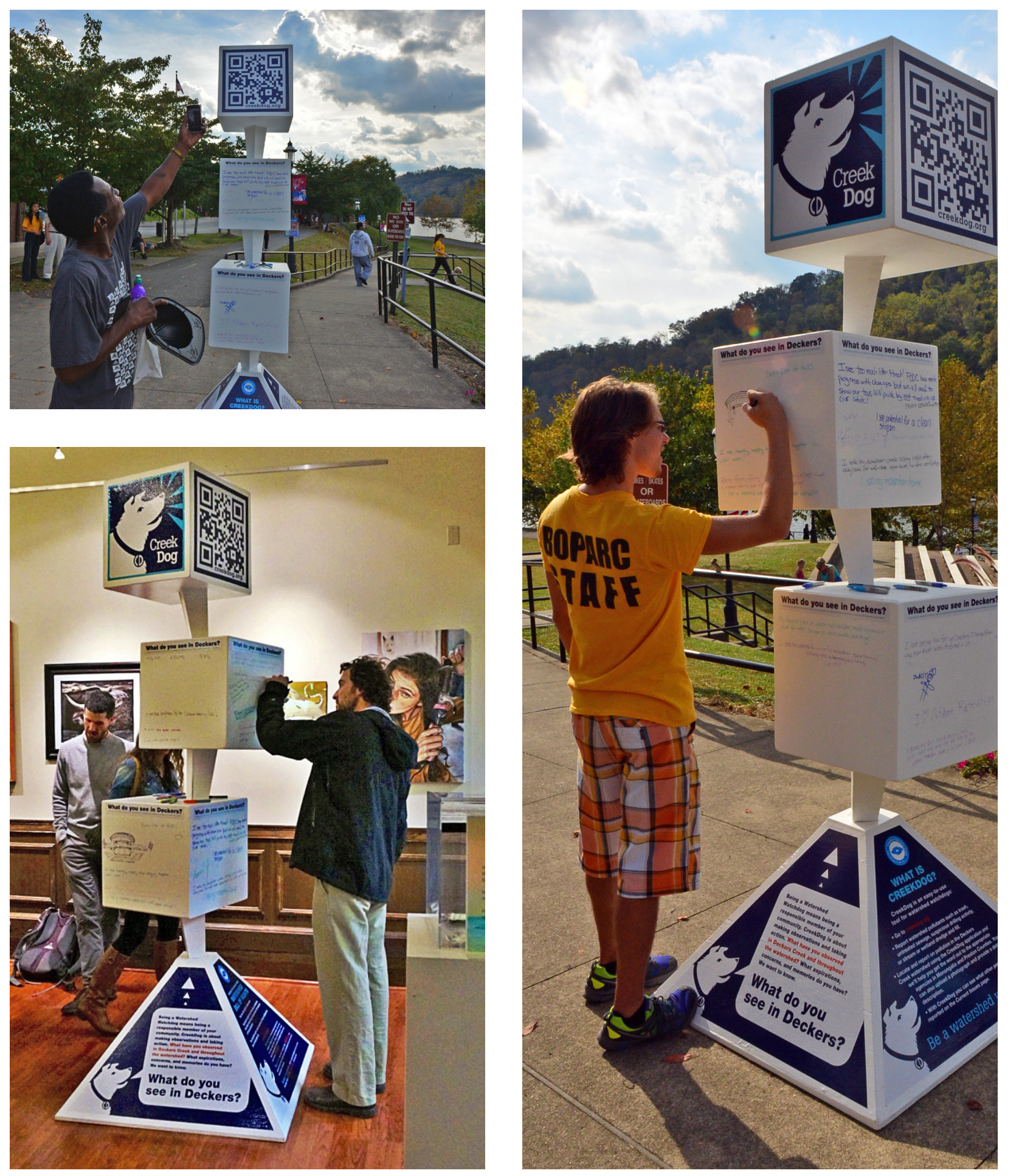

Figure 5.14: CreekDog display at the Morgantown West Virginia Water Festival at Hazel Ruby McQuain Park and at the 2103 FODC Holiday Social at Arts Monongahela 


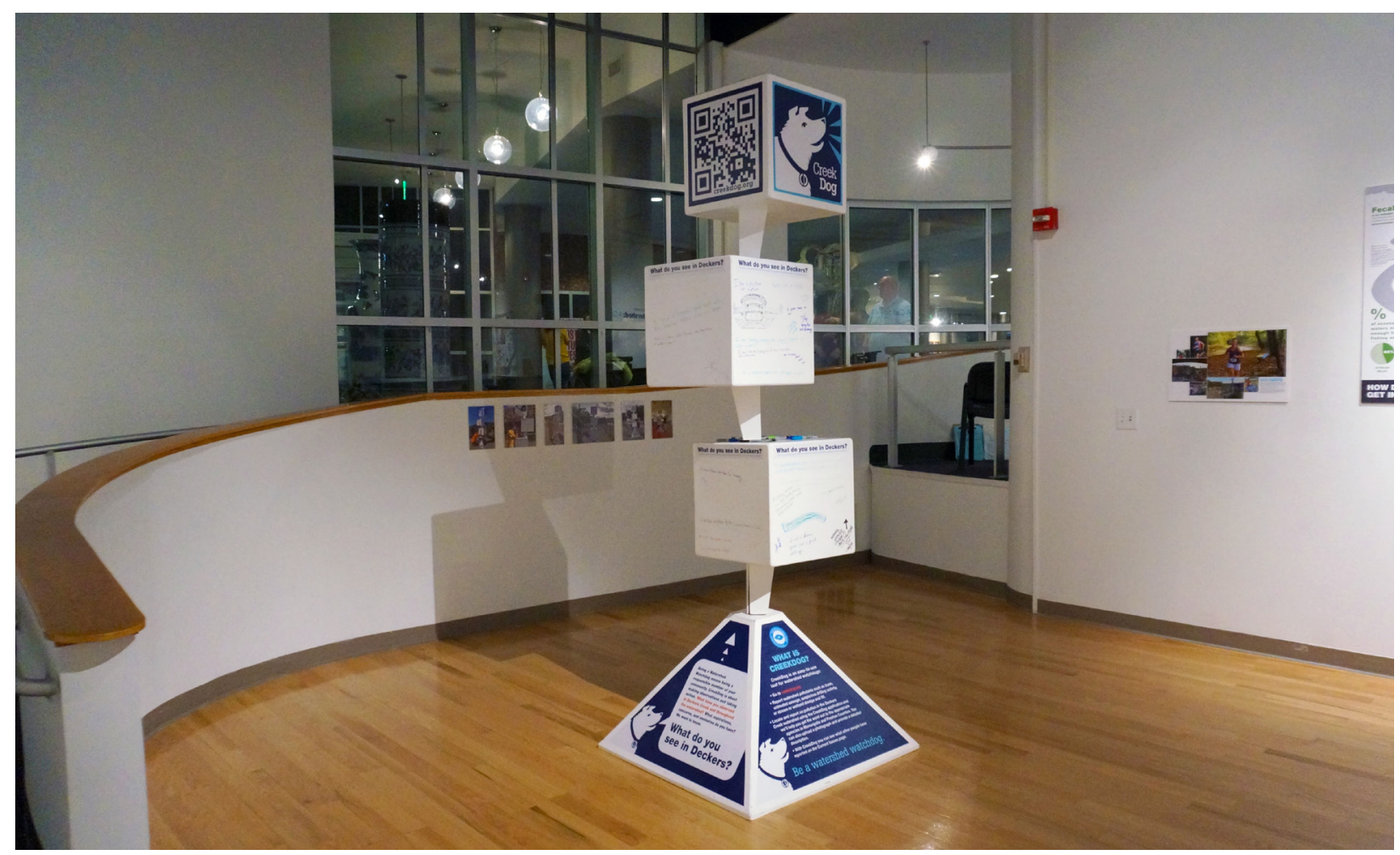

Figure 5.15: CreekDog display at the MFA thesis exhibition at the Laura Mesaros Gallery, WVU Creative Arts Center

"So this neglected space became a constructive one, and people's hopes and dreams made me laugh out loud, tear up, and they consoled me during my own tough times. It's about knowing you're not alone. It's about understanding our neighbors in new and enlightening ways. It's about making space for reflection and contemplation, and remembering what really matters most to us as we grow and change." - Candy Chang ${ }^{46}$

In these voices (fig.5.16-17) I was able to see my own hopes, fears, and concerns about the watershed reflected back at me. I was able to laugh and make new discoveries. I was able to see my own relationship to the watershed, and my relationship to my community. This gives the audience a sense of empowerment. They know they are not alone in their aspirations or their efforts. This display helps to build a greater sense of community.

For the brand, CreekDog, this piece helps highlight the collaborative efforts between the community and the grassroots necessary to tackle the complex pollution problems within the watershed. By realizing their personal connection to the watershed, they begin to see themselves as "watershed watchdogs," and therefore become part of the branding of CreekDog. The brand is strengthened by their voices and their shared collaboration.

${ }^{46}$ Candy Chang, "Candy Chang: Before I die I want to..." (video of lecture, TEDGlobal 2012, Edinburgh, Scotland, Filmed July 2012), http://www.ted.com/talks/candy_chang_ before i die i want to/transcript, 4:04 minutes, accessed May 15, 2014. 


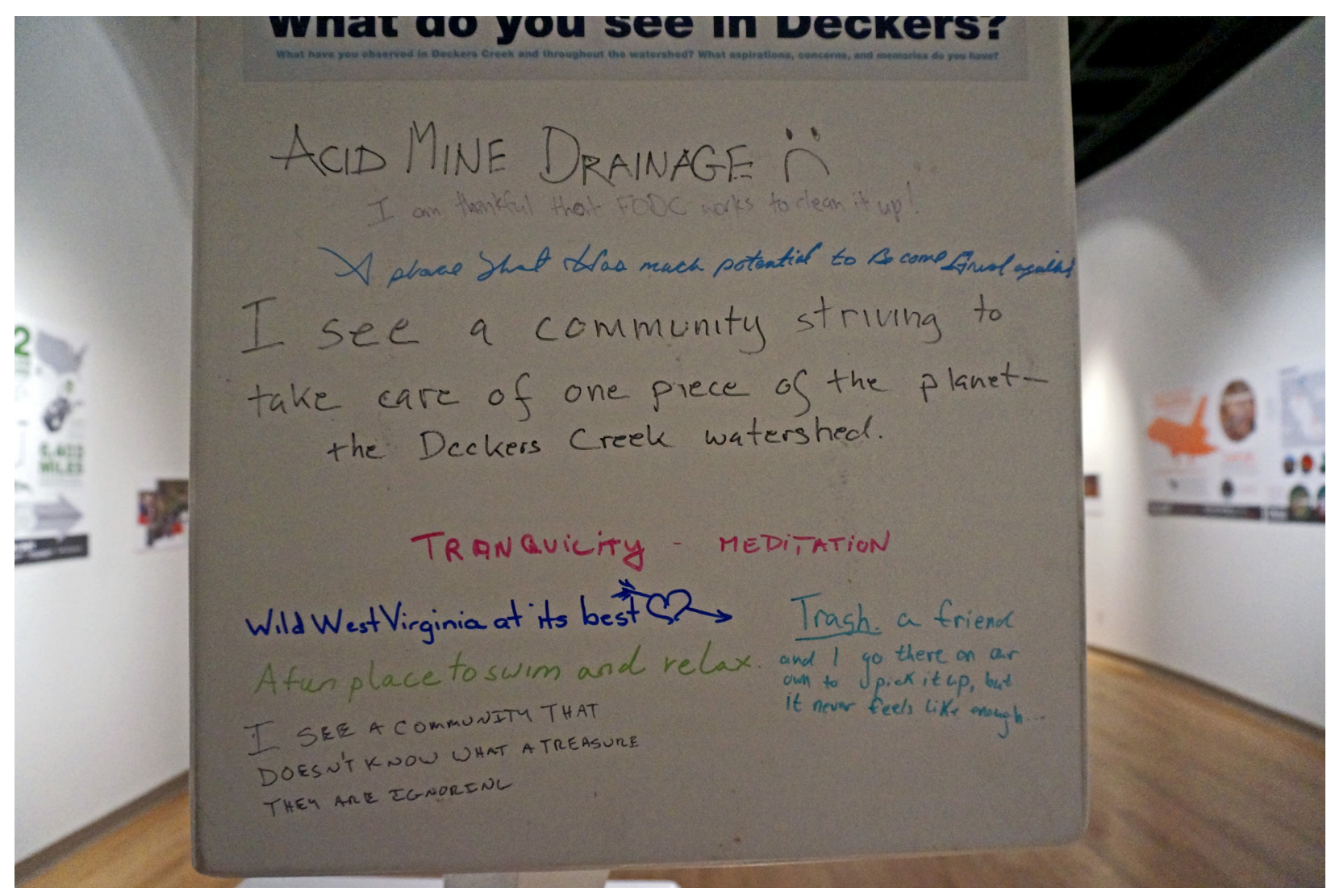

Figure 5.16: CreekDog display, MFA thesis exhibition, detail of visitor's contributions

Knowing their motivations, fears, memories, recreational activities, and aspirations, helps us to build marketing strategies in the future. If CreekDog is to become a voice of the people, then the brand must carry this voice as well. These voices help to create a shared narrative around Deckers Creek. Some of the experiences shared on this display were as follows:

"(I saw) a belted kingfisher at the Outdoor Learning Park!"

"I see potential for GREAT things to happen but it begins with people like US!"

"I see a community striving to take care of one piece of the planet - the Deckers Creek Watershed."

"I see a community that doesn't know what a treasure they are ignoring."
"Where my ex threw my engagement ring."

"I've seen a black bear beside Decker's near Sabraton!"

"I see the past (mining) and future (conservation) meeting."

"The best waterfalls that I can bike to."

"I see healthy happy kids playing together in clean water."

"We need to stop them from dumping wastewater in the well near Masontown. A clean place to set + see nature + shade + relax + talk..."

This last statement refers to a potential wastewater injection well that was being proposed at the time of this exhibition (fig.5.17). The well would have stored fracking wastewater fluid from regional horizontal gas well operations. This proposed injection well was being pursued by the Energy Corporation 
What do you see in Peckers?

I've seen a blast bear beside Dater's near Sabratabon!

We needithem from dumping wastewater in the well near Mason town.

a Clear place to set a see Nature a Shade + Relax, talk, watch Nature, Fish orreluase. In God's Nome I Pray the!

BEAUTY, BioToPE

The best waterfalls that I can bike to.

Figure 5.17: CreekDog display, MFA thesis exhibition, detail of visitor's contributions displaying anxiety in relation to ECA's proposed fracking wastewater injection well in Masontown, WV.

46 
of America (ECA) and the wellhead would have sat approximately 500 feet from the edge of the creek and the rail trail. This raised public concern that this well could potentially compromise the health of Deckers Creek by risk of pollution. An effort lead by Friends of Deckers Creek, drew a wide community opposition to this proposal. Friends of Deckers Creek helped to form a broad-based community group, No Injection Well that ultimately raised enough public support to discourage ECA's proposed well. ${ }^{47}$ The No Injection Well group educated the citizens in the area by holding public meetings, talking to stakeholders, canvasing neighborhoods with petitions, collecting signatures, and creating a website - noinjectionwell.org. Several members from this group attended the opening reception for the exhibition and used this as an opportunity to collect signatures and spread the word about the potential risks involved with the proposed well.

On April 18, 2014, ECA announced that they were no longer pursuing plans to develop the underground injection well. ${ }^{48}$
47 "Home" No Injection Well, http://noinjectionwell.org, (accessed May 11, 2014).

48 David Beard, "Energy Corp. scraps Masontown well plans, The Dominion Post, April 18, 2014, accessed April 19, 2014. http://thedpost.com/Energy-Corp--scraps-Ma--sontown 


\section{Information Graphics and Data Visualization}

A bulk of the educational content featured at the exhibition took on the form of information graphics and data visualization. Three information graphics were created to educate the public on the following pollution issues:

1. Untreated Sewage (fig.5.18);

2. Acid Mine Drainage, specifically the Richard Mine (fig.5.20);

3. Illegal Trash and Litter (fig.5.22).

A data visualization was also created in the form of a watershed map. (fig.5.23) This visualization showed the effects of pollution through monitoring data collected at several different sites throughout the watershed.

People mistakenly think that design is a way to simplify and streamline information. The true intent of design should not be to disguise what is complex but instead should be a way of managing difficult information. Design should indeed show information in ways that makes its message clear, but for subjects that are complex, it should do so in ways that show that intricacy.

Data visualization pioneer, Edward Tufte explains in his book, The Visual Display of Quantitative Information:

What is to be sought in designs for the display of information is the clear portrayal of complexity. Not the complication of the simple; rather the task of the designer is to give visual access to the subtle and the difficult that is, the revelation of the complex. ${ }^{49}$
The intent of these pieces was to highlight these issues in ways that made the information comparable and understandable for a diverse audience. For these information graphics, educating the public is only part of the solution. To create action it is important to highlight ways that the audience can take action on these issues. Each of the three information graphics has a section titled, "What can you do?" This provides actionable items so that everyone leaves with some sense of what they can do to contribute.

These graphics combine information, mostly from public agencies such as the Environmental Protection Agency (EPA), in a visual way that shows the breadth of the issue. These graphics are also color coded, green for sewage, orange for acid mine drainage, and cyan for trash. Each one uses simple vector graphics and silhouettes along with facts, figures, and percentages to tell their story. (fig.5.19) Because of the multitude of information displayed, the treatment of the illustrations is stripped to the essentials, making them immediate and recognizable. Each graphic begins with a key element that draws the focus of the viewer. These key elements are unexpected for the topic at hand, but are an element of surprise and they present some sort of comparative information. This provides a way to visualize numbers and data with forms that invoke more empathy from sources

\footnotetext{
${ }^{49}$ Edward R. Tufte, The Visual Display of Quantitative Information, Epilogue: Designs for the Display of Information, (Cheshire, Connecticut: Graphics Press, 2001), 191.
} 


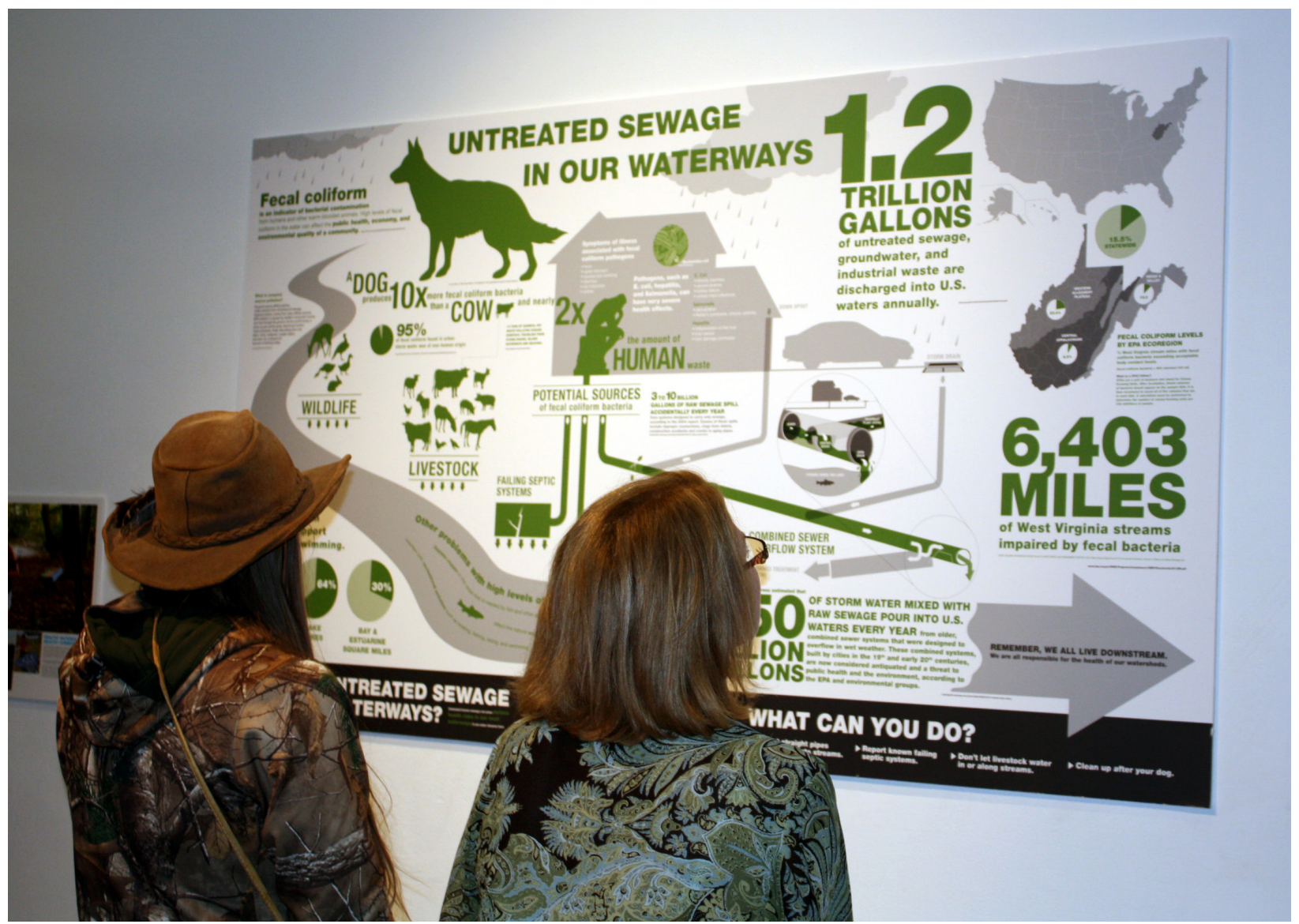

Figure 5.18: Untreated Sewage in Our Waterways

that are usually thought as having positive attributes. Here, we embed themes such as art, music, space travel, and animals to help explain pollution issues.

These innovative, informative displays bridge disciplinary knowledge in ways that create a unique experience and a mnemonic device. This experience challenges the audience's perceptions by creating familiarity within the understanding of the topic, and calls them to act on this new change in reality.

\section{Untreated Sewage in Our Waterways}

This display answers the question, "How does untreated sewage get in our waterways?"

(fig.5.18) This is a difficult problem to present to the audience. The biggest challenge is to talk about human and animal excrement in a way that the audience will want to pay attention. The graphic begins by defining fecal coliform bacteria. The key element that draws your eye first is a silhouette of a dog. It states that a dog produces ten times the amount of fecal coliform bacteria that a cow produces 


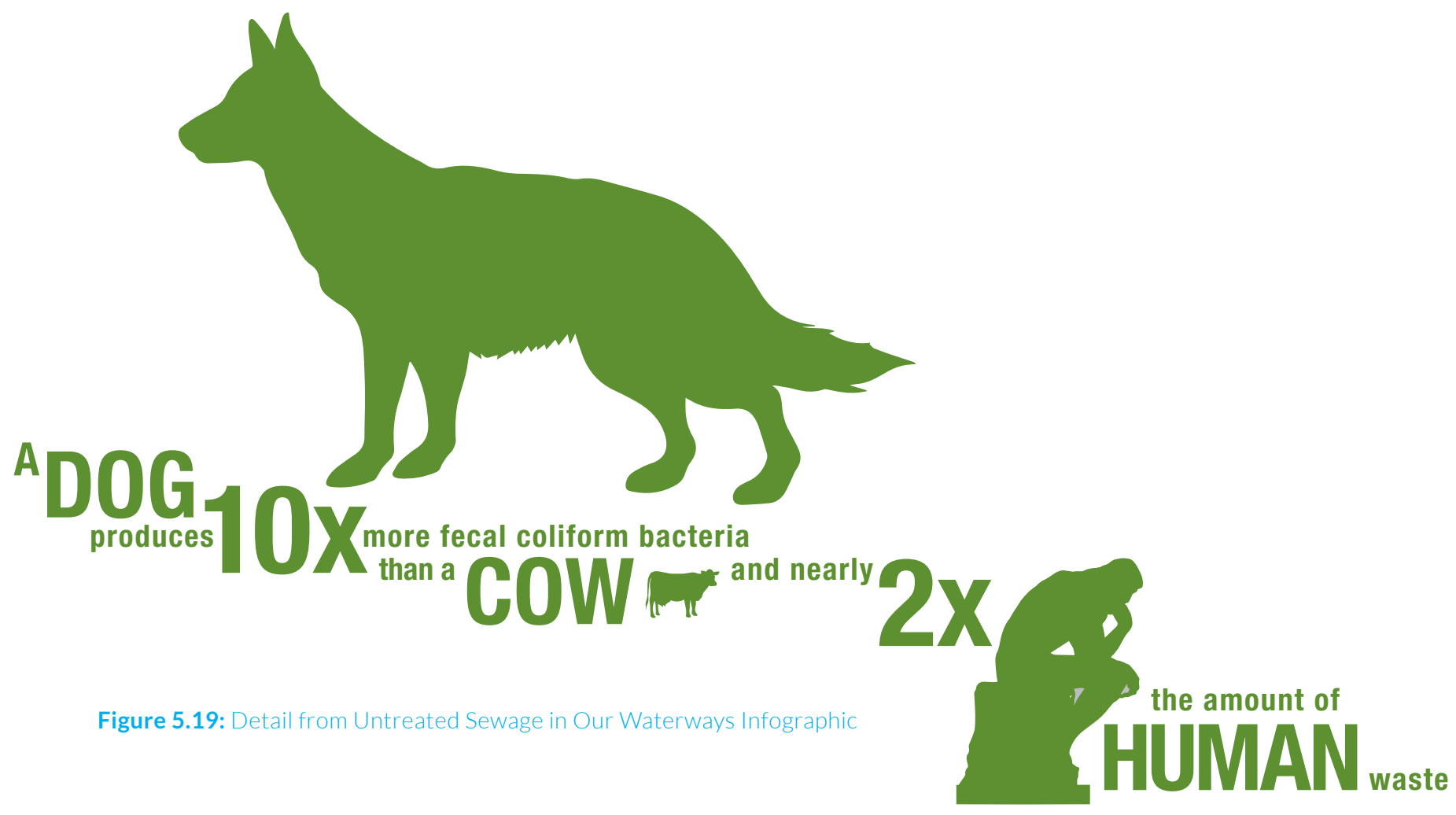

and two times that of a human. ${ }^{49}$ To emphasize this comparison, the size of the dog is ten times the size of the cow and two times the size of the human (fig.5.19). The seated human silhouette references Auguste Rodin's iconic sculpture of The Thinker. ${ }^{50}$ Looking as if he is seated upon a toilet, this humorous reference is used intentionally because the location is specific to the Creative Arts Center, gallery space, and is intent on resonating with the arts community.

The other challenge with talking about this type of pollution is its complexity. It enters our water system through a variety of sources that are not always easily identified. It was important to help the audience understand the role that storm water plays in this system and how it carries fecal coliform bacteria from its sources to the stream. Non-point source pollution ${ }^{51}$ stems from rain, snowmelt, or water moving across the watershed where it is eventually deposited in our waterways. Because this type of pollution is dispersed from multiple sources, it is difficult to identify the causes or solution. As the graphic explains, these sources could stem from livestock watering along streams to failed septic systems. It also explains point sources of untreated sewage such as controlled sewage overflow systems and illegal straight pipes that carry sewage directly into streams. Public agencies were also consulted for this graphic. For instance, Stormwater specialists at Morgantown Utility Board (MUB) helped

\footnotetext{
49 USEPA:Pollution Prevention/Good Housekeeping for Municipal Operations, National Menu of Best Management Practices Fact Sheets, University of Wisconsin, http:// www3.uwm.edu/Dept/shwec/publications/cabinet/other/ EPAMunicipalSWP2BMPs.pdf, accessed May 15, 2014.

50 Auguste Rodin, The Thinker, 1903, Musée Rodin, Paris, France.

51 "What is Nonpoint Source Pollution?," Water: Polluted Runoff, United States Environmental Protection Agency, http://water.epa.gov/polwaste/nps/whatis.cfm, accessed May 15, 2014.
} 


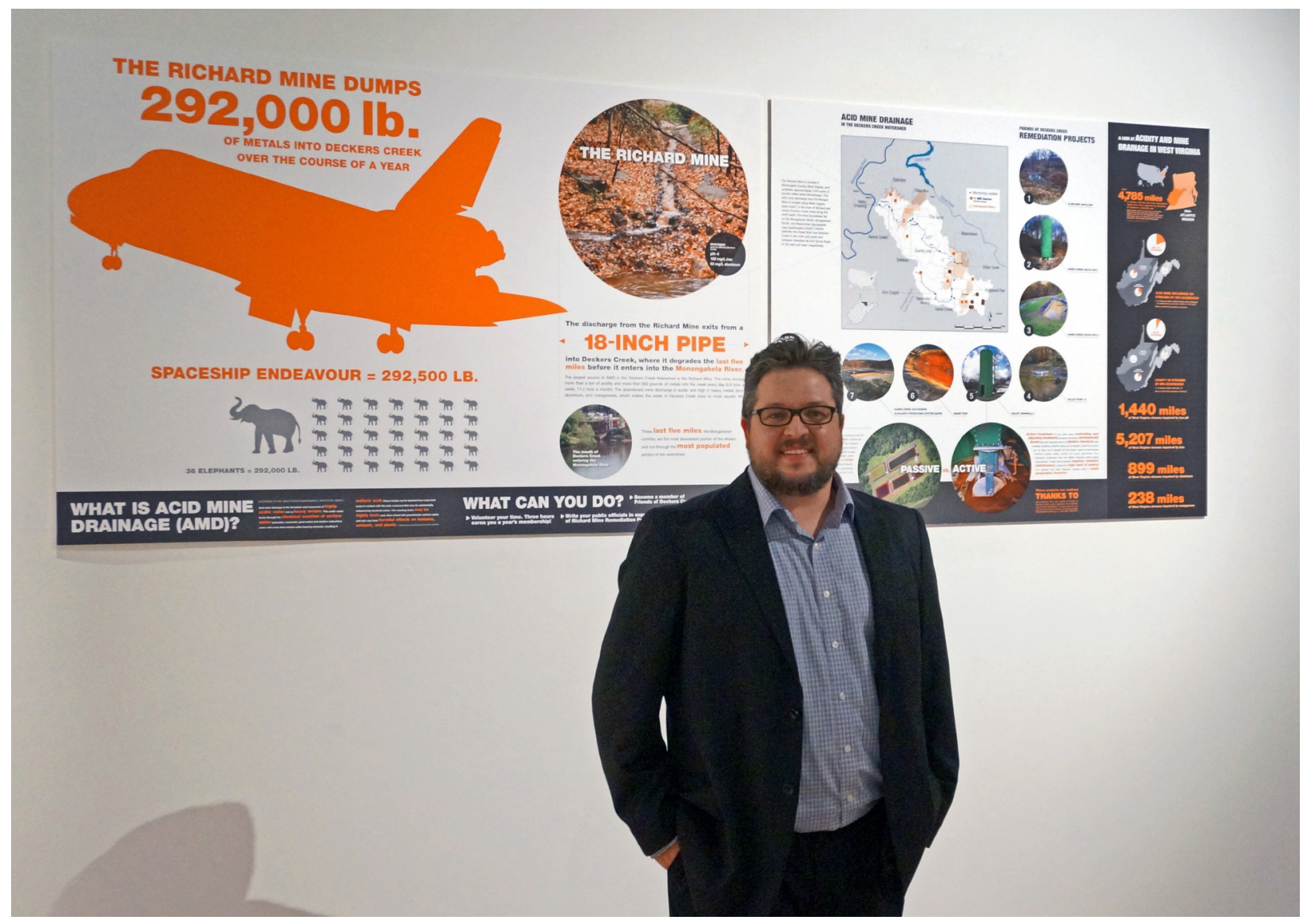

Figure 5.20: Information graphic: Acid Mine Drainage, the Richard Mine, and FODC Remediation Projects

to provide information on identifying illegal straight pipes. ${ }^{52}$ This information provides the audience with the knowledge of what to look for and helps them to identify potential sources of untreated sewage. In addition to providing examples of sources this graphic also provides information about sewage issues across the state of West Virginia and the nation. This helps to provide a context that these pollution issues are not isolated to our watershed but they plague communities across the nation.

\section{Call to action items:}

- Report straight pipes discharging into streams.

- Report known failing septic systems.

- Don't let livestock water in or along streams.

- Clean up after your dog.

\section{Acid Mine Drainage, the Richard Mine, and FODC Remediation Projects}

(fig.5.20)

This graphic helps to explain the biggest problem plaguing the watershed - acid mine drainage, also known as AMD. According to the United States Environmental Protection Agency, acid mine drainage is the formation and movement of highly acidic water rich in heavy metals. This acidic water forms through the chemical reaction of surface water (rainwater, snowmelt, pond water) and shallow subsurface water with rocks that contain sulfur-bearing

\footnotetext{
52 Kenneth Hacker, Morgantown Utility Board, e-mail message to author, Monday, December 2, 2013.
} 


\section{THE RICHARD MINE DUMPS
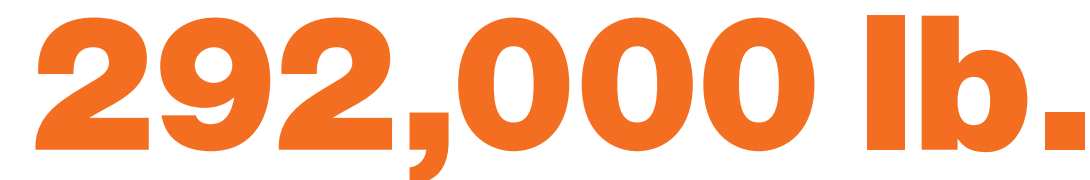

OF METALS INTO DECKERS CREEK

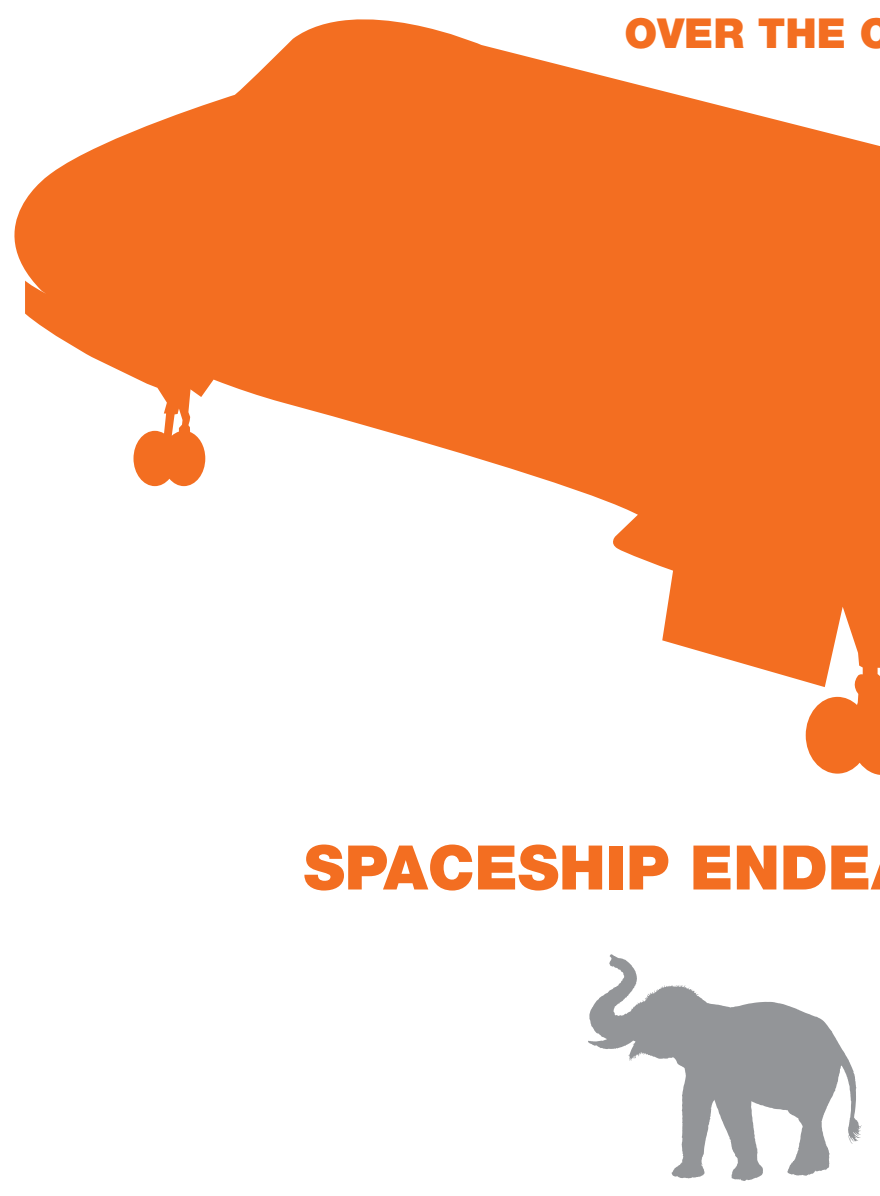

COURSE OF A YEAR

36 ELEPHANTS = 292,000 LB.

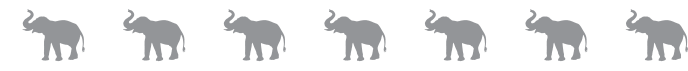

3.

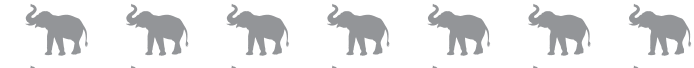

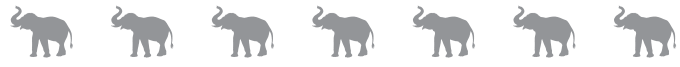

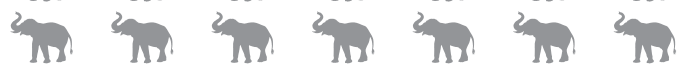

Figure 5.21: Acid Mine Drainage, the Richard Mine, and FODC Remediation Projects detail 
minerals, resulting in sulfuric acid. Heavy metals can be leached from rocks that come in contact with the acid, a process that may be substantially enhanced by bacterial action. The resulting fluids may be highly toxic and, when mixed with groundwater, surface water, and soil, may have harmful effects on humans, animals, and plants. ${ }^{53}$

The largest source of AMD in the watershed is the Richard Mine.(fig.5.21) The mine dumps more than a ton of acidity and more than 800 pounds of metals into the creek every day (2.8 tons a week, 11.2 tons a month). ${ }^{54}$ The abandoned mine discharge is acidic and high in heavy metals (iron, aluminum, and manganese), which makes the water in Deckers Creek toxic to most aquatic life. The Richard Mine decimates the last five miles of the stream, the Morgantown Corridor. ${ }^{55}$ These last five miles run through the most populated portion of the stream.

The key feature for this information graphic is a large orange silhouette of a spaceship (fig.5.21). This unusual feature helps to explain the amount of metals that are dumped by the Richard over the course of a year. Eight hundred pounds of metals every day or the sum total of those metals per year, 292,000 pounds, is extremely hard to imagine. Without some frame of reference these numbers are virtually meaningless to the audience. But when we use this image, the Spaceship Endeavor, ${ }^{56}$ to explain that this is the amount of metals discharged by the Richard Mine over the course of the year, it becomes comparable and understandable to the audience. The realization of the immensity of this pollution is compounded when the spaceship is compared to the 18-inch circle to its right. This circle represents the pipe from which the discharge exits. This comparative information helps to narrate the severity of the pollution issue. The circle also contains a photograph showing the Richard discharge entering the stream.

In addition to explaining the severity of the problem, it is equally important to show it in context of the rest of the watershed. Tangent lines are drawn from the 18-inch circle to the location of the AMD source on a map of the entire watershed. This map shows the footprint of all of the underground mines and marks all of the 17 AMD sources in the watershed. It also shows the flow of Deckers Creek and all of its major tributaries as they converge. Seven Friends of Deckers Creek remediation projects are also referenced on the map. Each of these sites is identified and has a corresponding photograph. It was important to highlight these remediation projects to show the investment that agency, private landowners, and Friends of Deckers Creek have made to the health of the watershed. This helps to highlight the extent of work the FODC does for their community. Many people are unaware of these remediation efforts and how extremely integral they are to the mission. Many of

\footnotetext{
53 Abandoned Mine Drainage, Water: Polluted Runoff, United States Environmental Protection Agency, http://water.epa.gov/polwaste/nps/acid_mine.cfm\#info, accesssed May 15, 2014.

${ }^{54}$ Acid Mine Drainage, Friends of Deckers Creek, Projects, http://www.deckerscreek.org/about/projects/acid-minedrainage, accessed May 15, 2014.

55 Alyse Schrecongost and Evan Hansen, "Local Economic Benefits of Restoring Deckers Creek: A Preliminary Analysis," Friends of Deckers Creek, August 2005,

Publications, http://www.deckerscreek.org/images/stories/ pdf/DeckersEconomicAnalysis.pdf, accessed May 15, 2014.

56 Tundra Endeavour, http://www.toyota.com/ tundraendeavour, accessed May 15, 2014.
} 
these efforts exist on private land and are not readily accessible or visible to the greater community. This graphic begins to create a new realization for the audience. Doing so helps to support the case for Richard Mine remediation efforts.

In addition, we help to explain the methods used to remediate the stream and we also look at acid mine drainage across the Mid-Atlantic Region and within the state of West Virginia. As with the Untreated Sewage graphic, this helps to provide context for our local example within the state and the region.

\section{Call to action items:}

- Write your public officials in support of Richard Mine Remediation Project.

- Become a member of Friends of Deckers Creek.

- Go to: deckerscreek.org or email: info@deckerscreek.org.

- Volunteer your time. Three hours earns you a year's membership!

Since this exhibition, these graphics have continued to be used to educate the public. They can be seen on display at the FODC office and are taken to public outreach events. On June 17, 2014, Friends of Deckers Creek hosted a community meeting to promote the remediation project for the Richard Mine. These infographics were used to help educate the public at this meeting. Two local media outlets, the Dominion Post, and WBOY covered the meetings. ${ }^{57}$ Both of these news sources referenced information provided by this infographics. WBOY quoted in the second paragraph of their story, "The Richard Mine dumps 292,000 Ibs. of metals into Deckers Creek every year. That's the equivalent in weight to the Space Shuttle Endeavor, or 35 elephants." ${ }^{8}$ WBOY and the Dominion Post featured the graphics through videos and photographs of the event. ${ }^{59}$

This demonstrates the effectiveness of the design strategy of these pieces. The message not only provided the public and media with knowledge about these issues but made the information memorable for the audience. By doing so, they provide a tool which creates the opportunity for continued narrative. This form of narrative becomes easier to disseminate to a wider public audience outside of the organization.

\footnotetext{
57 "Friends of Deckers Creek Hosts Community Meeting to Promote Richard Mine Project," News and Events, Friends of Deckers Creek, accessed June 21, 2014, http://deckerscreek. org/.

${ }^{58}$ Lauren Talotta, "Friends of Deckers Creek Proposes Water Treatment Plant to Prevent Acid Mine Drainage," WBOY 12 News, June 18, 2014, accessed June 21, 2014, http://www.wboy.com/story/25804257/friends-of-deckerscreek-proposes-water-treatment-plant-to-prevent-acidmine-drainage.

${ }^{59}$ Eric Tomlinson, "Richard Mine Drainage Public Meeting 6-17-2014," (video) The Dominion Post, June 17, 2014, accessed June 21, 2014, http://www.youtube.com/ watch? $\vee=\mid Y 4 y \vee h j S C U U$.
} 


\section{Trash and Litter}

Friends of Deckers Creek was founded by a grassroots collaboration of concerned citizens and recreation enthusiasts. One of the most basic and public ways they have taken action to improve the watershed is through trash clean-up events throughout the year. In August 2013, Friends of Deckers Creek was awarded a Lifetime Achievement Award by West Virginia Adopt-A-Highway for their efforts. ${ }^{60}$ The key object in this display is a silhouette of Steinway Grand Piano (fig.5.22). This representation calls attention to the amount of trash that FODC has cleaned up since 1996. Sixty-six Steinway Grand Pianos represent the 66,000+ pounds of trash that have been cleaned up. This is also equivalent to an average American's trash production for 40 years. While at first the representation of the Steinway seems arbitrary, it like Rodin's Thinker in the Untreated Sewage display uses the context of the gallery space within the Creative Arts Center for the fact that the West Virginia University College of Creative Arts is pursuing a spot on the list of All-Steinway Schools. ${ }^{61}$

The bulk of the display illustrates the impact of litter across the nation. It attempts to dispel myths of litter for materials like tobacco products. ${ }^{62}$ This graphic calls attention to the top ten most littered items in the United States. ${ }^{63}$ Number one and number ten on list are tobacco related products because people do not view them as litter. Many misconceptions stem from people believing that these objects decompose. Their size also contributes to their proliferation. People do not see these small objects as a problem, but collectively they can have an impact because one cigarette butt can poison two gallons of water. ${ }^{64}$ Decomposition rates are listed along with these top ten items to show how long they would last if left in the environment.

To provide a broad view of the issues this display highlights economic and social impacts in regards to trash and litter.

\section{Call to action items:}

- Report issues to your local litter officer.

- Organize a trash cleanup through Friends of Deckers Creek.

- Secure garbage and recycling for curbside pickup in cans with lids.

- Watch for illegal trash dumping or properties that appear to be unsafe or unsanitary.

- Take action! Use creekdog.org to report illegal trash issues.

- Properly dispose of cigarette butts.

- Adopt a highway!
${ }^{60}$ Friends of Deckers Creek, "FODC honored for AdoptA-Highway work," The Dominion Post, The DPost Blogs, September 10, 2013, accessed May 15, 2014.

${ }^{61}$ Charlene Lattea, "First new Steinway piano arrives at WVU," WVUToday, West Virginia University, Creative Arts Center, December 15th, 2011, http://wvutoday.wvu. edu/n/2011/12/15/first-new-steinway-piano-arrives-atwvu-creative-arts-center\#sthash.9hpaovS1.dpuf College of Creative Arts, accessed May 15, 2014

${ }^{62}$ Action Research, "Littering Behavior in America: Results of a National Study," January, 2009, Prepared for Keep America Beautiful, http://www.kab.org/site/DocServer/ KAB_Report_Final_2.pdf?doclD $=4581$, accessed May 15, 2014.

63 "Tracking Trash: 25 Years of Action for the Ocean," 2011 Marine Debris Report, Ocean Conservancy, http://act. oceanconservancy.org/pdf/Marine_Debris_2011_Report_ OC.pdf, accessed May 15, 2014.

${ }^{64}$ Kathleen Register, "Cigarette Butts as Litter - Toxic as Well as Ugly?", Underwater Naturalist, Bulletin of the American Littoral Society, Volume 25, Number 2, August 2000, http://www.cigarettelitter.org/index. asp?pagename=un, accessed May 15, 2014. 


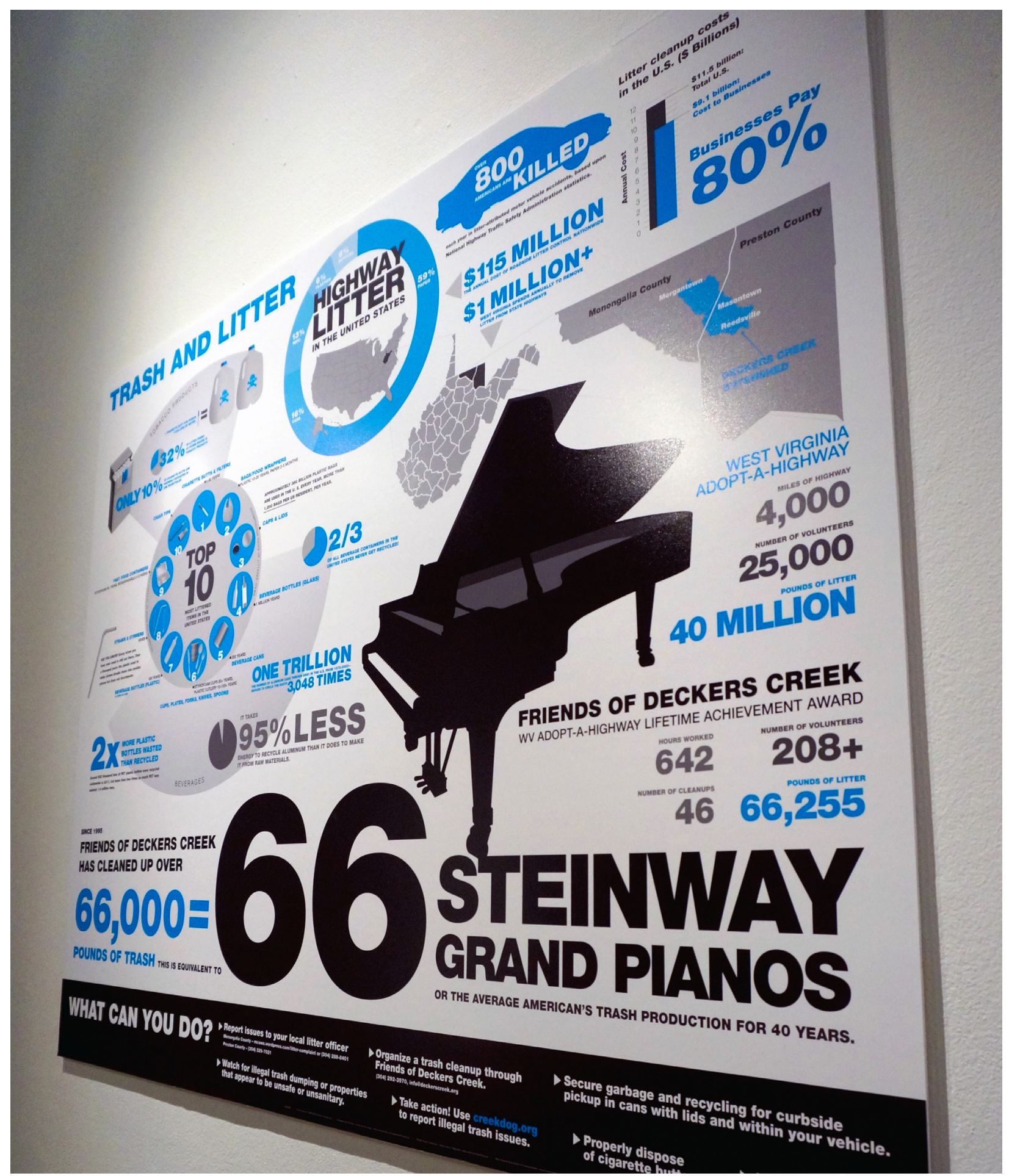

Figure 5.22: Trash and Litter information graphic 


\section{Data Visualization Map}

A large vinyl floor graphic situated in the middle of the floor of the gallery space depicted a map detailing the Deckers Creek Watershed (fig.5.24). The map is oriented north and helped bring a sense of place to the gallery. It provided an educational experience and points of discussion for the audience.

This data visualization titled, "Pollution in the Deckers Creek Watershed," highlights data from 13 monitoring locations throughout the watershed (fig.5.23). This maps shows the watershed in relation to water features such as the Monongahela River, Cheat River, and Cheat Lake. ${ }^{65}$ It provides base level information such as the watershed boundary, directional flow, and county demarcations, and town/city locations.

It also provides a summary of data collected through Friends of Deckers Creek's Clean Creek Program. Through the Clean Creek Program teams of citizen scientists, FODC staff, and professional scientists monitor, collect, and assess these locations throughout the stream. ${ }^{66}$

Water quality parameters including $\mathrm{pH}$, temperature, conductivity, and dissolved oxygen are collected in the field using handheld probes. Flow is also measured using a flow meter. Water samples are taken to West Virginia University (WVU) National Research Center for Coal and Energy Analytical Laboratory for further analysis, including the presence of fecal coliform bacteria, and various metals.

Fish communities are assessed annually in early fall using backpack electrofishers in collaboration with WVU Wildlife and Fisheries
Department. The backpack electrofisher passes a small electrical current through the water and stuns fish so that they can easily be collected with nets. The fish are then subdued, identified, weighed, measured, and returned unharmed to their point of capture.

Benthic macroinvertebrate communities are sampled in the spring using square kick nets. Benthic macroinvertebrates are creatures that live in sediments at the bottom of a stream and are good indicators of water quality. Samples are taken back to the FODC laboratory and species are identified and tallied. FODC integrates information about the different types of organisms and their numbers into scores that reflect water quality using the WV Department of Environmental Protection West Virginia Stream Condition Index (WVSCI).

\footnotetext{
${ }^{65}$ M.J. Christ, The State of the Creek, 2005: The Clean Creek Program Annual Report, "State of the Creek, 2005," April 2006, page 36, figure 40, Friends of Deckers Creek, Dellslow, West Virginia, http://www.deckerscreek.org/ images/stories/pdf/Friends\%20of\%20Deckers\%20 Creek\%20State\%20of\%20the\%20Creek\%202005.pdf, accessed May 15, 2014.

66 "Clean Creek Program," Projects, Friends of Deckers Creek, http://www.deckerscreek.org/about/projects/cleancreek-program-sponsors, accessed May 15, 2014.
} 


\section{Pollution in the Deckers Creek Watershed}

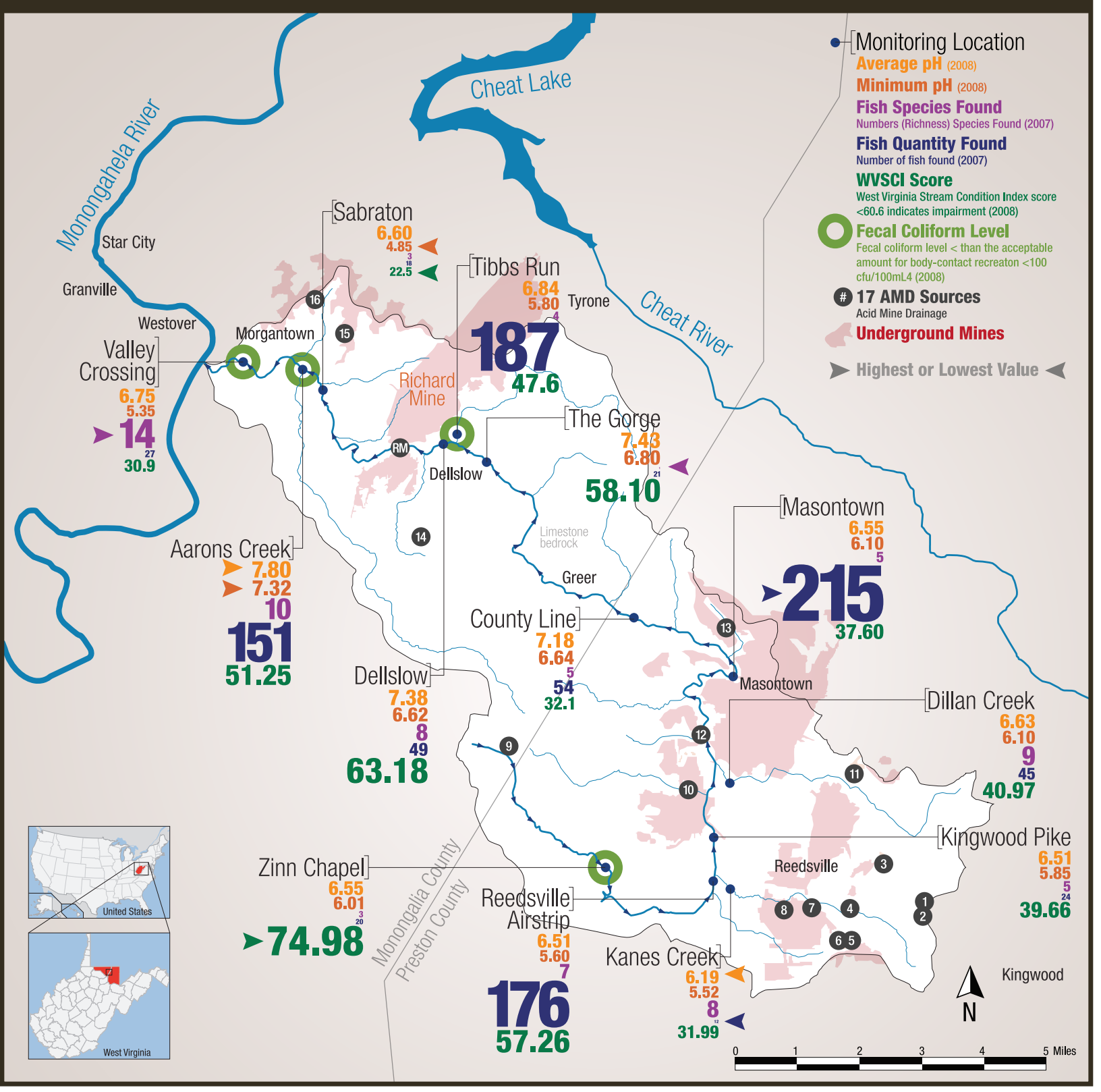

Figure 5.23: Floor map displaying comparable data of pollution in the Deckers Creek Watershed. 
This map combines several data sets into one holistic view of the watershed. On the basemap the footprint of all of the deep mines and the location of 17-high priority AMD sources in the watershed are indicated. ${ }^{67}$ Each of the 13 monitoring locations show numbers for average $\mathrm{pH}$, minimum $\mathrm{pH}$, fish species diversity, fish quantity, West Virginia Stream Condition Index score (WVSCI), ${ }^{68}$ and levels of fecal coliform bacteria that are greater than the acceptable amount for body-contact recreation are highlighted. ${ }^{69}$ Each category is color coded and listed in the same order at each location. With the exception of fecal coliform bacteria, numbers for each of these categories are shown in relation to each other proportionally by a change in size. Large amounts for each category appear bigger. The highest and lowest values across these locations are highlighted with an arrow. The locations with a fecal coliform level higher than the acceptable amount are shown as a concentric green circle.

My approach to this map relies heavily on the influence of Tufte and employs the use of small multiples:

Small multiples are economical: once viewers understand the design of one slice (data set), they have immediate access to the data in all the other slices. Thus as the eye moves from one slice to the next, the constancy of the design allows the viewer to focus on the changes in the data rather than on changes in graphical design. ${ }^{70}$

This system allows for all of this data to be studied within monitoring locations and across locations. This provides the viewer with an opportunity to compare data within a location to create narratives. For instance, a location with a low WVSCI score indicating poor water quality, with a low fish diversity number, and a high fish quantity number could conclude that the fish found in this area are pollution-tolerant species. An example of this very occurrence is illustrated at the Masontown location on the map, where creek chubs and yellow bullhead are found. Also on the map, minimum $\mathrm{pH}$ levels decrease downstream from the Richard Mine, along with WVSCI scores and fish numbers. Discrepancies in the data also create their own narratives. The final monitoring set, Valley Crossing, is located at the end of Deckers Creek and before it empties into the Monongahela River. This location also falls downstream of the Richard mine, has a low number of fish, but has the highest number in terms of fish diversity. One can conclude that this is because of the proximity to the Monongahela River and occurs because of fish moving upstream into Deckers Creek.

\footnotetext{
${ }^{67}$ M.J. Christ, The State of the Creek, 2005: The Clean Creek Program Annual Report, "State of the Creek, 2005," April 2006, page 35, figure 39, Friends of Deckers Creek, Dellslow, West Virginia, http://www.deckerscreek.org/ images/stories/pdf/Friends\%20of\%20Deckers\%20 Creek\%20State\%20of\%20the\%20Creek\%202005.pdf, accessed May 15, 2014.

68 "West Virginia Stream Condition Index (WVSCI)," West Virginia Department of Environmental Protection, Benthic Macroinvertebrate sampling and data, State of West Virginia 2014, http://www.dep.wv.gov/wwe/watershed/ bio_fish/pages/bio_fish.aspx, accessed May 15, 2014.

69 "2010 West Virginia Integrated Water Quality Monitoring and Assessment Report," West Virginia Department of Environmental Protection Division of Water and Waste Management, http://www.dep.wv.gov/WWE/Programs/ nonptsource/WBP/Documents/2010IR.pdf, accessed May 15, 2014, 13.

70 Edward R. Tufte, The Visual Display of Quantitative Information, Epilogue: Designs for the Display of Information, (Cheshire, Connecticut: Graphics Press, 2001), chap. 1 Graphical Excellence, 42.
} 
While narratives within the graphic are useful, narratives within the context of the gallery space are even more useful. This was especially true for the crowd at the opening reception. This piece became an impromptu way for knowledgeable citizens, FODC members, and other experts, to educate others about the watershed. These visitors traded stories about pollution threats, remediation efforts, landmarks, and recreational opportunities in the watershed. (Fig.5.24) In many ways became a source of entertainment and way to create an expanded narrative. The stories shared by the community become a deeper form of engagement. Facts are shared along with the emotion and excitement about the place. It provides a human connection, empathy, and a shared sense of

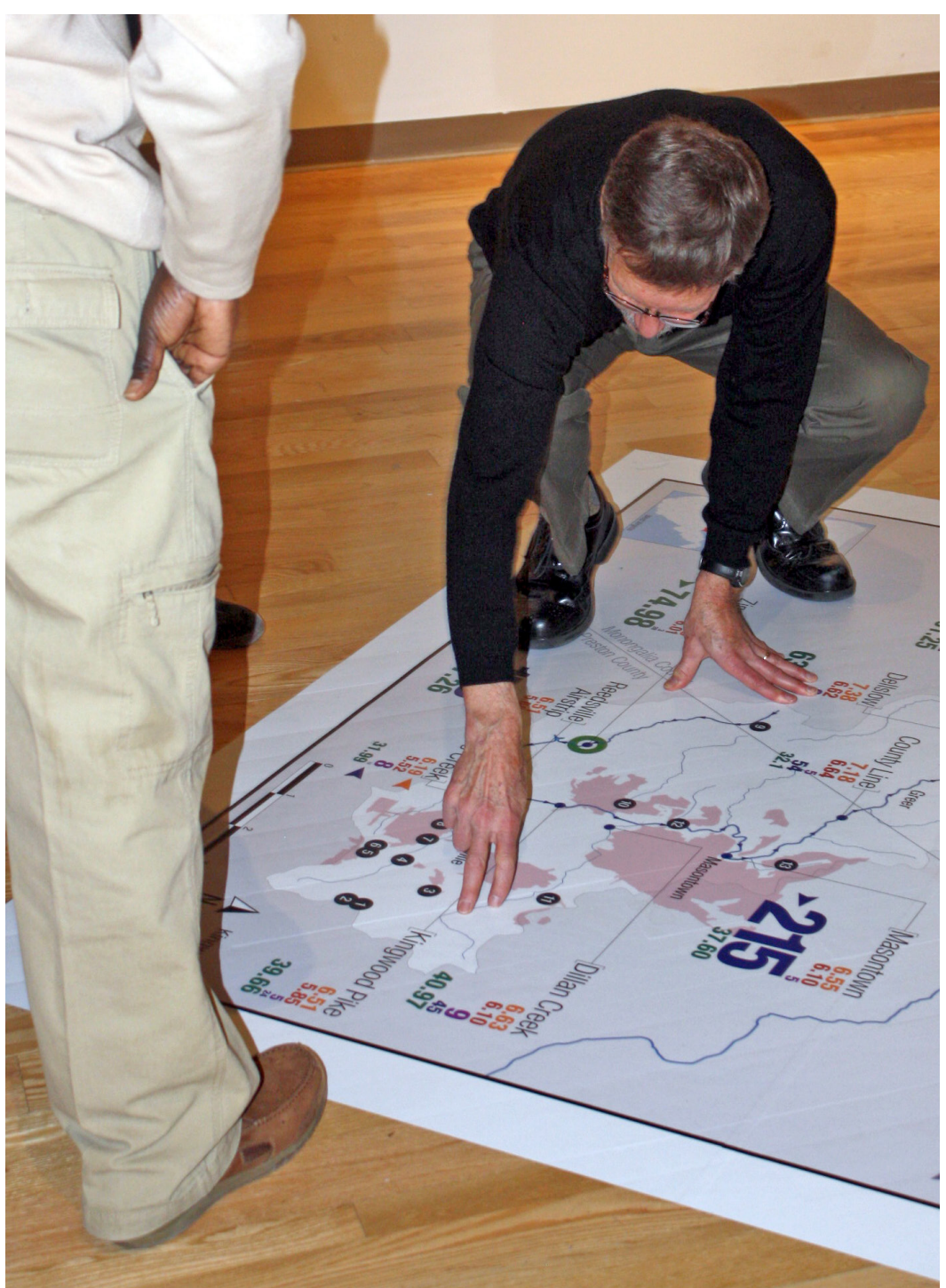

Figure 5.24: FODC board member and citizen scientist detailing important aspects of the Deckers Creek Watershed.

discovery. As designers, we are communicators, narrative builders, and facilitators. Entertainment becomes an immersive method of education that helps to empower a community. This empowerment becomes a catalyst for action. 


\section{CONCLUSION}

The difference between traditional methods of problem solving and a transdisciplinary approach begins with the task of defining the complex nature of the problem. This definition includes the social, emotional, and cultural implications of the problem to present a more holistic strategy. Because societal issues are often complex and multidimensional, the definition itself might differ from how one or more disciplines would define the problem. The definition becomes limited because it exists within the confined scope of a particular discipline.

With a transdisciplinary approach, disciplines are employed as the definition becomes clearer. Where traditional processes begin with chosen disciplines creating solutions "for" the stakeholders involved, a transdisciplinary approach puts more emphasis on designing "with." With a trans-approach, solutions evolve more organically and are more likely to cross cultural divides. These solutions are able to navigate these cultural obstacles because stakeholders are invested at a project's infancy and the designed solution is centered around their personal cultures.

With these more collaborative methods, cultural change happens throughout the process and not simply as a result of the solution. By these methods, stakeholders become advocates of the solution and design solutions become memorable and help to speak the cultural language of the audience it serves.
Collaborative methods such as these, have been termed co-design or humancentered design methods and with their implementation, stakeholders become advocates for the process as well.

These methods help to advance the field of design as a profession, and brings designers into roles of facilitators, strategists, and leaders. As designers, we must become diligent advocates for design throughout our respective organizations and communities. While a transdisciplinary approach can gain proponents gradually from project to project, we must look towards changing educational and corporate structures as well. As design educators, we can begin by building team environments that span disciplines and departmental boundaries. Projects and programs that focus on "realworld" applications and experiences out of the classroom create a deeper base knowledge for students that help prepare them for their careers as professional designers.

Transdisciplinary experiences are also important for non-design professions because it prepares employees for a collaborative and professional workplace. More importantly, it helps them to build the skills to translate the language of multiple disciplines creatively. 


\section{BIBLIOGRAPHY}

Nicolescu, Basarab. "The Transdisciplinary Evolution of Learning." (Talk at the American Educational Research Association (AERA), Annual Meeting, Montréal, Canada, April 1999, Round-Table) Basarab Nicolescu. Accessed April 26, 2014. http://basarabnicolescu.fr/Docs_articles/AERA_April_1999.pdf.

"Understanding Wicked Problems," ac4d: Austin Center for Design, Accessed May 13, 2004. http://www.ac4d.com/home/philosophy/understanding-wicked-problems,

Brown, Tim. "On Being T-Shaped," Hack 2 Work, Essential Tips for the Design Professional, September 2009, Accessed April 26, 2014, http://www.core77.com/ hack2work/2009/09/on_being_tshaped.asp.

Brown, Tim. Interview by Morten T. Hansen, January 21, 2010, "IDEO CEO Tim Brown: T-Shaped Stars: The Backbone of IDEO's Collaborative Culture," Chief Executive. net, Accessed April 26, 2014. http://chiefexecutive.net/ideo-ceo-tim-brown-tshaped-stars-the-backbone-of-ideoae\%E2\%84\%A2s-collaborative-culture.

"CIRET, CENTRE INTERNATIONAL DE RECHERCHES ET ÉTUDES TRANSDISCIPLINAIRES," Le Projet Moral 1987, Last modified on : Saturday, October 202012 12:11:49, Accessed April 26, 2014. http://ciret-transdisciplinarity. org/moral_project.php.

Sanders, Elizabeth. "Stepping Stones Across The Gap, Explorations in the Generative Design Space," essay, Reprinted from Halse, J., Brandt, E., Clark, B. and Binder, T. (Eds.) Rehearsing the Future, The Danish Design School Press, 2010, Accessed April 26, 2014. http://www.maketools.com/articles-press/rtf.pdf.

Friends of Deckers Creek, "History," Accessed April 27, 2014. http://www.deckerscreek. org/about/history.

"About Friends of Deckers Creek," Friends of Deckers Creek, Accessed April 27, 2014. http://www.deckerscreek.org/about/history.

Snyder, Gary, "Preface," in No Nature: New and Selected Poems. (New York and San Francisco, Pantheon Books, 1992).

Spencer, Malia, "Full STEAM ahead: As STEM discussions heat up, there is a growing desire to add an 'A' for art," Pittsburgh Business Times, Updated: August 16, 2012, Accessed April 27, 2014. http://www.bizjournals.com/pittsburgh/print-edition/2012/08/17/ full-steam-ahead-as-stem-discussions.html?page=all.

Kolko, Jon, Wicked Problems: Problems Worth Solving, ac4d: Austin Center for Design, Jon Kolko, 2012.

Kelley, Tom and David. "Why Designers Need Empathy," The Eye: Slate's Design Blog, Slate, November 8, 2013, 11:02 a.m., Accessed April 27, 2014. http://www.slate.com/ blogs/the_eye/2013/11/08/empathize_with_your_end_user_creative_confidence_ by_tom_and_david_kelley.html.

Friends of Deckers Creek, Accessed April 11, 2011. "Be a Watershed Watchdog," www. deckerscreek.org.

United States Environmental Protection Agency, "What is a Watershed?" Accessed April 26, 2014. http://water.epa.gov/type/watersheds/whatis.cfm, updated March 6, 2012.

IBM Creek Watch Application, "Creek Watch: Explore Your Watershed," Accessed April 27, 2014. http://creekwatch.researchlabs.ibm.com. 


\section{BIBLIOGRAPHY}

SeeClickFix, "How it Works," Accessed April 27, 2014. http://en.seeclickfix.com/how-itworks.

Sierra Club, "Take Action," Accessed April 27, 2014. http://action.sierraclub.org/site/ PageServer?pagename=TakeAction\&s_src=610ZSCAC01.

United States Environmental Protection Agency, "Waters: My WATERS Mapper," Accessed April 27, 2014. http://watersgeo.epa.gov/mwm/.

Appalachian Stewardship Foundation, Accessed April 27, 2014. http://appalachianstewards.org/.

Friends of Deckers Creek, post to Friends of Deckers Creek Facebook page, February 6, 2014 (5:17 p.m.), Accessed April 27, 2014. https://www.facebook.com/ friendsofdeckers/posts/675388689166633.

CAPTCHA, "CAPTCHA: Telling Humans and Computers Apart Automatically," Accessed April 27, 2014. http://www.captcha.net/.

Merriam-Webster.com. "Watershed." Accessed November 16, 2013. www.merriamwebster.com/dictionary/watershed.

American Whitewater, www.americanwhitewater.org, Deckers Creek, West Virginia, US: Preston Co. line (Upper - Cascades), Accessed May 8, 2014. https://www. americanwhitewater.org/content/River/detail/id/2894/.

United States Environmental Protection Agency, "Overview," Deckers Creek, National Pollutant Discharge Elimination System (NPDES), Last Updated March 12, 2009, Accessed May 15, 2014. http://cfpub.epa.gov/npdes/.

Denicola, Timothy. FODC Project Manager, e-mail message to author, March 18, 2014.

BOPARC: Board of Park and Recreation Commission, "Marilla Park Information." Parks \& Trails, Accessed April 26, 2014. http://www.boparc.org/marilla-park.html.

Maclean, Norman. A River Runs Through It and Other Stories. (PLACE, PUBLISHER, YEAR).

NASA Earth Observatory, Astronaut photograph AS17-148-22727, African Continent, Blue Marble, Apollo 17 Crew, acquired December 7, 1972, Apollo - 70mm Camera, Accessed May 15, 2014. http://earthobservatory.nasa.gov/IOTD/view.php?id=1133.

Mon River Trails Conservancy, "Maps: Deckers Creek Trail," Accessed May 15, 2014. http:// www.montrails.org/maps.shtml.

City As Living Laboratory, Framework for a 21st Century City, Sustainablitiy Made Tangible Through The Arts, "FLOW Can You See the River?," Accesed May 15, 2014. http:// flowcanyouseetheriver.org.

Snodgrass, Susan. "Mary Miss Goes With the Flow," Art in America, News, (September 23, 2011), Accessed May 15, 2014. http://www.artinamericamagazine.com/newsfeatures/news/mary-miss-fairbanks-art-and-nature-park.

Anderson, Stacey. "Mary Miss:Flow," September 21, 2012, YouTube, Accessed May 15, 2014. http://youtu.be/rCkTZmXR2Nk

Indianapolis Museum of Art, "FLOW: Can you See the River?", YouTube, Uploaded October 4, 2011, Accessed May 15, 2014. http://youtu.be/7mJoYbxsCIY.

Chang, Candy. Before I Die, 2011, New Orleans, Accessed May 15, 2014. http://candychang. 


\section{BIBLIOGRAPHY}

com/before-i-die-in-nola,.

Chang, Candy. TED Speaker, TED: Ideas worth spreading, Accessed May 15, 2014. http:// www.ted.com/speakers/candy_chang.

Chang, Candy. "Candy Chang: Before I die I want to..." (video of lecture, TEDGlobal 2012, Edinburgh, Scotland, Filmed July 2012), Accessed May 15, 2014. http://www.ted. com/talks/candy_chang_before_i_die_i_want_to/transcript, 4:04 minutes.

No Injection Well, "Home," Accessed May 11, 2014. http://noinjectionwell.org.

Beard, David. "Energy Corp. scraps Masontown well plans, The Dominion Post, April 18, 2014, Accessed April 19, 2014. http://thedpost.com/Energy-Corp--scraps-Ma-sontown.

Tufte, Edward R. The Visual Display of Quantitative Information, Epilogue: Designs for the Display of Information, (Cheshire, Connecticut: Graphics Press, 2001),191.

University of Wisconsin, USEPA:Pollution Prevention/Good Housekeeping for Municipal Operations, National Menu of Best Management Practices Fact Sheets, University of Wisconsin, Accessed May 15, 2014. http://www3.uwm.edu/Dept/shwec/ publications/cabinet/other/EPAMunicipalSWP2BMPs.pdf.

Rodin, Auguste. The Thinker, 1903, Musée Rodin, Paris, France.

United States Environmental Protection Agency. "What is Nonpoint Source Pollution?," Water: Polluted Runoff, Accessed May 15, 2014. http://water.epa.gov/polwaste/nps/ whatis.cfm.

Hacker, Kenneth. Morgantown Utility Board, e-mail message to author, Monday, December 2, 2013 .

United States Environmental Protection Agency. Abandoned Mine Drainage, Water: Polluted Runoff, Accesssed May 15, 2014. http://water.epa.gov/polwaste/nps/acid_mine. cfm\#info.

Friends of Deckers Creek. Acid Mine Drainage, Projects, Accessed May 15, 2014. http:// www.deckerscreek.org/about/projects/acid-mine-drainage.

Schrecongost, Alyse and Evan Hansen. "Local Economic Benefits of Restoring Deckers Creek: A Preliminary Analysis," Friends of Deckers Creek, August 2005,

Publications, Accessed May 15, 2014. http://www.deckerscreek.org/images/stories/ pdf/DeckersEconomicAnalysis.pdf.

Tundra Endeavour. Accessed May 15, 2014. http://www.toyota.com/tundraendeavour.

Friends of Deckers Creek. "Friends of Deckers Creek Hosts Community Meeting to Promote Richard Mine Project," News and Events, Friends of Deckers Creek, Accessed June 21, 2014. http://deckerscreek.org/.

Talotta, Lauren. "Friends of Deckers Creek Proposes Water Treatment Plant to Prevent Acid Mine Drainage," WBOY 12 News, June 18, 2014, Accessed June 21, 2014. http://www.wboy.com/story/25804257/friends-of-deckers-creek-proposes-watertreatment-plant-to-prevent-acid-mine-drainage.

Tomlinson, Eric. "Richard Mine Drainage Public Meeting 6-17-2014," (video) The Dominion Post, June 17, 2014. Accessed June 21, 2014. http://www.youtube.com/ watch?v=IY4yVhjSCUU. 


\section{BIBLIOGRAPHY}

The Dominion Post. Friends of Deckers Creek, "FODC honored for Adopt-A-Highway work," The DPost Blogs, September 10, 2013. Accessed May 15, 2014.

Lattea, Charlene. "First new Steinway piano arrives at WVU," WVUToday, West Virginia University, Creative Arts Center, December 15th, 2011. Accessed May 15, 2014. http://wvutoday.wvu.edu/n/2011/12/15/first-new-steinway-piano-arrives-at-wvucreative-arts-center\#sthash.9hpaovS1.dpuf College of Creative Arts.

Action Research. "Littering Behavior in America: Results of a National Study," January, 2009, Prepared for Keep America Beautiful. Accessed May 15, 2014. http://www. kab.org/site/DocServer/KAB_Report_Final_2.pdf?doclD=4581.

Ocean Conservancy. "Tracking Trash: 25 Years of Action for the Ocean," 2011 Marine Debris Report. Accessed May 15, 2014. http://act.oceanconservancy.org/pdf/ Marine_Debris_2011_Report_OC.pdf.

Register, Kathleen. "Cigarette Butts as Litter - Toxic as Well as Ugly?," Underwater Naturalist, Bulletin of the American Littoral Society, Volume 25, Number 2, August 2000. Accessed May 15, 2014. http://www.cigarettelitter.org/index.asp?pagename=un.

Christ, M.J. The State of the Creek, 2005: The Clean Creek Program Annual Report, "State of the Creek, 2005," April 2006, Friends of Deckers Creek, Dellslow, West Virginia. Accessed May 15, 2014. http://www.deckerscreek.org/images/stories/pdf/Friends\%20of\%20 Deckers\%20Creek\%20State\%20of\%20the\%20Creek\%202005.pdf.

Friends of Deckers Creek, "Clean Creek Program," Projects, Accessed May 15, 2014. http:// www.deckerscreek.org/about/projects/clean-creek-program-sponsors.

West Virginia Department of Environmental Protection. "West Virginia Stream Condition Index (WVSCI)," Benthic Macroinvertebrate sampling and data, State of West Virginia 2014. Accessed May 15, 2014. http://www.dep.wv.gov/wwe/watershed/ bio_fish/pages/bio_fish.aspx.

West Virginia Department of Environmental Protection Division of Water and Waste Management. "2010 West Virginia Integrated Water Quality Monitoring and Assessment Report." Accessed May 15, 2014, 13. http://www.dep.wv.gov/WWE/ Programs/nonptsource/WBP/Documents/2010IR.pdf.

West Virginia Department of Environmental Protection, Office of Oil and Gas, "Water Management Plans," State of West Virginia 2014, accessed May 15, 2014, http:// www.dep.wv.gov/oil-and-gas/Water\%20Management/Pages/default.aspx, (Posted December 7, 2011)

Ziemkiewicz, Paul, Hause, Jennifer, Gutta, Brady, Fillhart, Jason, Mack, Ben, and O'Neal, Melissa, West Virginia Water Research Institute, Final Report: Water Quality Literature Review and Field Monitoring of Active Shale Gas Wells, Phase I, Assessing Environmental Impacts of Horizontal Gas Well Drilling Operations, Prepared for West Virginia Department of Environmental Protection, Division of Air Quality, (West Virginia University, February 15, 2013), accessed May 15, 2014, http://www.dep.wv.gov/oiland-gas/Horizontal-Permits/legislativestudies/Documents/Water\%20Report\%20 Phase\%201\%20submitted\%20Feb\%2020,\%202013.pdf 